Historic, Archive Document

Do not assume content reflects current scientific knowledge, policies, or practices. 



\section{7}

\section{WILSON S. BROWER \\ COMPANY, INCORPORATED \\ SUCCESSORS TO \\ MUZZY BROTHERS}

son.

\section{Superior Seeds, Implements}

Bulbs and Plants

\section{VAN HOUTEN STREET PATERSON, N. J.}

Estublished 1835

$\therefore \quad$ SHerwood 2.1388
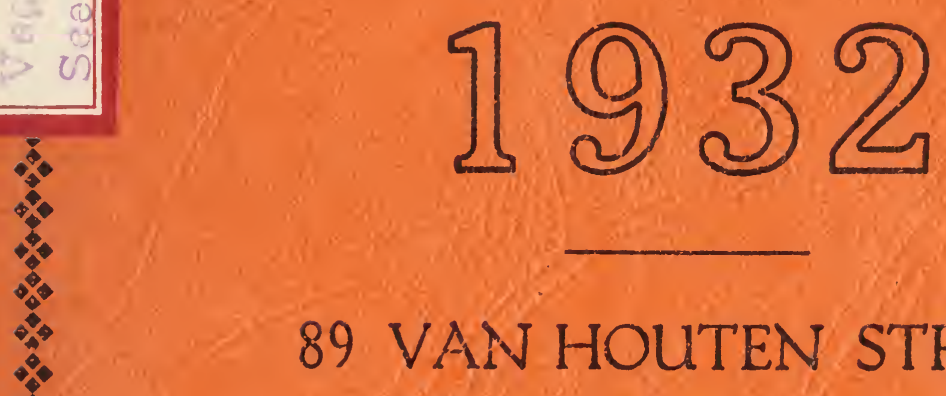

*

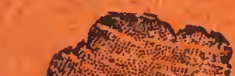

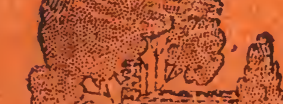

6

6 (6)

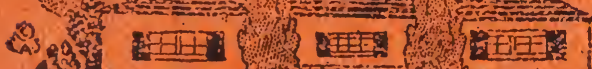

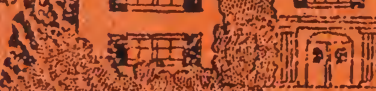

ate

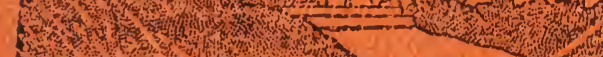

(8)

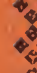

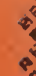

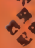

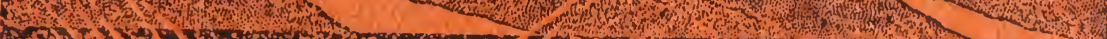

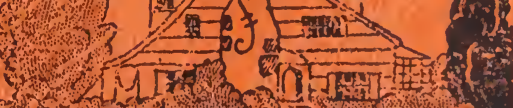

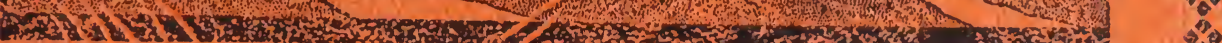

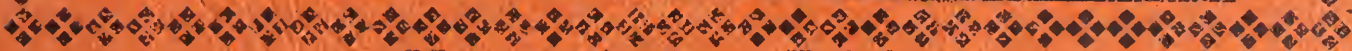
$\checkmark$ goetalise seod Trials 


\title{
SPECIAL NOTICE
}

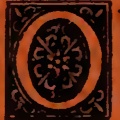

UR Aim is to sell the Best Seeds Obtainable.

We give no warranty, expressed or implied as to description, purity, quality, productiveness, or any other matter of any seeds, bulbs or plants we sell, and we will not in any way be responsible for the crop. If the purchaser does not accept the goods on these terms they are to be returned, and money refunded.

WILSON S. BROWER COMPANY, Inc. Successors to

\section{MUZZY BROTHERS}

\author{
SEED AND AGRICULTURAL WAREHOUSE \\ 89 Van Houten Street \\ Paterson, N. J.
}

PRICES SUBJECT TO CHANGES WTHOU'T NOTICE

\section{Special Notice to Market Gardeners}

Wo sell to Market Gardeners, Truckers and Farmers' Clubs at special wholesale rates, and solicit your inquiries for close prices on round lots.

QUANTIT OF SEEDS FOR A GIVEN NUMBER OF PIANTS, ETC.

Asparagus

Beet

Carrot

Endive

Okra

Onion

Onion Sets, small

Parsley

Parsnip

Radish

Salsify

Spinach

Turnip

Peas

Dwarf Peas
$1 \mathrm{oz}$. to $60 \mathrm{ft}$. drill

$1 \mathrm{oz}$. to $50 \mathrm{ft}$. drill

$1 \mathrm{oz}$. to $150 \mathrm{ft}$. drill

$1 \mathrm{oz}$. to $150 \mathrm{ft}$. drill

$1 \mathrm{oz}$. to $40 \mathrm{ft}$. drill

$1 \mathrm{oz}$. to $100 \mathrm{ft}$. drill

$1 \mathrm{oz}$. to $20 \mathrm{ft}$. driil

$1 \mathrm{oz}$. to $150 \mathrm{ft}$. drill

$1 \mathrm{oz}$. to $200 \mathrm{ft}$. drill

$1 \mathrm{oz}$. to $100 \mathrm{ft}$. drill

$1 \mathrm{oz}$. to $70 \mathrm{ft}$. arill

$1 \mathrm{oz}$. to $100 \mathrm{ft}$. dri!l

$1 \mathrm{oz}$. to $150 \mathrm{ft}$. drisl

1 qt. to $100 \mathrm{ft}$. drill

...1 qt. to $100 \mathrm{ft}$. drill
Pole Beans

1 qt. to 150 hills

Corn .

Cucumber

Water Melon

Musk Melon

Pumpkin

Early Squash

Marrow Squash

Cabbage

1 qt. to 200 hills

$1 \mathrm{oz}$. to $50 \mathrm{hills}$ $\ldots . .1 \mathrm{oz}$, to 30 hil's $1 \mathrm{oz}$. to $60 \mathrm{hills}$ oz. to 40 hills $1 \mathrm{oz}$. to 50 hills $1 \mathrm{oz}$. to 16 hills

Cauliflower

Celery

Esg Plant

Lettuce

Pepper

Tomato $1 \mathrm{oz}$. to 3,000 plants $1 \mathrm{oz}$. to 3,000 plants $1 \mathrm{oz}$. to 4,000 plants $.1 \mathrm{oz}$. to 2,000 plants 1 oz. to 4,000 plants $.1 \mathrm{cz}$. to 2,000 plants $.1 \mathrm{oz}$. to $2,0 \mathrm{CO}$ plants 


\section{How \\ To Make \\ A \\ Lawn}

The production of a good lawn is made by the following method: (1) When the soil is moist dig it up about 6 " deep; if the ground is "muddy" allow a few days of clear weather to dry it up. (2) As you dig lift each clod high enough to enable you to turn it completely over. (3) Now break and pulveiize the inverted clod with the black of the fork. (4) Remove from the plot all stones, sticks etc. (5) Scatter Hyper-Humus on the dug earth, use $100 \mathrm{lbs}$. to every 60 square feet. (6) Draw our "speedy" cultivator or a rake back and forth over the whole plot until the soil is in a fine condition. (7) Purchase
"Velvet" Lawn Seed at the minimum rate of 1 lb. per 400 square feet, plot $20 \times 20$, or double the quantity when the lawn is needed quickly or a very thick turf desired. Divide the seed in two equal parts and sow on a calm day. going over the whole area twice, the second time at right angles to the first. (8) Rake the plot again very lightly. This time drawing the rake toward you in a series of ight strokes, raking only once in the same place. Grass seed should not be covered more than one-eighth of an inch. (9) Roll (or pat with the back of a spade) the area planted when dry.

\section{OUR LAWN SEED MIXTURES}
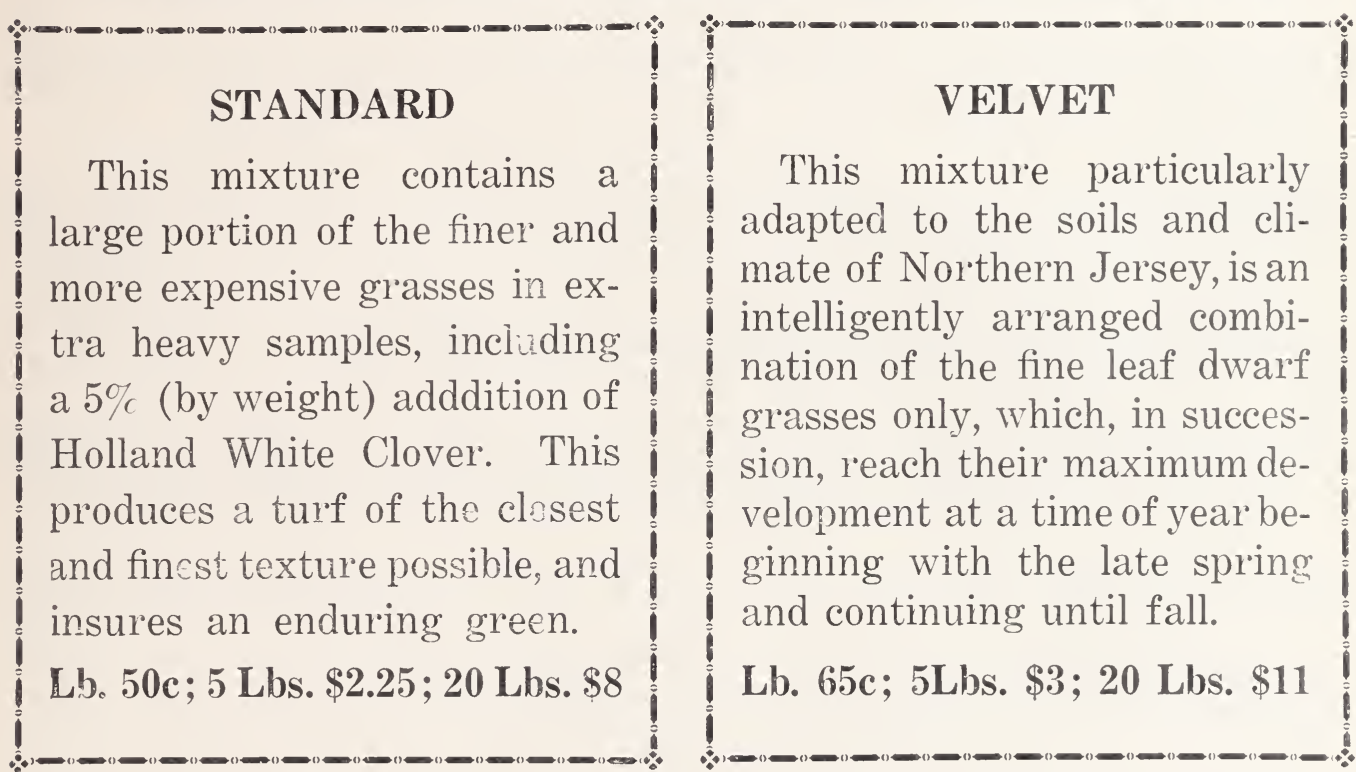

This mixture particularly i adapted to the soils and cli- i mate of Northern Jersey, is an intelligently arranged combination of the fine leaf dwarf grasses only, which, in succession, reach their maximum development at a time of year beginning with the late spring and continuing until fall.

Lb. 65c; 5Lbs. $\$ 3 ; 20$ Lbs. $\$ 11$ i.

.




\section{GRASS SEED}

In Separate Varieties

It is our intention in giving the separate varieties of grass seeds as listed below to familiarize one with the character of the individual varieties and we do not think it advisable to plant any one variety in place of a mixture. We obtain these individual grass seeds direct from the best original sources which we have discovered in our many years of experience to be botanically true, new crop seed, re-cleaned, and of the highest degree of purity and germination.

THE BENTS (Agrostis Species). All bents are slow starting in the spring but as they do not mature until late summer their color is carried in late fall. The seeds are the smallest of the lawn grass seeds $(8,000,000$ per pound) and produce the finest textured turf.

German Bent (A. stolonifera varieties). This is a natural bent seed mixture produced in Germany and sold as German Bent or South German Creeping Bent and ordinarily contains Red Top, Velvet Bent and Creeping Bent. The sod produced by this mixture tolerates very close mowing and makes an excellent turf when properly top-dressed to prevent matting of the stolens at the surface.

Rhode Island Bent (A. tenuis, A. vulgaris). This seed was imported from England during the eighteenth century. It has become naturalized and is now found growing wild all over the northern half of the United States and Southern Canada. There are many strains of this variety: A Colonial Bent or Brown-top from New Zealand, and others from Rhode Island, Washington State and Prince Edward Isle. It is very resistant to drought, withstands very close mowing and has proven aggressive on all but the poorest soils.

Redtop (Agrostis palustris). Redtop makes a rapid growth when newly seeded, the sod formed is tought but does not stand close clipping, becoming coarse and stubby and seldom remains in a lawn more than a year and a half. Because of the poor texture of the sod the grass should be used primarily in mixtures with Kentucky Blue Grass and other varieties.

THE BLUE GRASSES (Poa Species). The seed of the blue grass is small, averaging 2400,000 to a pound. They prefer an alkaline soil, are slow to germinate, and their leaves are distinguished with the exception of Poa trivialis, by their upright growth.

Kentucky Blue Grass (P. pratensis). This variety is one of the best species of seed for lawns in New Jersey; it is aggretssive, thrives on loamy soils and is not fully developed until the end of the second year from planting. The sod is not permanently injured by drought or high temperatures. It grows best when mixed with other seeds, and is used as a basis in all of the better mixtures of seeds.

Canada Blue (P. compressa). This variety is closely associated with the Kentucky Blue. Its use is confined to very poor clay soils and graveled knolls or as a soil binder on silt. It forms an open coarse texture sod and the color js an undesirable slaty bluish green.

Rough Stalked Meadow Grass, or Bird Grass (P. trivialis). This variety can hardly be distinguished from the Kentucky Blue, and should be used as a substitute on all shaded or partly shaded and damp locations.

Wood Meadow (P. nemoralis). This variety has proved to be a weak grower unable to compete with other grasses and weeds. The sod produced is coarse and open. This variety is of value in Europe but does not thrive? ere. 
THE FESCLES (Festuca Species). The fescues are not particular as to their soil reaction, except Red Fescue, which appears a little more satisfied on acid soil than alkaline. The seeds are large, about 600,000 to the pound, and thrive best on poor sandy soils.

Sheeps Fescue (F. ovina). This variety has tough wiry foliage and they make vigorous growth only in cool weather. It is able to survive on very poor and sandy soils, however, there is no place in a lawn but does make an excellent rough on the golf course.

Hard Fescue (F. durinshcula). Fine leaved fescue differs from Sheep's Fescue in having somewhat finer foliage, but both grasses have a similar adaptation.

Red Fescue (F. rubra). Genuine Red Fescue is stoleniferous on sandy loam. If seeded alone it will produce a thick drought-withstanding turf practically free from weeds. The texture is wire-like and somewhat difficult to mow. When closely cut to a height of one-quarter inch, red fescue languishes in hot weather.

('hewing's N. Z. Fescue (Festuca rubra fallax) On loamy soils, Chewing's fescue makes fairly good growth but it does not form a smooth sod and lacks the ability to spread and heal injuries. Perhaps the best use of this plant is for turf on soils which are too sandy or lacking in fertility to upport Kentucky bluegrass. The foliage is very tough and withstands much hard usage without apparent injury. but it is also difficult to cut and blends poorly with the bent grasses and Kentucky bluegrass.

Ieadow Fescue (F. pratensis). This species differs in that the leaves are flat, broad and very glossy on the underside. It is adapted to wet soil where it makes a very quick growth. There is little advantage in using this species for ordinary locations but adapts itself to shade and therefore is of value in shady mixtures.

THE RVES (Lolium Species). Rye grasses are quick germinating and fast growing; for this reason they are used for cover or nurse crop. The seeds are very large, 220,000 to the pound.

Perennial Rye (L. perenne). This species is a short-lived perennial in lawns and is used primarily for a quick production of green coverings on newly seeded areas. The turf rarely becomes as finely knitted as the bents or Poa Species and is rarely seeded alone.

Italian Rye (L. multifolium). Although seedlings of rye grass will grow nearly three times as fast as those of other species it is shorter lived and usually succumbs to hot, dry weather. It is suitable only for making a temporary turf' in fall or early spring.

Domestic Rye is an American grown perennial rye, whose life in turf is only one year, or possibly two growing seasons.

OTHER YORTHERN GRASSES. In general these grasses are used for rough and other coarse turfs where the soil is usually less fertile and more likely to be neglected and where the finer turf is not desired. The seeds listed below are less expensive and if mowing is not required regularly they will not make too dense a growth.

Timothy (Phleum pratense). A species of inexpensive seed well adapted to this climate, a wide range of soils, and a good appearance of grass comparatively easy to obtain.

Orchard Grass (Dactylys glomerata). This species is one of the most shade-loving grasses available for this climate, and is somewhat better adapted to sandy soil than Timothy.

Tall Oat Grass (Arrhenatherum elatius). This grass may be employed to good advantage on poor or gravelly soils, but does not tolerate frequent close cutting. It is not so persistent in this climate as are timothy and orchard grass, and is distinctly a bunch grass, unsuited for fine turf.

Sweet Vernal Gras (Anthoxanthum odoratum). This grass makes a very early growth in spring and has been found to be tolerant of poor or droughty soils. It forms a bunchy sod, but, like orchard grass, tolerates fairly close cutting.

White Clover ('Trifolium repens). This familiar plant is much used for lawns. It grows quickly forms a green herbage and remains green throughout the season. The addition of bone meal or lime to the soil is a great benefit to it. 


\section{MERITORIOUS VARIETIES}

\section{FOR 1932

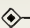

\section{SQUASH}

GLANT YELLOW SUMUER STRAIGHT NECK SQUASH. A recent selection from the Giant Yellow Summer Crook Neck Squash with all the good qualities of the former and none of its defects. There will be found in the new strain a small percentage that are not Crook Necks or Giant. The squashes are a deep or ange color, heavily warted and when mature measure from 15 to 18 inches in length. The flesh is thicker and more meaty in the neck than in the Crook Neck variety. Pkt. 10 cts., oz. 20 cts., $1 / 4$ lb. 50 cts., lb. $\$ 1.75$.

NEAPOLITAN SQUASH grows very long and slender, quite heavily curved, often scimitar in shape. The color is light green with smooth surface. It runs three to four inches in diameter, in fact, this Squash reminds one of an eel. Oz. 75 cts., 4 oz. $\$ 2.75$.

\section{GREEN BEANS}

ISGROW VALENTINE BEANS. After many years of careful breeding and selection we are able to offer a Black Valentine which is stringlss. It is hardy, productive, and the long green pods are fairly straight and entirely stringless. We only have these in limited quantity this year, but all bean growers for market should give it a trial. Pkt. $20 \mathrm{cts}$., $1 / 2 \mathrm{lb}$. 40 cts., lb. 70 cts., 2 lbs. $\$ 1.30,4$ lbs. $\$ 2.50,10$ lbs. $\$ 5.00$.

\section{TOMATO}

MARGLOBE. A new variety developed by the United States Department of Agriculture. Is very wilt resistant and is resistant to nail head rust. Fruit resembles Livingston's Globe but is scarlet and the flesh more solid. Vine dark green and vigorous. 4 oz. $75 \mathrm{cts} ., 1 \mathrm{lb}$. $\$ 2.00$.

\section{ONION}

THE BARLETTA ONION is a white small type, semi-flat, and is grown largely for pickling purposes. As it is medium early, it could be also used for an early garden Onion. Oz., 40c; 4 oz., $\$ 1.15 ; 1$ lb., $\$ 3.50$.

\section{BEETS}

EARLY WONDER. Roots are of globe shape with small top and the color of the fiesh is deep blood red slightly zoned. Quality is excel'ent. May be used for both early and late plantings. 1 oz., $15 \mathrm{c} ; 4$ oz., $40 \mathrm{c} ; 1$ lb., $\$ 1.25$.

\section{PUMPKIN}

CHEESE. This is an unusually fine straight grown exclusively for the most critical trade. A very large, flat ribbed fruit, of a beautiful buff yellow color; the interior is of fine quality. Oz., 25c; $1 / 4$ lb., $75 \mathrm{c}$.

\section{CELERY}

GOLDEN KING. Grows about 24 to 26 inches in height; long jointed; 8 or 9 inches to the joint; long rib, good heart, faster grower, making a very desirable strain for an extra early crop. It branches in 10 to 12 days. Pkt., $25 \mathrm{c} ; 1$ oz., $\$ 2.00 ; 1 / 41 \mathrm{~b} ., \$ 7.00$.

\section{SWEET CORN}

SPANISH GOLD EARLY. A new variety of sweet corn, ripens early, produces many good sized ears and among the first to give marketable ears which are well filled to the tips with 10 to 12 straight rows of bright yellow kernels. 1 lb., $65 \mathrm{c} ; 5$ lbs., $\$ 3.00$. 


\section{7th Year}

\section{Wilson S. Brower \\ Company, Incorporated}

SUCCESSORS TO

MUZZY BROTHERS

\section{Vegetable Seeds 1932}

\section{ARTICHOKE}

German, Artichoke; French, Artichaut; Spanish, Albachofa.

French Globe

The seeds should be sown in the spring, in drills an inch and a half deep, and one foot apart. The next spring transplant to permanent beds, in rows or hills three feet apart and two feet between the plants. Plant in a deep rich, moist loam, and the plants should be protected in winter by a covering of leaves or coarse manure. A bed will continue bearing for several years. Jerusalem Articholie, Tubers 25 cents each

\section{ASPARAGUS \\ German, Spargel; French, Asperge; Spanish, Esparrago.}

Plit, 5 Cents

lonover's Colossal

$\begin{array}{ccr}\text { Per oz. } & 1 / 4 \mathrm{lb} . & \text { Per } 1 \mathrm{~h} . \\ .15 & .40 & 100 \\ .15 & .45 & 125 \\ \text { Per } & \text { Per } & \text { Per } \\ 50 & 100 & 1000 \\ 1.00 & 1.50 & 12.50 \\ 1.75 & 3.00 & 23.00\end{array}$

P'almetto, a light green variety _.......................................................................................................... $.15 \quad .45 \quad 125$

ROOTS

Ruots Palmetto, 2 years

1.75

$1.50 \quad 12.50$

Roots Iary Washington 2 years

Sow the seeds early in spring, in drills 15 inches apart, and about a dozen to the foot in the drill; keep the soil mellow and free from weeds during the summer, and in the succeeding spring transplant to permanent beds which should be done in the following manner as described by a cultivator of Oyster Bay Asparagus.

Plant on sandy soil. To grow Asparagus in perfection, the soil need not necessarily be richer than it must be to produce a good crop of corn. Some experiments have shown that by heavily manuring the crop cannot be made permanenily greater than by moderate dressings. It is no: desirable to plant them out very earlly: more plants will fail to grow than when the planting is deferred until the soil is dry and warm.

In planting for private use: set out in rows two feet apart, and allow twelve inches in the row. Set the plants at least six inches below the surface. For market on a large scale set four feet apart one way and two the other, which will allow the use of a horse and cultivator to keep the weeds under. 


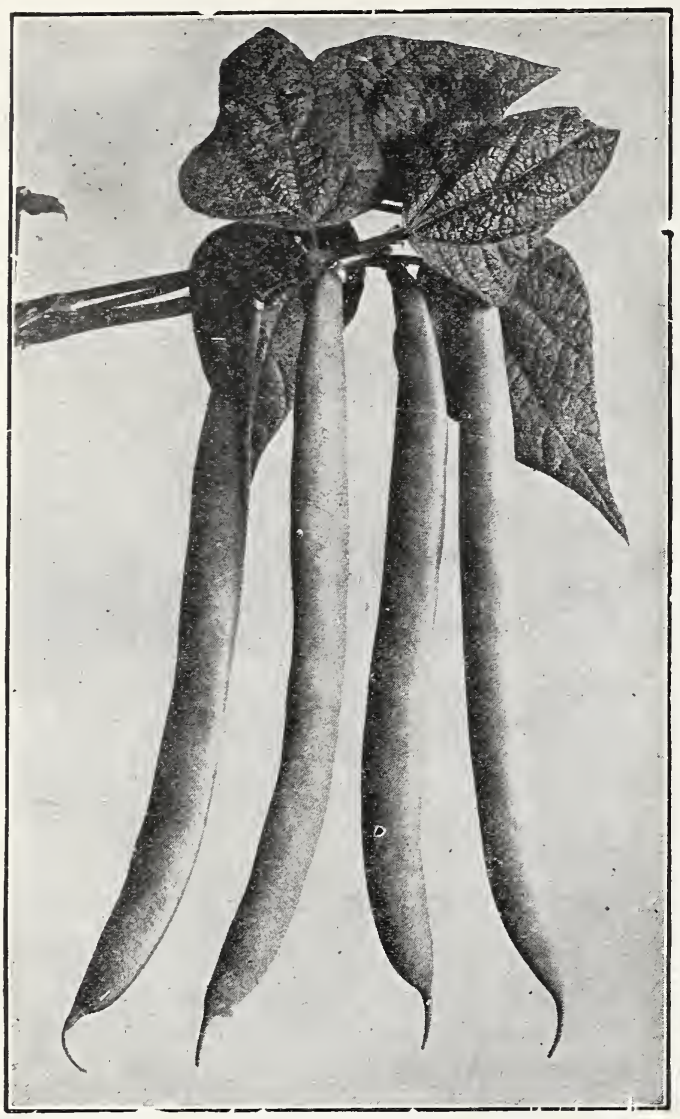

\section{BEANS}

German, Gartenbohne; French, Feve de Marais; Spanish, Hava,

English or Broad.

\section{String Beans}

Dwari or Bush Green Podded Varieties

All Green String Beans, 40c. 1b.; 2 Ib., 75c.

Asgrow Valentine, a Black Valentine which is stringless, hardy, productive and long green pods fairly straight and entirely stringless. All bean growers should give it a trial.

Bountiful Extra Early. Very prolific and long bearing. Flat green pods, tender and stringless.

Valentine Black, long round, green, solid pod, very early.

Valentine Giant Stringless, about seven days later than extra Early Valentine. Slightly curved pod, brittle and stringless; a strong grower and good yielder.

Valentine Early. Productive, tender and of excellent flavor.

Burpee's Stringless Green Pod, the best stringless bean grown. Ten days to two weeks earlier than the Valentine; pods full and fleshy, extremely crisp and absolutely stringless. Very productive.

Refugee or Thousand to One. (Late variety.) The pods are round and full, stringless and of fine quality.

\section{DWARF WAX VARIETIES}

All wax string beans, 40c. lb.; 2 lbs., 75c.

Delicious Wax, Landreths-54 Days. This is a splendid, very productive, round podded Wax Bean, with extremely healthy vines. This Stock was selected very carefully from Stringless Green Pod in our Trial Ground at Filer, Idaho. It is the same in every respect as the Stringless Green Pod except that the Pod is a Wax instead of a Green Pod. This bean should supersede the Improved Golden Wax as it is a much better quality. The pods are round and absolutely stringless. The dry Seed being identical in appearance to the Stringless Green Pod. All Dwarf Wax Varieties, 1 lb., 40c; 2 lbs., $75 \mathrm{c}$.

Sure Crop Stringless Wax, It starts bearing within 60 days after seeds are sown. The pods average 6 to 7 inches long, are very meaty, fiat but thick through, and in common with most black-seeded varieties, is very hardy and may therefore be planted several days earlier than the light-seeded sorts.

Round Pod Kidney Wax, same as Wardell's, only round pods.

Wardell's Kidney Wax, extra early, long flat pods, very productive.

Golden Eyed Wax Earliest Variety.

Curries Rust Proof, very early and prolific. The pods are long, full, stringless; of very fine quality.

Golden Wax. This valuable variety is about ten days earlier than the black wax pods, larze, long semi-round, brittle, stringless. Blossoming time sends up a tendril a foot longer than vein which drop off.

Hodson Wax, very large, tender, pods stringless, very productive. 


\section{DWIRE LILA AND UWIRE WHITE BEANS}

Burpee's Improved Bush Lima. Beans are large as Large Lima, stout growth, branches vigorously, bearing 50 to 200 large pods well filled with very large beans. 1 lb., $50 \mathrm{c} ; 2$ lbs., $90 \mathrm{c}$. Fordlook Bush Beaus, a very productive variety of the potato lima type. 1 lb., 50c; 2 lbs., $90 \mathrm{c}$. White Marrowfat, grown for sale in the dry state. 1 lb., 35c; 2 lbs., 50c; 10 lbs., $\$ 2.50$.

LIMA BEINS, Pole or Running Varieties

Clallenger Lima. Potato variety, five and six to a pod. 1 1b., 45c; 2 lbs., $75 \mathrm{c}$.

King of Garden Lima. Vigorous in growth and immensely productive, pods large, numerous and well filled and beans of an enormous size. Generally grown for main crop. 1 lb. 45c; 2 lbs., 75.

Iarge White Lima. Greatly esteemed variety. 1 1b., 45c; 2 lbs., $75 \mathrm{c}$,

\section{POLE SN IPIBEINS}

Kentucky Wonder, or Homestead Extra Early. Pods long, tender and good flavor, very productive. 1 1b., $45 \mathrm{c}$; 2 1bs., $75 \mathrm{c}$.

Scarlet Runner. Beautiful scarlet flowers; for ornamental and table use. 1 lb., 45c; 2 lbs., 80c.

Beaus, London Horticultural, Pole. This is a late zreen shell bean. The leaves are light colored, pods are about 5 inches long and are light green when young but take on a more yellowish appearance spotted with red as they grow older. 1 1b., 40c; 2 1bs., 75c.

Early Golden Cluster. Bright yellow pods, stringless, in clusters. 1 1b., 40c; 2 1bs., $75 \mathrm{c}$.

Dutch Case Knife. Pods are long, green flat. Shelled as well as snap. 1 1b., 40c; 2 lbs., $75 \mathrm{c}$.

\section{SHELL BEINS}

English Broad Windsor. Used as a shell bean when green. 1 lb., 50c; 2 lbs., $95 \mathrm{c}$.

Dwari Hortieultural. 1 lb., $45 \mathrm{c} ; 2$ lbs., $85 \mathrm{c}$.

White Marrow。 1 lb., 35c; 2 lbs., 65c.

\section{BEETS}

German, Runkelrub; French, Bourrache;

Spanish, Remolacha.

Price: 1 oz., 20c; 1/4 lbc, 50c; $1 \mathrm{lb.,} \$ 1.25$

Detroit Dark Red (Special). A splendid beet for market or home use, of a deep color, tender and of delicate. flavor

Dark Red Egyptian Croshy's (Special). The earliest beet in cultivation, color deep crimson; of excellent quality.

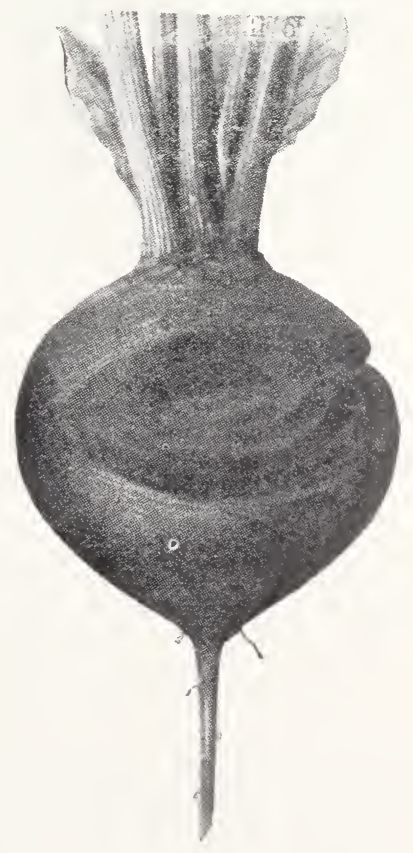




\section{BEETS-Continued}

Extra Early Eclipse. Very early, good size.

Early Blood Tumip. Standard early sort, an excellent variety.

Dewing's Blood Turnip. Of fine form and flavor.

Early Wonder. (See Specialties.) Globe shaped.

Long Smooth Blood Red. An excellent late variety.

swiss Chard. Used for its leaves, which are cooked as spinach. (See page 27.)

swiss Chard Lucullus. (See page 27.)

Any of the above varieties, 1 oz., 20c; $1 / 41 \mathrm{~b} ., 50 \mathrm{c} ; 1 \mathrm{Ib} ., \$ 1.25$.

\section{MANGEL-WURZEL AND SUGAR}

Varieties used for feeding stock. Sow 6 lbs. per acre.

Special Price in Quantities

Yammoth Red Mangel-Wurzel. Producing roots of mammoth size, very regular, and with a small top

Long Yellow Mangel-Wurzel. Good for general crop ......................................

Giant White 1/2 Sugar Beet. Extensively grown for feeding stock

and manufacture of sugar

$1 \mathrm{oz} . \quad 1 / 4 \mathrm{lb} . \quad 1 \mathrm{lb}$.

$.15 \quad .25 \quad .75$

$.15 \quad .20 \quad .65$

A rich, deep open soil is the best suited to the culture of Beets. Fresh manure is undesirable, but land that has been well manured the previous year is highly suitable. For an early supply sow in the spring as soon as the ground becomes fit to work, in drills about one foot apart and two inches deep. For main crop sow the first week in May, and for winter use sow in June. When the plants have obtained three or four leaves, thin out, so that they may stand eight or nine inches apart. Keep free from weeds by hand weeding and hoeing.

\section{BORAGE}

\section{0 cents Pkt.}

German, Borritch; French, Bourrache; Spanish, Berraja.

Borage, used as a pot herb; also as a salad, or can be boiled, and also for garnishing, but chiefly required foor claret cups and other cooling drinks. Bees are very partial to the flower .35

\section{BROCCOLI}

\section{0 cen ts Pkt.}

German, Spragel Kohl; French Chou Brocoli; Spanish, Broculi.

Italien Green Calabrese. A delicious vegetable having the combined flavor of asparagus and cauliflower. Although extensively used in Europe, it is only recently that it has been served in the better hotels in this country. Requires the same treatment as cabbage. Pkt., 25c; $1 / 4$ oz., $75 \mathrm{c} ; 1$ oz., $\$ 2.50$. 


\section{BRUSSELS SPROUTS}

10 cents Pkt.

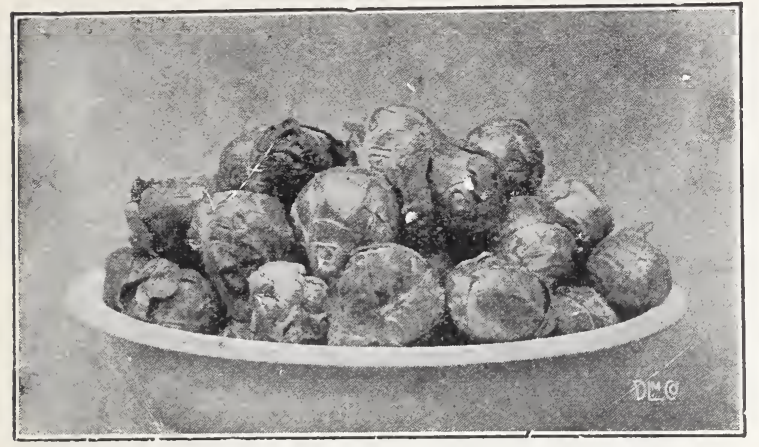

German, Sprossen-Kohl; French, Chou de Bruxelles; Spanish, Breza de Brussels.

Dalkeith Dwari Improved, a variety producing compact sprouts of excellent quality. Pkt., 10c; oz., 50c; 1/4 1b., $\$ 1.50$.

A tender, delivious vegetable. The plant froks two or three feet high, and produces from the sides of the stalks numerous little sprouts one or two inches in diameter, resembling cabbage. The leaves, which look like Savoy, should be broken down in the fall, to give the little cabbages room to grow. They are very tender and sweet after early frosts. Sow early in hot-beds, or in seed-beds in May transplant and cultivate the cabbage.

\section{CABBAGE}

10 cents Package, except yuoted otherwise.

German, Kopfkohl; French, Chou; Spanish, Berza de Pepollo.

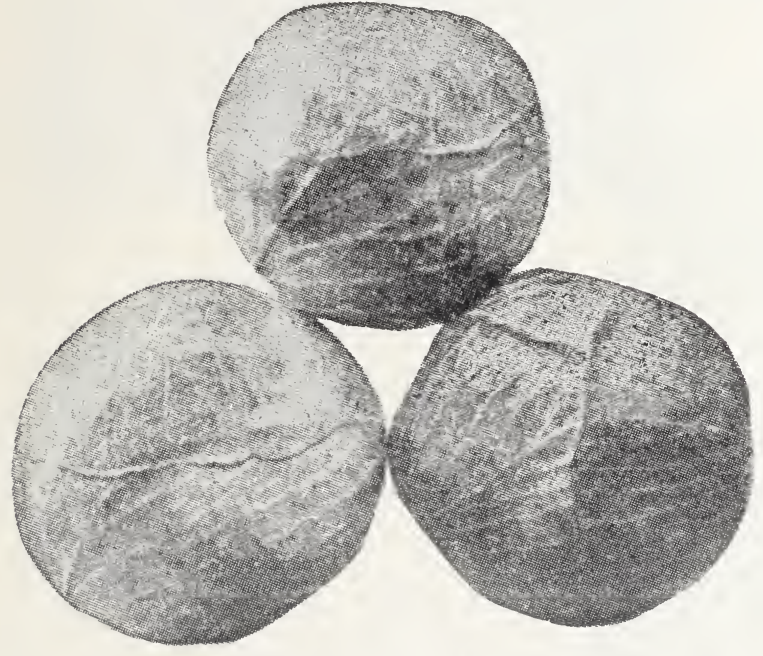

COPENHAGEN MARKET

III Head. The largest of the early cabbages. The head is roundish flat and remarkably solid; excellent for winter as well as early spring. All varieties of cabbage. 1 oz., 45c; $1 / 4$ lb., $\$ 1.50$, except listed.

Copenhagen Market. The finest, large, round-headed, early Cabbage; very solid and of fine quality; shortstemmed.

Eukhuizen Glory. Large, early, white, solid, ball shaped heads.

11 Seasons, fine variety, for second early or late growing, good size.

Early Jersey Wakefield. The leading variety for market, very early, of medium size, good quality, sure to head.

Charleston Wakefield. Large strain of the above.

Early Flat Dutch. This is one of the best early cabbages in cultivation.

Henderson's Succession. A second early or late variety, a sure header; seeds sown in Narch produce large head in June.

Danish Round Head Slort Stem. Large, round, solid, sweet and crisp, sure header.

Iarge Iate Flat Dutch. The most popular variety for late cultivation.

Mammoth Red Rock. Used almost exclusively for pickling.

I)rumliead Savoy (Americau). The largest heading sort, of excellent flavor.

Golden Icre. An early variety which closely resembles Copenhagen Market in type. As its name implies, it is a money-maker. It is 8 to 10 days earlier than Copenhagen Market but is smaller and can be planted closer. Beca"se of its earliness and fine quality it commands a higher price than any round-headed Cabbage. 1 oz., 75c; 1/4 1b., \$2.25.

('llinese (Pe Tsai). 1 oz., .75c; 1/4 1b., 2.25

L. I. or Hudson Red. 1 oz., .25; $1 / 4$ lb., .855 .

Earliest R. I. Red. 1 oz., .45; 1/4 1b., 1.50 .

For very early use plant in the a:tumn from 35 th to 25 th september, in a seed bed, and protect in cold frames during the winter, being careful to set them down to the first leaf. Transplant in the follow. col spring, as the soil will admit. For autumn and winter use, plant in seed-bed in Nay and early part of June, and when six inches high transplant into rich soil, two feet apart each way for the early varieties, and three by two and a half feet for the large winter varieties. To secure the best results, the soil should not be too dry, but should be thoroughly enriched, and the crop should be hoed at least once in ten days. Sow in hot bed early in spring, seed of the early kind for a second crop; also the late varieties for winter use. 


\section{CARROT \\ 5 Cents Package}

Except Quoted Otherwise.

German, Mochern; French, Carotte.

The Carrot, like other root crops, delights in a sandy loam, deeply tilled. It should never be sown on newly manured ground as forked roots are sure to be the result. It is best to sow on ground that has been well manured the previous year for some other crop such as Celery, Potatoes, Onions or Peas, but avoid such crop as Cabbaze and Turnips, or any of the tap rooted sections. For early or main crops sow the latter part of April; for later crops, they may be sown any time until the beginning of June. Sow in rows about 15 inches apart and half an inch deep, thinning out to three or four inches between the plants.

All varieties of Carrots. 1 oz. 20c: 1/4 lh. 65c.

Red-Cored Chantenay. A carrot with the shape and size and general characteristics of Chantenay. The core being the same color as the flesh, is inconspicuous, is tender and sweet, and does not look yellow in cooking.

Early Scarlet Horn. Old and favorite sort, much esteemed for early summer.

Half Long Danvers (Special). A variety intermediate in size and period of maturity between the preceding and the Long Orange.

Half Long Chantena! (Special). Like Nåntes, broader shoulder

Half Long Stump Nantes.

Half Long Stump Guarande or Oxheart.

Long Orange Improved. Roots of large size, equally adapted for garden or farm culture.

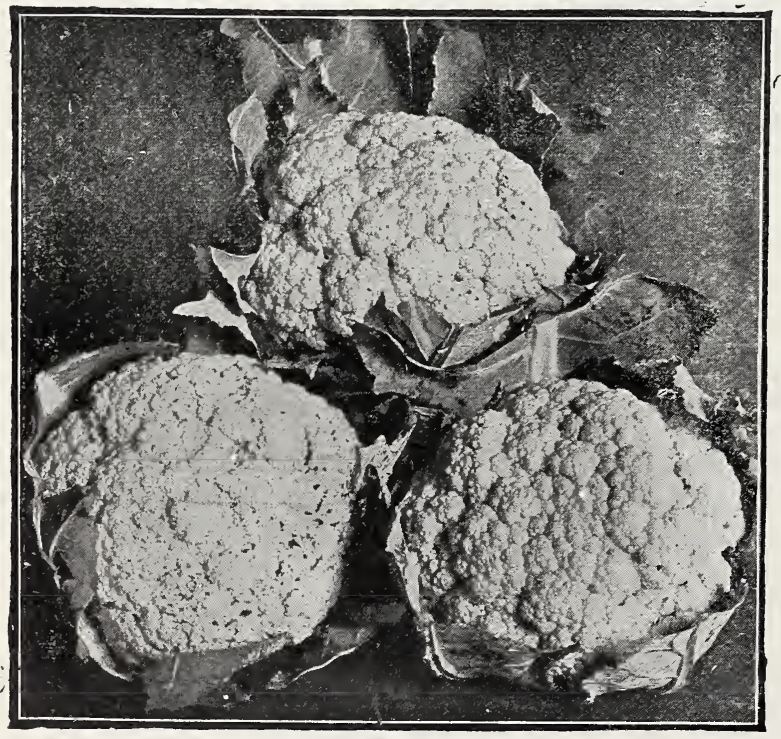

EARLY SNOW BALL CAULIFLOWER

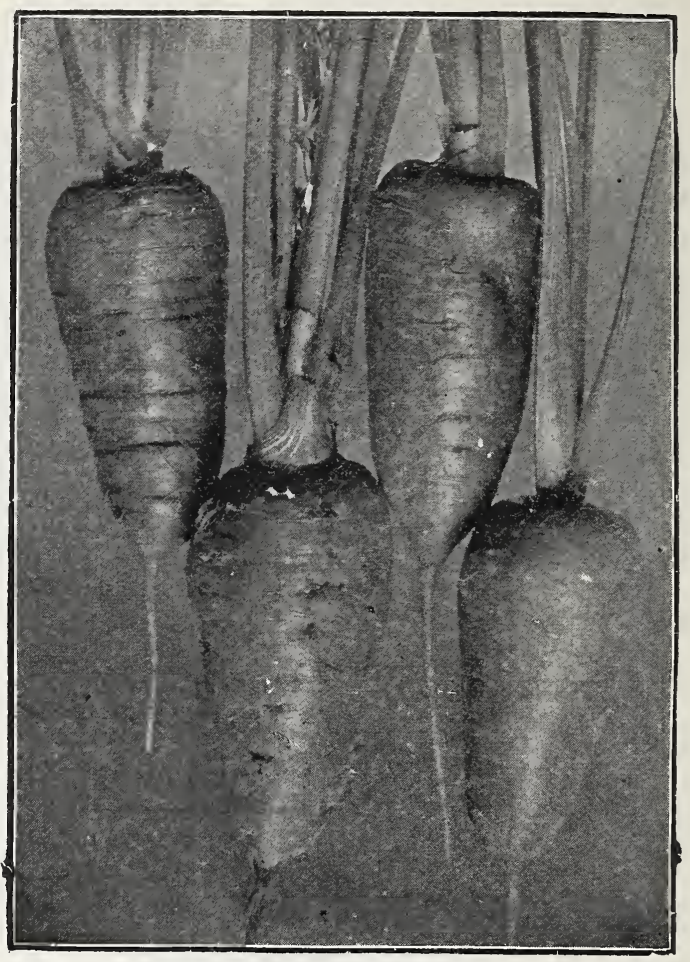

DANVERS CARROT

\section{CARDOON}

A vegetable that is grown somewhat like celery and served after the manner of asparagus. Sow in the open ground in May, and thin or transplant the seedlings so that they stand $2 \frac{1}{2}$ feet, one from the other, in rows 4 feet apart. A catch-crop such as beans, lettuce or beets may be taken between the rows. At the end ol the summer, and two or three weeks before using, it is necessary to blanch the Cardoons. The heads of the plants are tied together, straw is piled against them, and the surrounding soil is then heaped up against the straw. Pkt., 10c; 1 oz., 35c.

\section{CAULIFLOWER}

German, Blumen-Kohl: French, Choufleur; Spanish, Coliflor.

Large Early Snowball. Best for forcing under glass or open ground. Pkt., 25c; $1 / 4$ oz., $\$ 1.00 ; 1 / 2$ oz., $\$ 1.75 ; 1$ oz., $\$ 3.00$.

Early London. Pkt., $15 \mathrm{c} ; 1$ oz., $\$ 1.00 ; 1 / 4$ lb., $\$ 3.00$.

Denmark, Special Large Late. Very fine variety, large white, compact heads, the space necessary between plants is greater than other varieties. Pkt., $25 \mathrm{c}$ : 1/4 oz., $\$ 1.00 ; 1 / 2$ oz., $\$ 1.75 ; 1$ oz., $\$ 3.00$.

Danisli Giant or Drv Weather. $1 / 4 \mathrm{oz}$., $\$ 1.00 ; 1 / 2$ oz., $\$ 1.75 ; 1$ oz., $\$ 3.00$.

Early Snow Ball (Catskill). The finest strain of Snow Ball Cauliflower. Very early i/4 oz., $\$ 1.50 ; 1 / 2$ oz., $\$ 2.50$. 


\section{CIULIFLOWER-Continued}

Cauliflower delights in rich, moist soil and in dry seasons should be abundantly watered. The seeds may be sown in September and wintered over in the same manner as described for early cabbage. Where this is not practicable, it may be had nearly as well by sowing the seed in the hot-bed in January or February and transplanting the plants at two or three inches apart in boxes, or in the soil of another hot-bed, until such time as they are safe to be planted in the open ground, which in this latitude, is usually from the 15th of March to the 10th of April. It properly hardened off, they are seldom injured by being planted out too early.

\section{CELERY}

10 cents Package, except quoted otherwise.

German, Celeri; French, Celeri; Sparish, Apih.

Golden King. Grows about 24 to 26 inches high, long jointed- 8 to 9 inches to the joint. Long rib, good heart, faster grower, making a very desirable strain for an extra early crop. It blanches in 10 to 12 days. Pkt., $25 \mathrm{c} ; 1$ oz., $\$ 2.00 ; 1 / 4$ lb., $\$ 7.00$.

Golden Self-Blanching。 American Strain. Very choice. Standard early variety Pkt. 10 cents

Giant Pascal. Stalks very large, thick and crisp

$\begin{array}{lll}\mathrm{Oz} . & 1 / 4 \mathrm{lb} . & 1 \mathrm{lb} . \\ .65 & 2.25 & 600 \\ .40 & 1.10 & 350 \\ & & \\ .90 & 3.50 & 800 \\ .35 & 1.00 & 3.50\end{array}$
larger in growth.

White Plume Requires very little banking

Iwari White, soup Celery. An imported variety of fine flavor; soup greens

Golden Phenomenal. The plants are heavy. compact and full hearted, The stems are broad and thick, brittle and free from strings, of fine flavor and of excellent quality all through In other words, this is Golden Plume with all the good qualities of Golden Plume but in addition is taller with longer edible stems...

Lasy Blanching. A green celery, valuable for winter trenching. Blanches white, having fine nutty flavor. $1 \mathrm{oz}$, $40 \mathrm{c} ; 1 / 1$ lb., $\$ 1.10$.

Winter Queen. A late variety of medium height, with thick, solid stalks which blanch a creamy white color and keep well. 1 oz., $40 \mathrm{c} ; 1 / 4$ lb., $\$ 1.10$.

\section{CELERIAC KNOB-CELERY}

10 cents Plit.

German, Knob-Celeri;

French, Ceelri Rave.

Giant Prague. For soups, etc. When sliced and cooked makes good winter salad. $1 \mathrm{oz} ., 35 \mathrm{c} ; 1 / 4 \mathrm{lb} ., \$ 1.00$.

The seeds may be sown in the open ground in April, as soon as the ground can be nicely worked. Sow about half an inch deep, and he careful to press the soil over the seed. After the ground has been well prepared, plant in rows from three to four feet apart, according to the variety, settin: the plants about six inclees apart and pressing the soil firmly about the roots.

\section{CHERVIL}

\section{Package 10 cents}

German, Bisenlauch; French, Cerfeuil;

Spanish, Cerafolio.

Curled.....1 oz. 25c; $1 / 4$ lb., 75c; 1 lb., $\$ 2.50$

The young leaves are used in soups and salads. Sow thinly in May, in drills of an inch deep, one font apart.

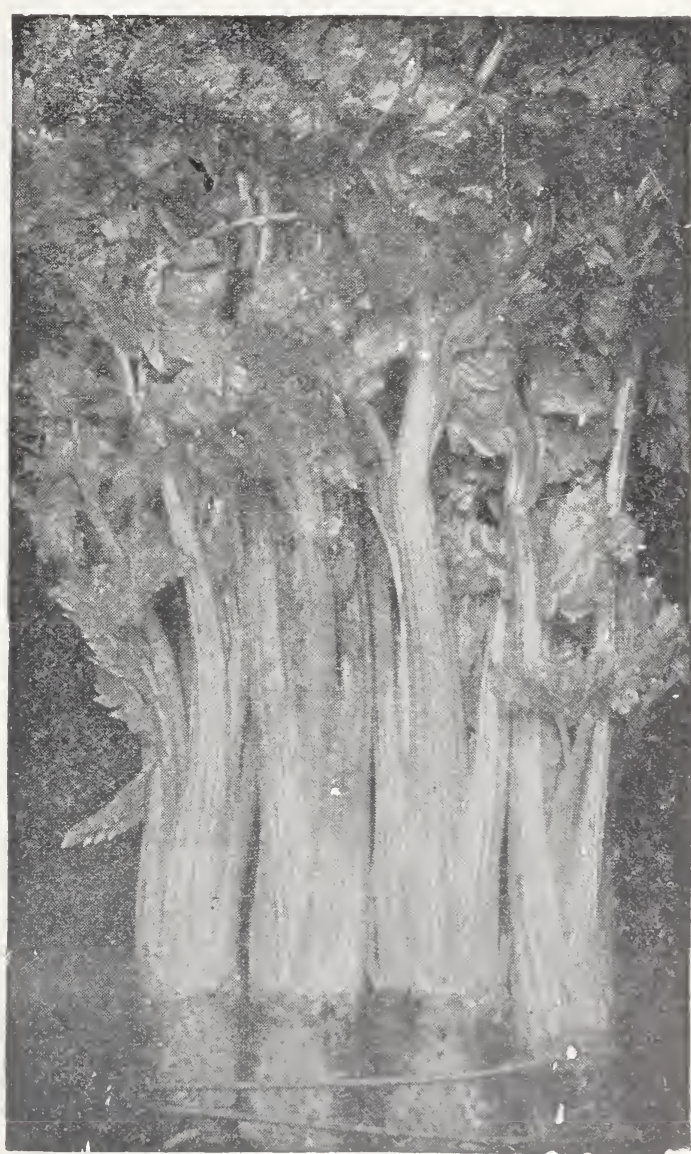




\section{P'kt, 10 C'ents CHICORY \\ Pkt. 10 C'ents}

German, Chicorie; French, Chicoree Saur; Spanish, Escarola.

Common. This variety produces the "Barbe de Capucin." a salad much used in France. Sown in June the roots are transplanted in autumn into sand in a cellar; the shoots of which will come up soon from the "Barbe de Capucin"

Large Rooted. Used to mix with or a substitute for coffee. The young leaves sprouted from year old roots are excellent as a salad

Witlofif or French Endive. Endive is one of the best salads for fall and winter use. Sow for an early supply about the middle of April. As it is used mostly in the fall months, the main sowings are made in June and July, from which plantations are formed at one foot apart each way in August and September. It requires no special soil or manure and after planting, is kept clear of weeds until the plant has attained its full size, when the process of blanching begins. This is affected by covering up the plants as they grow, with slats or boards, which serves the purpose of excluding the air and light............

Oz. $1 / 4 \mathrm{lb}$.

\section{CRESS}

German, Kress; French, Cresson; Spanish, Masturoz.

$\begin{array}{ccc}\text { Pkt. } & \text { Per oz. } & 1 / 4 \mathrm{lb} \\ .10 & .15 & .40 \\ 10 & 55 & 1.75\end{array}$

Curled Cress or Peppergrass

Water Cress

.55
.75

.25

.60

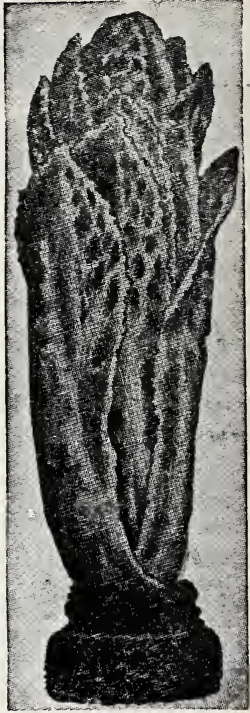

\section{WHITLOOF \\ CHICORY}

Are excellent for small saiads; the leaves, while young, have a warm, pungent taste. They can be used alone or mixed with Lettuce, Mustard, or other salad plants. Sow thickly at frequent intervals for succession, and treat in the same manner as mustard.

\section{Pkt. 5 cents $\quad$ CORN SALAD OR FETTICUS}

Pkt. 5 Cents

German, Ackersalat; French, Mache; Spanish, Macha Valeneanilla. Large Seeded . .1 oz., $25 \mathrm{c} ; 1 / 4$ lb., $75 \mathrm{c}$

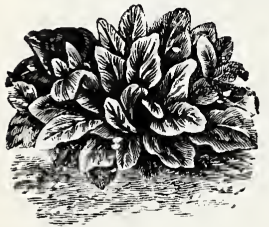

Corn Salad, Fetticus or Lambs Lettuce is used to a considerable extent as a salad. It is sown on the first opening of spring in rows one foot apart and is fit for use in six to eight week from the time of sowing. If wanted to come out early in spring, it is sown in September, cover up with straw or hay as soon as cold weather sets in and is wintered over the same way as Spinach.

\section{CORN-Sweet}

Pkt. 10 cents

German, Zuker, Welshkorn; French, Mais de sucre; Spanish, Maiz de Azucar.

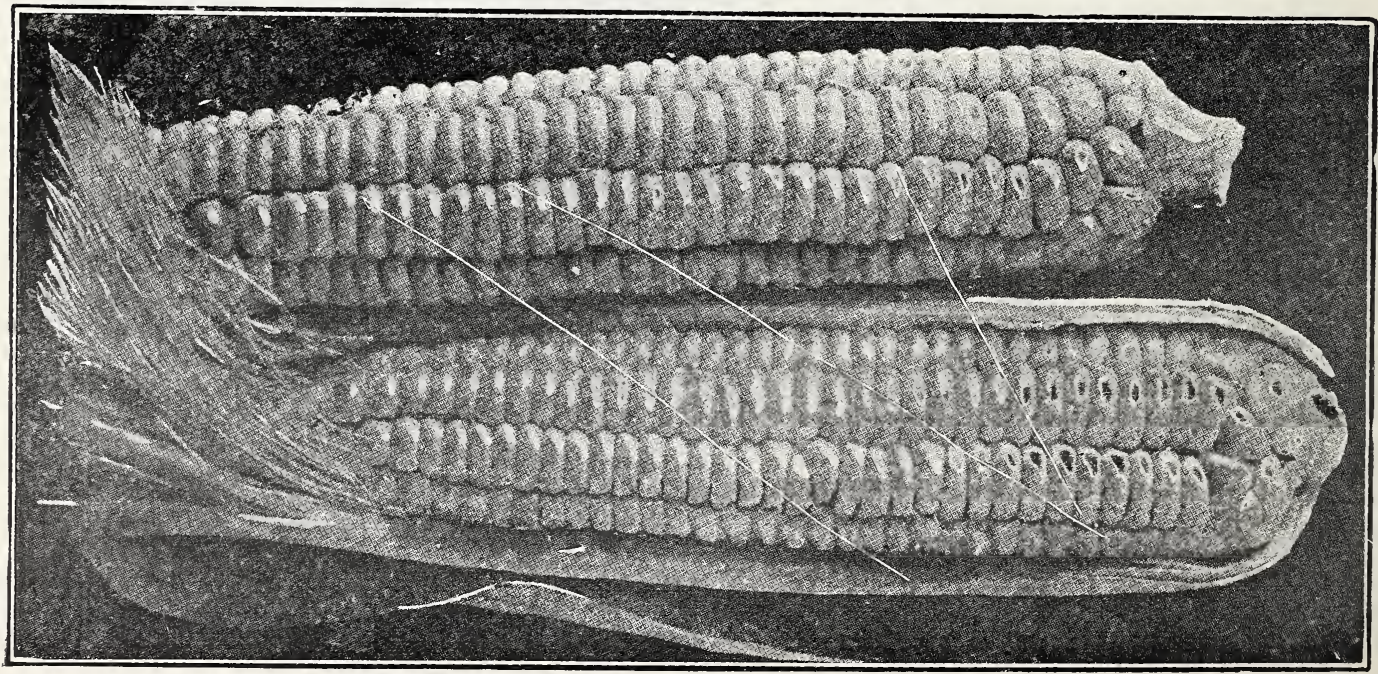




\section{CORN-Continned}

\section{EXTRI EARIY VARIETIES}

Golden Rod Early Yellow. Very sweet

Golden Bantam Extra Early. Yellow, very sweet and tender

Early White Cory. Earliest grown, fit for use 60 days after planting. Very sweet, good size, white cobs.

Surprise Early. White

Whipples Early Yellow-70 Days. A meritorious new yellow sweet Corn. Stalks 6 feet or more in height. Ears 12 to 16 rowed 7 to 8 inches in length. Matures a few days before Golden Bantam

Spanisl Gold Early. A new variety of sweet corn, ripens early, produces many good sized ears and among the first to give marketable ears which are well filled to the tips with 10 to 12 straight rows of bright yellow kernels

\section{SECOND EIRII OR INTERMEDITTE}

Golden Evergreen. Yellow

Early Champion. Large ears, very sweet and productive. The earliest large sort grown and fine for either home or market use

Long Island Beanty Early. Excellent, medium early, large size, sweet...........

\section{GENERII, CROP IND LATE}

Stowell's Evergreen. A large variety, of excellent quality, remaining longer in the green state than any other; general crop

Evergreen, Bantam-80 Days. A second early, one of the latest introductions to the Sugar Corn family. Some thirk it will take the place of the famous Stowell's Evergreen. Height of stalk $7 \frac{1}{2}$ to 8 feet, ears thick, 7 to 8 inches long

Mammoth Sugar. A late variety of large size, very sweet and immensely productive. A leading variety.

Conntry Gentleman. The sweetest and most tender of all sweet corn, late crop

Sweet Fodder. For ensilage

\section{FIELI) CORN}

astodon Dent. Very early, strong growing....

leaming Yellow. (Dent) early..

Early canada. Yellow kernels.

Large Yellow Flint

Large White Flint

\section{Dent Varieties}

Price on Application

Southern Horse Tooth. For fodder

Eureka White Dent, for ensilage, 12 to 14 rows, one of the best ensilage varieties, the fodder growing up to 17 feet, in some places matures in 120 to 130 days 


\title{
CUCUMBERS
}

\author{
10 cents Pkt.
}

\section{All varieties of Cucumbers, 1 ozo, 20c; $1 / 41 \mathrm{lb} ., 65 \mathrm{c}$.}

Early Fortune. Very early and productive. Uniform size. Good shipper.

Forhook Pickling, Prolific, medium size, skin thick.

Davis Perfect. For forcing or outdoors, long and straight, valuable for slicing.

Cool and Crisp. Very prolific; good for pickling and productive.

Japanese Climbing. Can be trained on trellis, or grown on the ground. Skin smooth, dark green; flesh pure white, crisp and mild flavor.

Nichols Medium Green. A valuable and handsome variety, in shape between White Spine and Long Green, an excellent sort for pickles and usful for forcing. Very prolific, fruit straight and smooth, color dark green; fresh, tender and crisp.

Arlington White Spine. Fine either for forcing \& $r$ for outdoors.

Early Green Cluster. A siort, prickly, slender variety, bearing in clusters near the root. It is a great bearer.

Long Green. A very excellent variety; a good bearer; about a foot in length, rather pointed at both ends; dark green, firm and crisp.

Green Prolific Pickling. Very prolific; and said by those who have tested it equally desirable as a market Cucumber.

West Indian Gherkin or Burr. A very small oval shaped prickly variety. It is grown exclusively for pickling, and should always be pickled when young and tender.

Clark's Special (Long Green). Very productive, disease resistant.

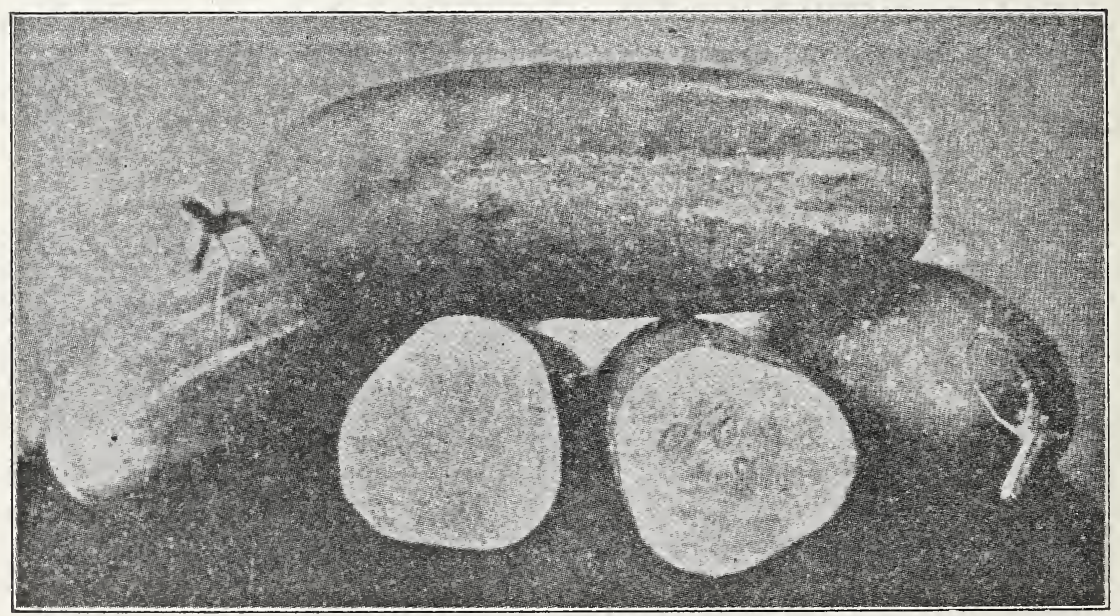

Cucumbers succeed best in warm, moist, rich loamy ground. They should not be planted in the open air until there is a prospect of settled warm weather. Plant in hills about four feet apart each way. The hills should be previously prepared by mixing thoroughly with the soil in each a shovelful of well rotted manure. When all danger from insects is past, thin out the plants, leaving three or four of the strongest to each hill. 


\section{DANDELION}

15 Cents Plt.

German, Pardelblume; French, Pisseulit; Spanish, Armagon.

Cultivated or French Common. A decided improvement on the wild dandelion. It is very early and vigorous. 1 oz., 35c; 2 oz., $60 \mathrm{c} ; 1 / 4$ lb., $\$ 1.00$.

Improved Thick Leared. Unsurpassed in thickness of leaf and deep green color. It is compact and forms an upright regular tuft at the center. This cabbaging sort is much superior to the common or uncultivated dandelion. 1 oz., $\$ 1.00$; 2 oz., $\$ 1.60 ; 1 / 4$ lb., $\$ 2.75$.

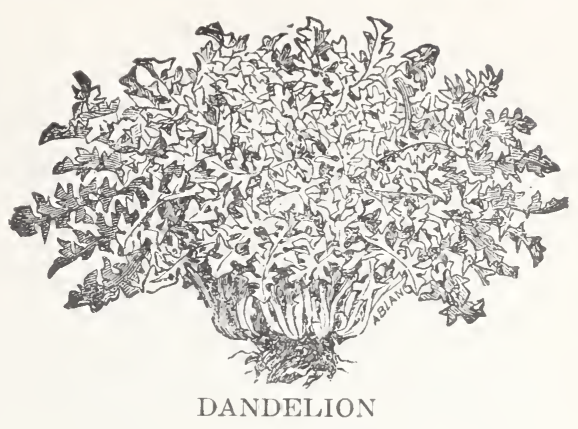

The Dandelion is much used for spring salads and resembles Endive. Sow the seed in May or June in drills half an inch deep and 12 inches apart. The plants will be ready for use the following spring.

\section{ENDIVE}

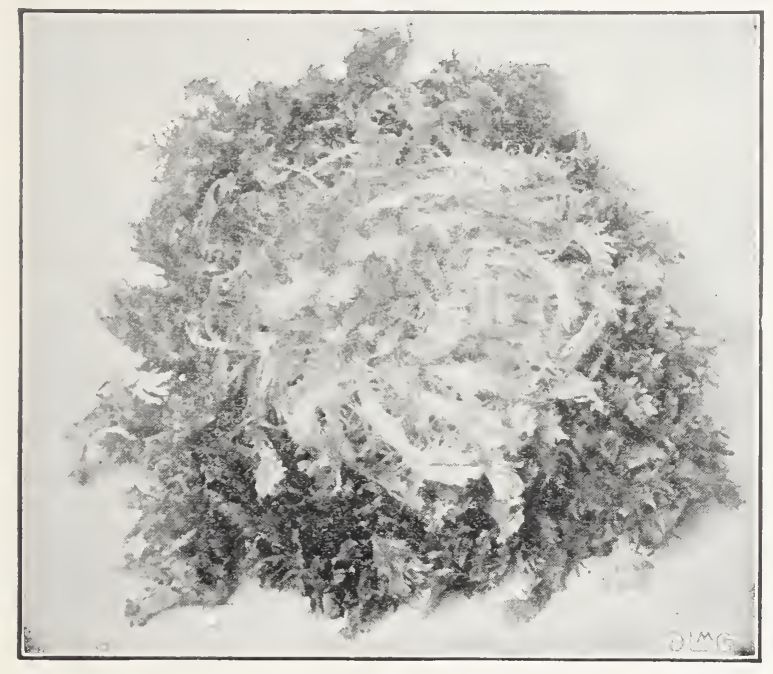

ENDIVE
All 5 c'ents P'kt.

German, Endevien; French, ('hicoree; Spanish, Endivia.

Green Curled Winter. German, Endevien; French, Chicoree; Spanish Endivia. Very hardy; leaves dark green, tender and crisp. $1 \mathrm{oz} ., 25 \mathrm{c}$; $1 / 4$ lb., $65 \mathrm{c}$.

Broad Leaved Batavia. (Escarolle) Chiefly used in soups and stews; requires to be tied up for blanching. 1 oz., $25 \mathrm{c}$; $1 / 4$ 1b., $65 \mathrm{c}$.

Early White Curled. (Self-blanching.) The best variety; grows to large size; very large and tender. $1 \mathrm{oz}$., $25 \mathrm{c} ; 1 / 4 \mathrm{lb} ., 65 \mathrm{c}$.

Full Golden Heart. (Escarolle.) For Fall Planting. $1 \mathrm{oz}, 25 \mathrm{c} ; 1 / 4$ 1b., $65 \mathrm{c}$.

\section{EGG PLANT}

\section{All 10 Cents Pkt.}

German, Eier Pflanzo; French, Aubergine; Spanish, Bereinfiena

New York Improved. Superior market variety of large size and fine variety.

Black Beauty Tendage. Earlier than New York. Improved and as large; purplish black.

\begin{abstract}
$1 \mathrm{oz} .1 / 4 \mathrm{lb}$.
\end{abstract} $.65 \quad 1.75$

.65

1.75

The Egg Plant is a tender vegetable, and must not be planted out until the weather is warm and settled. Sow early in spring in hot-beds, or if they are not convenient, sufficient plants may be raised for a small garden by sowing a few seeds in common flower pots or in boxes in the house. Plant out early in June from two to three feet apart.

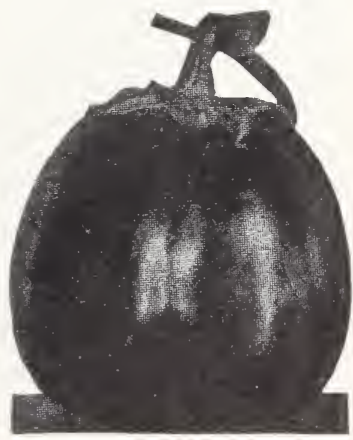

NEW YORK EGG PI,AN'I' 


\section{KALE}

P'it. 10 Cents, except where noted. German, Blatter-Kohl; French, Chou Vert; Spanish, Breton.

Silberian German Green or "Sproute." This variety is extensively used for early greens for which it is sown in the fall in rows one foot apart and treated in the same manner as Spinach; it is ready for use in early spring. Sowing can also be made in spring. $1 \mathrm{oz}$. $25 \mathrm{c} ; 1 / 4$ lb., $65 \mathrm{c}$.

I) wari Green C'urled scotch. Beautifully fringed dwarf growing kind with bright green leaves. $1 \mathrm{oz}$. $25 \mathrm{c} ; 1 / 4 \mathrm{lb} ., 65 \mathrm{c}$.

Tall Green Curled Scotch. Tall growing, very hardy variety, leaves a bright green, beautiful curled. 1 oz., $25 \mathrm{c} ; 1 / 4$ lb., $65 \mathrm{c}$.

Kale may be grown in almost any soil, but the richer it is the more abundant the product. Sow early in the spring, in prepared beds, covering the seeds thinly and evenly; trans$\mathrm{pl} n \mathrm{nt}$ in June and treat in the same

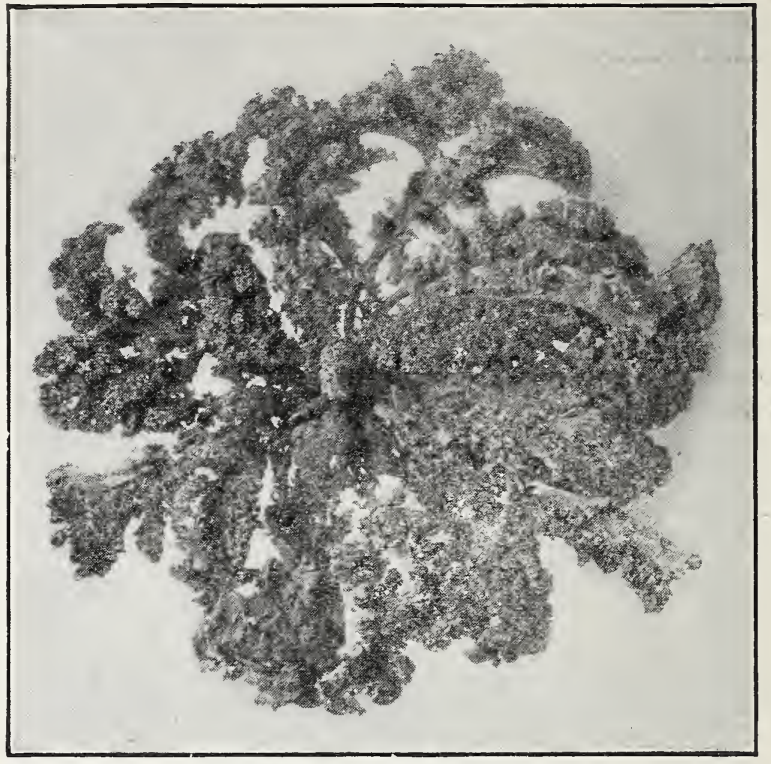

KALE manner as for cabbage. Of all the cabbage tribe this is the most tender and delicate and would be much more extensively grown than ' $t$ is, if its excellent qualities were generally known. The varieties are all extremely hardy. and are best when touched by frost.

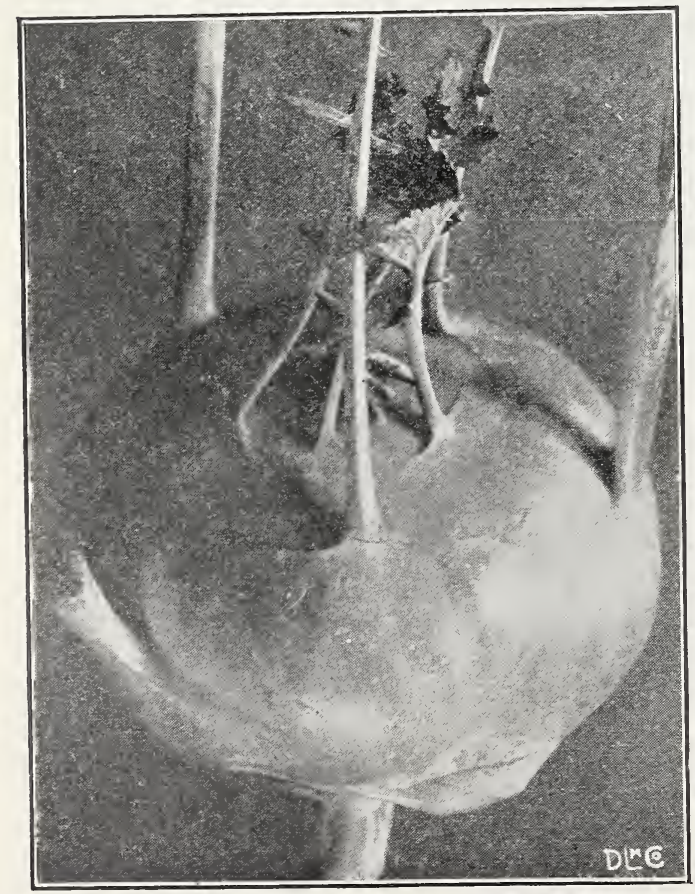

\section{KOHL-RABI}

Plit. 10 Cents

German, Kohl-Rabi; French, Chou Rave; Spanish, Colinabo.

Early White Vienna. Flesh white and tender; best market sort; good for table use. 1 oz., $25 \mathrm{c}$; 1/4 lb., $75 \mathrm{c}$.

Early Purple Vienna. Differing from the above in color, which is of a bluish purple. 1 oz., 25c; $1 / 4$ 1b., $75 \mathrm{c}$.

Kohl-Rabi or Turnip stemmed cabbage, is a vegetable that is not sa much cultivated as it deserves to be. The stem above the ground swells into a bulb, somewhat resembling a turnip; this again is covered with leaves. The edible part is the bulb which is dressed and served like turnip, is very delicate and tender when young. It is very hardy, withstands severe drought and is a good keeper. Cultivate the same as cabbage, but in hoeing be careful not to throw dirt into the heart of the plant, or the bulb cannot form. 


\section{LEEK}

Pkt. 5 Cents

German, Lauch; Frencn, Poireau;

Spanish, Puerro.

Large American Flag.

The kind mostly grown for market

Giant Musselburg, producing fan-shaped foliage; quite a strong grower, and a desirable market variety......

Large Rouen. Very large and fine

$1 \mathrm{oz} .1 / 4 \mathrm{Ib}$.

The Leek is very hardy and easily cultivated; it succeeds best in a light, but well enriched soil. Sow as early in the spring as practical, in drills one inch deep and one foot apart. When six or eight inches high they may be transplanted in rows ten inches apart each way, as deep as possible; that the neck, being covered, may be blanched. If fine leeks are desired, the ground can hardly be made too rich

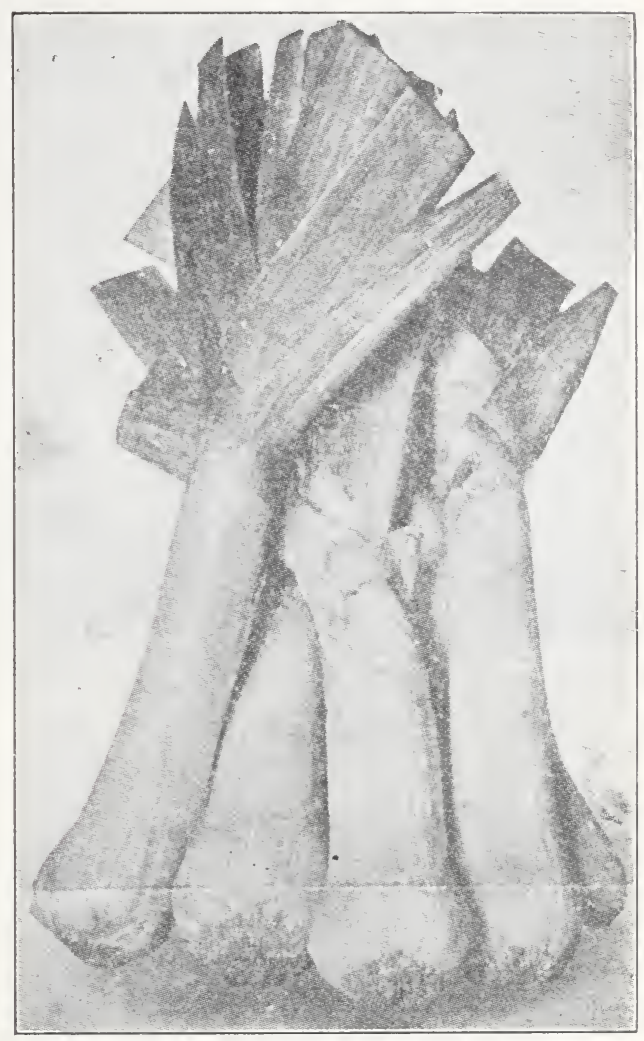

LEEK

\section{LETTUCE}

\section{l'kt. 10 Cents}

German, Laitick; French. Laitue; Spanish, Lechuga.

Paris White Cos, Trianon or Romaine-55 Days. White Seed. This variety, maturing for table in eight weeks from germination, should be found in every vegetable garden as it is a thoroughly reliable Lettuce. A strong grower and very productive with long, shell-shaped leaves of most excellent quality. It is a self-folder, but when the plant is over half grown, it is best tied up with a soft string or a wisp of grass that the inner leaves may be blanched perfectly white, in which condition they are more crisp and decidedly more palatable than varieties of a Cabbage-heading habit. It is a mystery why it does not displace them, especially as a given amount of ground will produce more than twice the amount of edible leaves that can possibly be obtained from any round-head. 1 oz., 25c; $1 / 4$ lb., $75 \mathrm{c}$. 


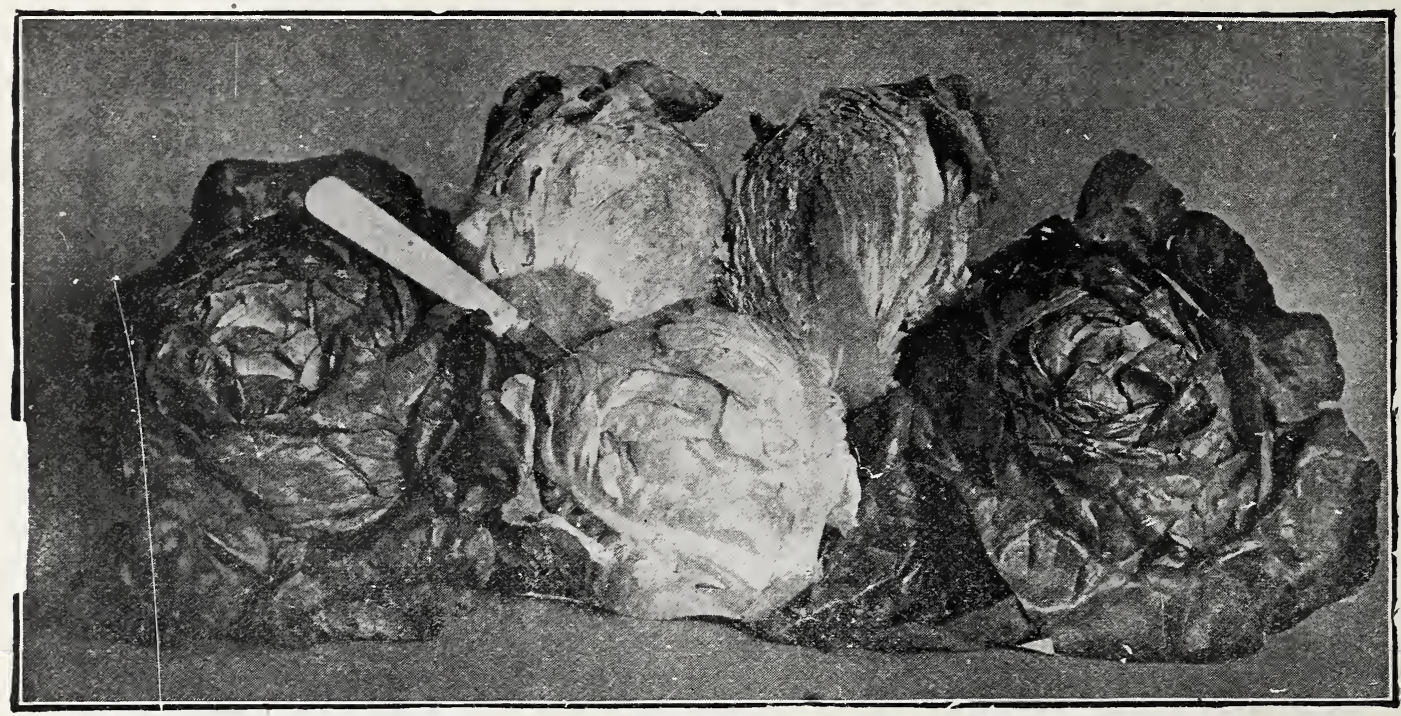

\section{MAY KING LETTUCE}

German, Laitick; French, Laitue; Spanish, Lechuga.

Special Big Boston W. S. Extra Select. Heads creamy white whether grown $1 \mathrm{oz} . \quad 1 / 4 \mathrm{lb}$. in open garden or under glass. Very large, slightly tinged with reddish brown, solid and uniform. White seed. Seed saved from a selection better than that producing the ordinary stcck of Seed. It has a high reputation in the market-gardening sections. The most generally used variety. We advise all to plant this excellent strain of Big Boston

New York or Wonderful. Round Solid Head. Heat resisting. Grows larger than Iceberg and matures 10 days earlier.

May King Lettuce. Very early, sure header, solid, good flavor

Big Boston. Similar to Boston Market, double this size. Selected

Early Curled Simpson. Very early and an excellent sort for forcing; is largely grown by the market gardeners

Salamander Head. Fine compact head, resists heat

Black-Seeded Butter. Fine market strain

Large White Cabbage. Excellent for summer; heads of good size

Black-Seeded Simpson. Stands the summer well

Shotwell's Brown Head. Large and handsome; heads hardy; standing summer heat without injury

Boston Market. Large solid heads, very fine for forcing, and of fine flavor...

Iceberg Favorite Summer Lettuce. Heat resisting. Very crisp, strong center ribs which bend toward center of plant, keeping it thoroughly blanched...

Unrivaled, An improvement on the White-seeded Big Boston, forming very solid, large, pale green heads without the reddish brown tinge, and of excellent quality. Forms a head in six weeks; at least ten days earlier than the regular Big Boston. May be sown all through the year and stands heat remarkably well. Is crisp, tender, and solid

Lettuce is the most popular of all salads. It is easy of cultivation, but likes a good rich soil. For early use, sow Simpson and May King under glass in February and March and transplant as soon as the ground can be worked. Later sowings may be made in the open ground for successions as long as the weather permits; thin out well or the plants will be weak, and set in rows two feet apart and eight inches between the plants. The best early plants are obtained by sowing in the open ground in September and transplanting to cold frames the latter part of October, being wintered over in the same manner as early Cabbage. Lettuce requires good ground and abundant moisture. 


\section{MELON, MUSK}

\section{Package 10 Cents}

German, Melone; French, Melon; Spanish, Melon Muscatel.

Hearts of Gold. A selection from Hoo Doo, this melon runs very uniform in size. It is a splended variety and is increasing in use...

Tip Top. This kind cannot be excelled for its eating qualities. The flesh is a bright salmon color, remarkably thick, sweet and spicy. It varies from round to slight oblong and with a green skin turning to a lemon color as it approaches maturity.

Honey Dew. Large, round, delicious rich green flesh ..........................................................

Paul Rose. Handsome, oval, orange flesh, sweet

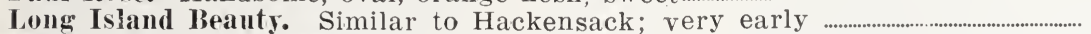

Miller's Cream or Osage. Flesh and salmon color and very thick..........................

Hackensack. Variety of Green Citron, well known among the New York
market gardeners, grows to a very large size, productive, exquisite flavor

$1 \mathrm{oz} . \quad 1 / 4 \mathrm{lb}$.

.25 75

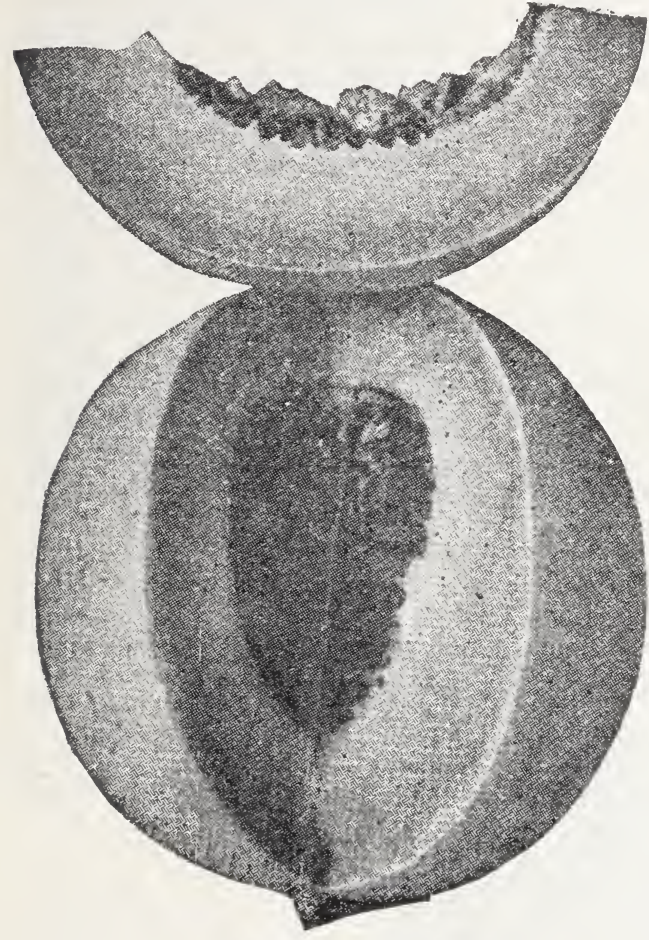

HONEY DEW MELON
Long Vellow Cantaloupe. Yellow flesh. suitable for the market ............................

Rocky Ford. Very sweet; spicy flavored, small and oblong. most popular sort

Montreal Marliet. A very large green "Nutmeg" type, almost round, heavily netted; thick, luscious flesh; late and especially adapted to cooler climates
Melons thrive best in a moderately enriched live soil; the hills should be six feet apart each way. Previous to planting incorporate well with the soil in each hill a couple of shovelfuls of thoroughly rotted manure; plant twelve or fifteen seeds in each hill in May, and when well up, thin out three or four of the most promising. Pinch off the leading shoots as the growth becomes too luxuriant, and if the fruit sets too numerous thin out when young, which will increase the size of those remaining, and cause them to ripen quicker.

\section{WELON, WITER}

Package 10 Cents

German, Wassermelone; French, Melon d'Eau; Spanish, Zaudia.

Tom Watson. Long and 8 to 10 -in. diameter. Thin rind, crisp flesh, fine flavor

Pride of Georgia. Dark green, oval in shape; crisp and sweet; very large rind thin; flesh scarlet; solid, very sweet and delicious

$1 \mathrm{oz} . \quad 1 / 4 \mathrm{lb}$.

Phinney's Early. Flesh deep red, of a very superior quality; a valuable early market variety

Ice ('ream. (White seeded), fruit of medium size, nearly round; skin pale green; rind thin; flesh scarlet, solid crisp, excellent

Kleckley's Sweets. Vines vigorous and productive' fruits are medium to large, oblong, tapering slightly toward the stem end; dark green. The flesh is very bright, rich red and exceeding]y sweet, crisp, and tender. Combines earliness, size and quality

Cole's Early. Early variety suitable for home market, but on account of its thin rind is not a good shipping melon. Medium size, skin dark green with light stripes; flesh, rich, dark red; luscious and sweet....... 


\section{MELON, WATER-Continued}

Mammoth Iron Clad. Long and large; thin skin, deep red flesh

$\begin{array}{cr}1 \mathrm{oz} . & 1 / 4 \mathrm{lb} . \\ 20 & 60\end{array}$

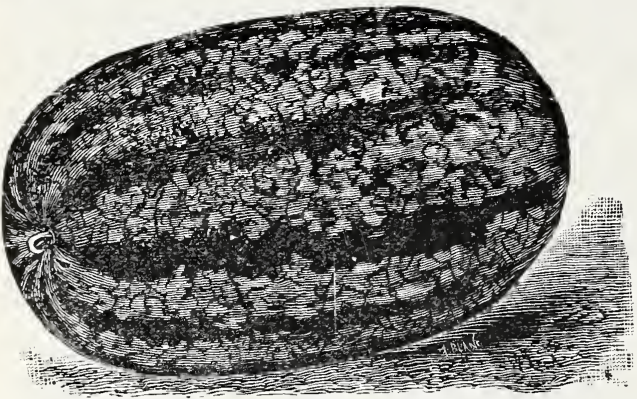

Citron. (Red seeded), round

IRON CLAD

handsome fruit of small size and used in the making of sweetmeats and preserves

Plant in hills directed for Muskmelons, giving them more room, as their vines extend much farther. If they are wanted of a large size, three or four melons to each plant will be sufficient, and when only one is allowed to grow from each plant they will grow to an immense size.

\section{MUSHROOMS}

German, Chimpignoubrut; French, Champignon; Spanish, Hongo.

American Spawn Bricks

Per brick, 3ృ̄c; 10 bricks, $\$ 2.50 ; 25$ bricks, $\$ 5.50$

Mushrooms should be grown either in a building especially erected for the purpose or some shed, stable or cellar, where the temperature of from 40 to 60 degrees can be kept up in winter. To every barrow load of fresh horse droppings add about the same weight of loam or soil of any kind that has not been manured. Turn the heap every day, so that it is not allowed to heat violently, until you have quantity enough to form a bed of dimensions required. Be careful that your heap is under cover, so that it cannot possibly get wet. The most convenient size is from three to four feet long and eight inches deep.

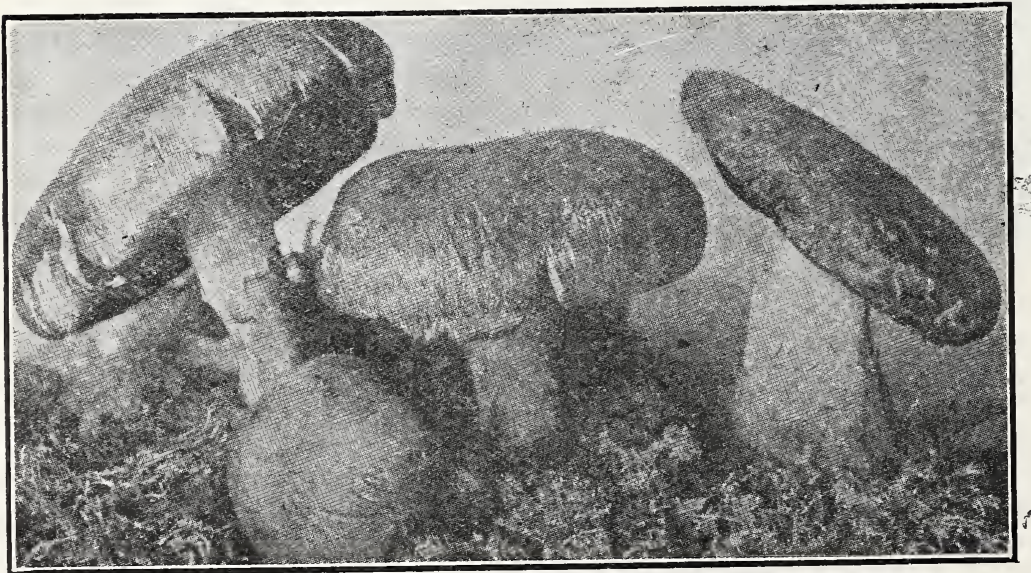

\section{MUSHROOMS}

Prepare the mixture of loam and manure, making the bed in layers and pounding down each with the back of a spade. Leave this to heat through for a few days, and as soon as the heat sub. sides to 90 degrees make holes in the bed about a foot apart each way into whicn put pieces of spawn two or three inches in diameter; fill up the holes with the compact and at the expiration of $s$ week or ten days spawn will have thoroughly diffused

itself through the bed. Now spread a layer of fresh soil over the 'heap to the depth of two inches, firm it down moderately and cover with three or four inches of hay or straw. Examine the bed often to see that it does not get dry. When water is given it should be at a temperature of about 100 degrees. One brick to each 10 square feet. 


\section{ONION}

\section{Package10 Cents}

German, Zweibel; French, Oignon; Spanish, Cebolia.

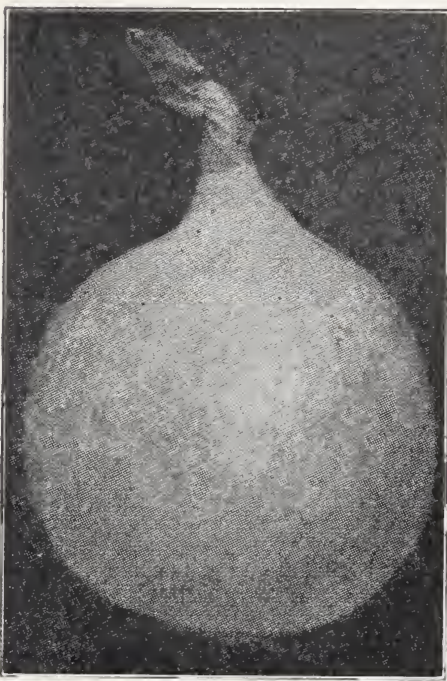

Yellow Globe Prize Taker, 90 days.
Varly Red Flat. About ten days earlier than the Large Red, and not quite so large Iarge Red Wethersfield. The staple variety of the Eastern onion growers; of large size, deep in color, a good keeper.

Southport Red Globe. Similar to the large Red in flavor and color, but quite distinct in form, being nearly globular...........

Yellow Giobe Danvers. An excellent variety, mild and very productive; ripens early and a good keeper

White Portugal or Silver skin. A handsome onion of mild flavor; extensively grown for pickling

southport White Globe. Form nearly ovoid symmetrical, keeps well, is an excellent variety

southport Yellow Glohe. As above except color

White Welsh (Hardy). A very hardy sort which is used as a bunch onion. Seed should be sown in spring or early summer. They will then make fine thick stalks for the following spring. Seed can be sown in August, but it is not as satistory. It produces a large white stalk, but does not make a bulb

Prizetaker. Grows uniform in shape; is of immense size, measuring from 12 to 16 inches in circumference, while under special cultivation specimen bulbs have been raised to weigh from 2 to 3 pounds each; its pure white flesh is fine-grained, mild and delicate in flavor.

Barletta Onion is a white small type, semi-flat and is grown largely for pickling purposes. As it is medium early, it could be also used for an early garden Onion

The onion thrives in a rather strong deep, rich loamy soil, and unlike most vegetables succeeds well when cultivated on the same ground for successive years. The ground should be deeply trenched and manured the previous atumn, and laid up in ridges during the winter to soften. As early in the spring as the ground is in working order, commerce operations by leveling the ground with a rake, and tread firmly; sow thinly in drills about a quarter of an inch deep and one foot apart; cover with fine soil and press down with the back of a spade or a light roller. When the young plants are strong enough, thin gradually so that they stand three or four inches apart.

\section{ONION SETS}

White Onion Sets Yellow Onion Sets Red Onion tiets
Price

on

Application
Potato Onious

Shallots

Red Top Onions
Price

on

Application 


\section{OKRA OR GUMBO}

Package 10 Cents

German, Essbarer Safran; French, Gomo; Spanish, Quibombo.

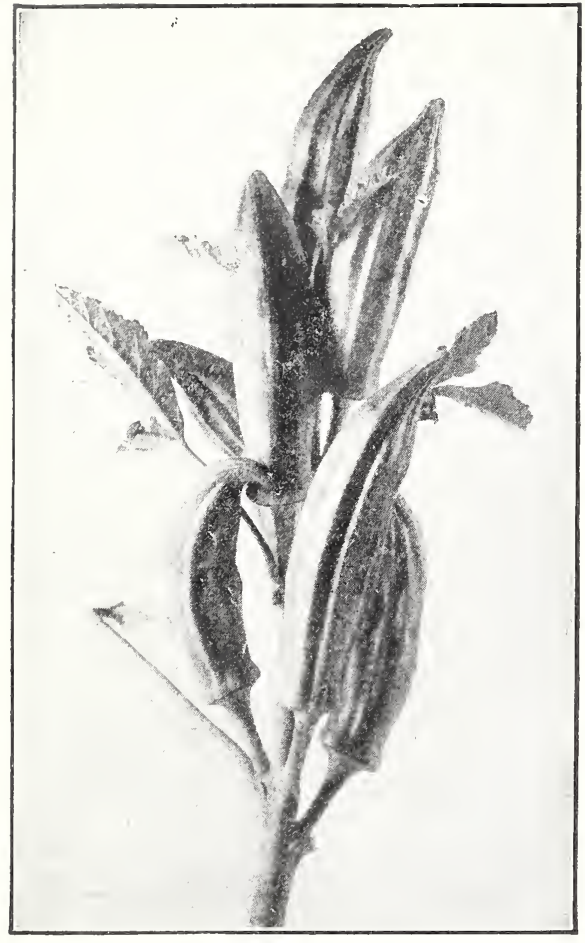

I.ONG GREEN OKTA

German, Petersilie; French, Persil; Spanish, Perjil.

Exter Double Curled, A fine dwarf variety excellent for garnishing

Phain lowes, Hardier than the curled variety..

Aong Green. Fine long pods, very good

$1 \mathrm{oz} . \quad 1 / 4 \mathrm{lb}$.

The pods in a young state are used in soups, sauces and stews, and are very wholeome and nutritious. It is the easiest culture and grows freely, bearing abundantly when grown in ordinary garden soil. It is sown at the usual time of all tender vegetables in drills two inches deep, setting the plants from two to three feet apart.

\section{PARSNIPS}

\section{Package 10 cents}

German, Pastinake; French, Panais;

Spanish, Chirivia.

\section{Loug Simooth or Hollow Crown.}

Long roots

$1 \mathrm{oz} . \quad 1 / 4 \mathrm{lb}$.

They succeed best in a deep rich soil that has been well manured the previous season, as manure freshly applied tends to the production of forked and illshaped roots. Sow the seed early in spring in drills eighteen inches apart in the garden, and three feet apart in the field, thin the plants to six inches in the drill.

\section{PARSLEY}

\section{Package 5 Cents}

1 oz. $1 / 4 \mathrm{lb}$.

$.15 \quad .45$

$.15 \quad .45$

Hambura, or Rontesl, Edible roots

Should be sown very early in the spring in beds or in lines, and the seeds which are somewhat slow to vegetate should be previously soaked 24 hour in warm water. The soil should be kept free from weeds, which should be extracted by the hand, so as to avoid disturbance of the seed when about to germinate. As soon as the plants are large enough they should be thinned out so as to stand five or six inches apart.

\section{PEAS}

Package 10 Cents

German, Erbsen; French Pois; Spanish, Guisantes. Extra Early Varieties

$1 \mathrm{lb} . \quad 2 \mathrm{lb}$.

Horld Hecord. Among early main-crop Peas of medium height, Gradus, or Prosperity, takes first place; happily named, indeed, on account of its high yield and superb flavor. In World's Record these points are more than maintained; the yield is as high and the quality, if anything, is enhanced. The great point in favor of the new sort is its earliness, the period from seed to maturity being less by a week than the standard Gradus

45




\section{PEAS-Continued}

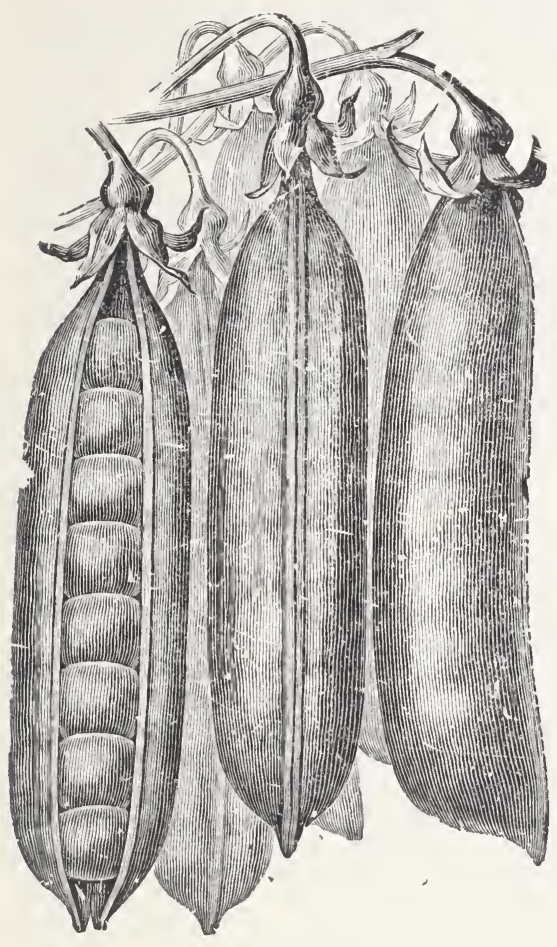

$1 \mathrm{lb}$.

$21 \mathrm{~b}$.

Nott's Excessior. Extra dwarf wrinkled pods larger than American Wonder, 1 foot...............

Ilaska. Earliest of all

First and Best. One of the best extra early Peas. An improved strain of the Extra Early Market, height $2 \frac{1}{2}$ feet...

little liem, A dwarf green wrinkled Market, very prolific of superior flavor, and a first early, $1 \frac{1}{2}$ feet

Everbearing. Good sized pea, long pods, height $2 \frac{1}{2}$ feet................... .40

Pride of the Market. Very large pods, green peas, sow thin, height 2 feet

i)wari Telephone. Same quality and productiveness as Telephone excepting the vines grow 2 feet high, pods are large and filled with immense peas of excellent flavor and sweet

\section{('ENERAI, C'ROI'}

Champion of Engiand. A popular wrinkled variety of delicious flavor, profuse bearer. Peas are very large, tender, height 5 fet

Telephone. This is the best pea for general crop, both for home and market use. Immediately productive and of finest quality. Vines very strong, averaging 18 to 20 large pods per stalk, 4 feet

When grown as a market crop, peas are not staked, but sown in single rows, two or three inches deep, two or three feet apart, according to the variety. When grown in small quantities for private use they are sown in double rows 6 or 8 inches apart and the rows 3 feet apart, the tall varieties staked up by brush. For an early crop, sow as soon as the ground can be worked, and make repeated sowings every two weeks for succession. A quart is sufficient for a row of about eighty feet. 


\section{PEPPER}

\section{Package 10 Cents}

German, Pfeffer; French, Piment; Spanish, Pimento.

California Wonder. S. An exceed-

ingly large and showy variety. It somewhat resembles the Chinese Giant in size and shape, but the walls are much thicker, making the pepper heavier and firmer than any other sort. The flesh is sweet, and quite mild. Pkt., 10c; 1 oz., $75 \mathrm{c} ; 1 / 4$ 1b., $\$ 2.00 ; 1$ 1b., $\$ 7.50$.

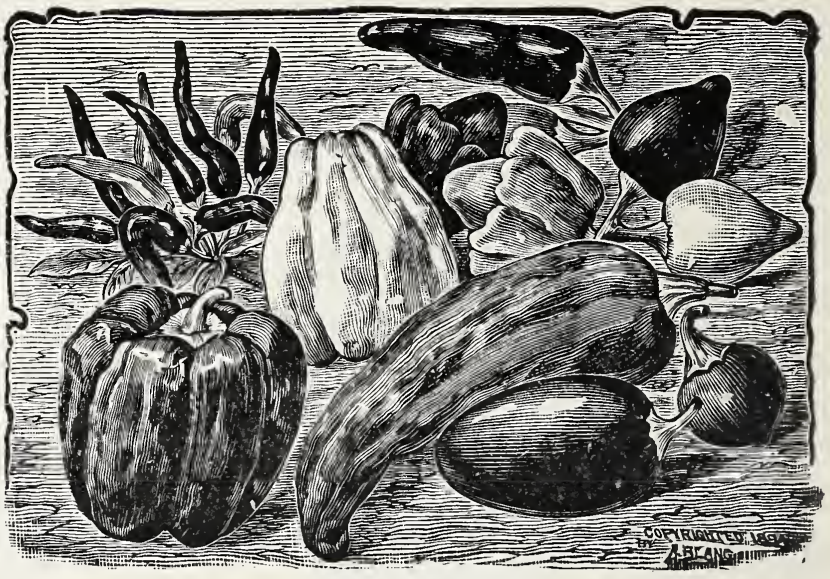

\section{H-Hot-S-Swees}

PEPPERS

Crimson Giant or Ohio Crimson-S-130 Days. Similar to the Ruby King, but broader, longer and deeper fruited like Chinese Giant, a monster about $4 \frac{1}{2}$ inches long by 4 inches wide, but not so large as Chinese Giant. Vines strong, dark, large leaved, very productive in fruit, frequently bear 7 to 8 fruit at once and covered by a succession of smaller fruit. Sold by many as Chinese Giant

Ruby King. S. Very large; bright red.

Large Bell or Bull Nose. S. An early variety of mild flavor ...........................................

Sweet Mountain or Mammoth. S. Of large size, best for mangoes

$1 \mathrm{oz} . \quad 1 / 4 \mathrm{lb}$

Chinese Giant. S. Double the size of Ruby King. This is the largest and finest mild Red Pepper. Flesh is thick and unusually mild. Productive bearer

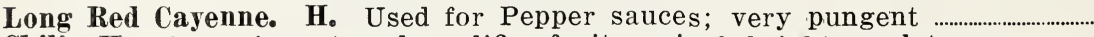

Chili. H. Very piquant and prolific, fruit conical, bright scarlet

Hot Mango Pepper. H. Very Hot, best for Pepper Sauce and Pickling ............

The Pepper or Capsicum is valuable for its seasoning qualities, as well as for pickling. Sow early in heat and transplant when the weather is warm and settled, or sow in warm situation in the garden about the middle of May. Plants should be set a foot and a half apart.

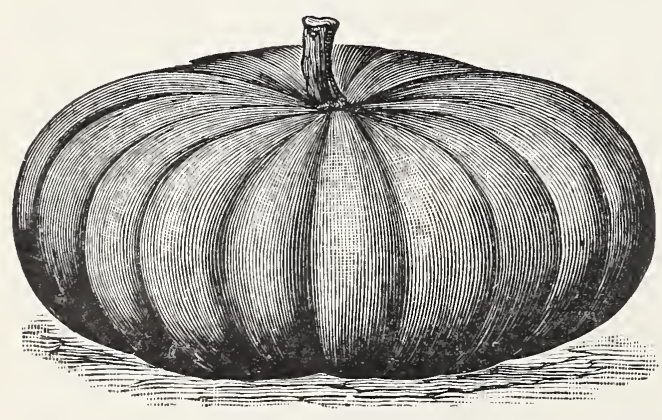

CHEESE PUMPKIN

\section{PUMPKIN}

\section{Package 10 Cents}

German, Kuerbis; French, Courge;

Spanish, Calabaz a Tetanera.

Calhoun. Flesh wonderfully $1 \mathrm{oz} .1 / 41 \mathrm{~b}$. thick, fine grained ....................... $\quad .20 \quad .65$

Cheese Pumpkin. This is an unusually fine strain grown exclusively for the most critical trade. A very large, flat ribbed fruit, of a beautiful, buff yellow color; the interior is of fine quality.

Connecticut Field. Very productive, largely grown for feeding stock 


\title{
RADISH
}

\author{
5 Cents Package
}

German, Retting; French Radis; Spanish, Robanitos.

Special price to Market Gardeners in quantity lots.

Get our Market Gardeners Price I,ist

Early Scarlet Globe. The standard market radish. Our strain is unsurpassed for earliness; rich color ana uniform shape.

1 oz. $1 / 4 \mathrm{lb}$

arly Scarlet Turnip. The standard variety, of quick growth, mild and crisp when young

Early Scarlet Turnip. (Forcing) variety, maturing in three weeks

Early Scarlet Turnip. White tipped. A beautiful new early kind, round in shape; color scarlet, tipped with white, a favorite for market gardeners

French Breakfast. Of quick growth, very mild and tender, of oval form; color scarlet tipped with white

ong Scarlet. One of the leading kinds

Rose China Yinter. Flesh firm and piquant; excellent for winter un...................

White Summer Turnip. A summer variety of mild flavor

Half Long Black Spanish

Black Spanisl.. Round

Icicle. Long, pure white, suitable for forcing...

There are two classes of Radishes, those for Spring and Summer use, which are small and arrive quickly at maturity and with proper care can be kept all winter. The Summer radishes should be used while young and tender; if allowed to grow too long they become tough and stringy; they thrive best in high, rich soil. For a successful supply, sow from the middle of March until September, at interval of two or three weeks. For an early supply they may be sown on a mild hotbed in February. The winter varieties may be sown from the latter part of July to the middle of September.

\section{RAPE}

Italia Broceoli Rape

\section{SORREL}

\section{0) ('ents P'uckage}

Large Leaved French. The best garden variety, having large pale green leaves of fine quality, resembling spinach, only not so broad. Perfectly hardy, can be cut five or six times..

Fine Leaved Sorrel. Has an upstanding plant with long slender leaves of medium green; it is more attractive and daintier in appearance than the more commonly known Thick Leaved Sorrel. This can also be planted in the fall for use the following summer

\section{SPINACH}

\section{Cents Package}

German, Spinat; French, Epinard; Spanish, Espinaca.

Special price on lots of 5,10 and $25 \mathrm{lbs}$.

Gaudeflay, Broadleared (New). A new Smoothleaf Spinach which we consider superior to any smoothleaf variety of that type. It grows very quickly and yet stands 7 to 10 days longer than Viroflay and other smoothleaf types. The leaves are very thick and of a tremendous size... 
Iong Standing, Round Leaved. $1 \mathrm{oz}, 10 \mathrm{c} ; 1 / 4 \mathrm{lb}, 25 \mathrm{c}$.

Iarge Viroflay. A new variety, with leaves much larger and thicker tian the old variety. $1 \mathrm{oz}, 10 \mathrm{c} ; 1 / 4 \mathrm{lb} ., 25 \mathrm{c}$.

Bloomsdale Savoy Leaved. A large, curled, thick leaved variety, the market gardener's favorite. 1 oz., 10c; 1/4 lb., $25 \mathrm{c}$.

Saroy Leaved New Long Standing. In offering this new variety, we do it with confidence that it will prove a favorite among growers who grow the Savoy Leaved. It matures during the same season as Bloomsdale or Norfolk Savoy, but stands about two week longer before bolting to seed, which is its feature. The plants are well crumpled and a good deep green color. Valuable for early use. 1 oz., 10c; $1 / 41 \mathrm{~b} ., 25 \mathrm{c}$.

Virginia Savoy Yellows or Iosaic Disease Resistant, A variety originated by the Virginia Truck Experiment Station, a cross between Resistant Bloomsdale Savoy and Manchurian. This is a cool weather variety, for winter in the South and fall in the North. The leaves have markedly the Savoy characteristics. 1 oz., $10 \mathrm{c} ; 1 / 4$ lb., $25 \mathrm{c}$.

New Zealand. Produces leaves in great abundance tinroughout the summer, should be raised in heat and transplanted three feet apart each way into light rich soil. 1 oz., $10 \mathrm{c} ; 1 / 4$ lb., $25 \mathrm{c}$.

King of Denmark Spinach. Large flat tufts. Early. Good keeper. Will stand 2 to 3 weeks longer than the very best lon's standing variety. 1 oz., 10c; 1/4 1b., 25c.

New Spinach (Princess Juliana). This is a new type of "Long Seaston" Spinach. The leaves are of good size, very dark green, well crumpled and thick. The first plants of Spinach to bolt to seed are the male plants. (Spinach is generally dioecious, i.e.: these are male and female plants.) This first bolting seed has been eliminated in this new race by the production of hermaphrodite plants, these plants seeding much later than male plants. 1 oz., 10c; 1/4 lb., $25 \mathrm{c}$.

\section{SALSIFY, OR OYSTER PLAN'T}

\section{Package 10 Cents}

German, Rocksbart; French, Salsifis; Spanish, Salsifi.

Yammoth Sandwich Island. 1 oz., $35 \mathrm{c} ; 1 / 4$ lb., $\$ 1.00$.

This very nutritious vegetable requires the same cultivation as Carrots or Parsnips. It is quite hardy and the roots may remain in the ground all winter; a quantity can be taken un and packed in earth or sand, and stored away for use when needed. It makes a fine soup, like the oyster. It is also half-boiled, grated fine, made into small balls, dipped inio butter, into small balls, dipped inio butter,
ne fried

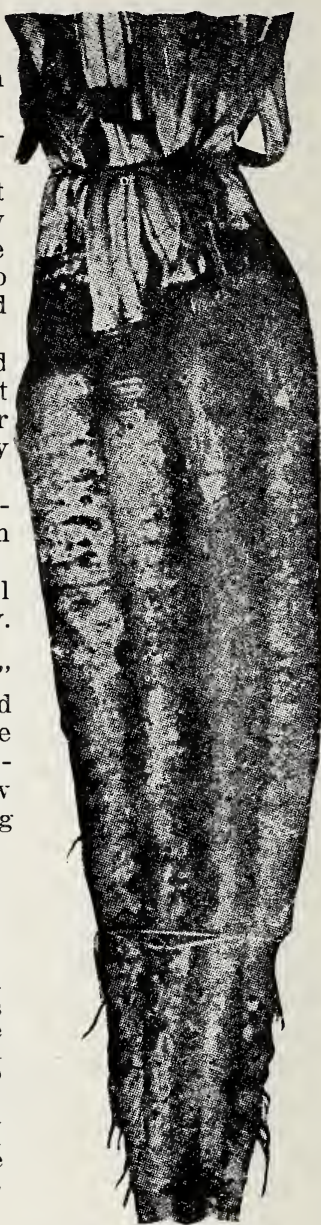

SQUASH-Package 10 Cents

Giant Yellow Summer Straight Neck. A selection from the Giant Yellow Summer Crook Neck Squash with all the good qualities of the former and none of its defects. There will be found in the new strain a small percentage that are not Crook Necks or Giant. The squashes are a deep orange color, heavily warted and when mature measure from 15 to 18 inches in length. The flesh is thicker and more meaty in the neck than in the Crook Neck variety. 1 oz. $20 \mathrm{c} ; 1 / 4$ lb., $60 \mathrm{c}$.

Hubbard. The best Winter Squash, fine grained, dry, keeps $60 \mathrm{c}$.

well and is of excellent flavor. Green. $1 \mathrm{oz} ., 20 \mathrm{c} ; 1 / 4 \mathrm{lb}$.,

Neapolitan Squash grows very long and slender, quite heavily curved, often scimitar in shape. The color is light green with smooth surface. It runs three to four incies in diameter, in fact this Squash reminds one of an eel. 1 oz., $75 \mathrm{c} ; 4$ oz., $\$ 2.75$.

Mammoth Summer Crookneck. Twice size of Summer Crookneck. 1 oz., 20c; 1/4 lb., 60 .

Early Golden Bush Scalloped. True bush growth producing fruit ready for use early in the summer. $1 \mathrm{oz} ., 20 \mathrm{c}$; $1 / 4$ lb., $60 \mathrm{c}$.

Early White Bush Scalloped. A white variety of the above. 1 oz., 20c; 1/4 1b., 60c.

Boston Marrow. A very valuable medium early variety, an excellent keeper and of superior quality, 1 oz., $20 \mathrm{c}$; $1 / 4$ lb., $60 \mathrm{c}$.

Golden Hubbard. The best Winter Squash, fine grained, dry, keeps well and is of excelient flavor. $1 \mathrm{oz} ., 20 \mathrm{c} ; 1 / 4 \mathrm{lb}, 60 \mathrm{c}$. 


\section{S()UISH-C'ontinned}

Ilammoth Chili. Grows to a large size, often weighing two husured pounds. Excellent for stock

Vegetable Marrow. A favorite English sort, skin greenish yellow, flesh white, soft and rich flavor...

Italian (Cocozella di Napoli). Grows 20 inches long with diametel of 3 or inches. Green or Marbled Yellow

Squashes are divided into two classes, Summer and Winter. The Summer varieties come into use about midsummer, and are eaten when the rind and the flesh are young and tender. The Winter varieties are kept on the vines until they are thoroughly ripe, gathered in the Fall, and stored away for Winter use. If well ripened and kept in a good cellar, they can be preserved until May. Prepare hill for the seeds by incorporating two or three shovelfuls of well rotted manure with the soil for each hill. For the bush varieties, from three to four feet each way, and for the running sorts from six to eight feet. Eight or ten seeds should be sown to each hill, thinning out after they have attained their rough leaves, leaving three or four of the strongest plants.

\section{SWISS CHARD OR SILVER BEET}

\section{Cents Package}

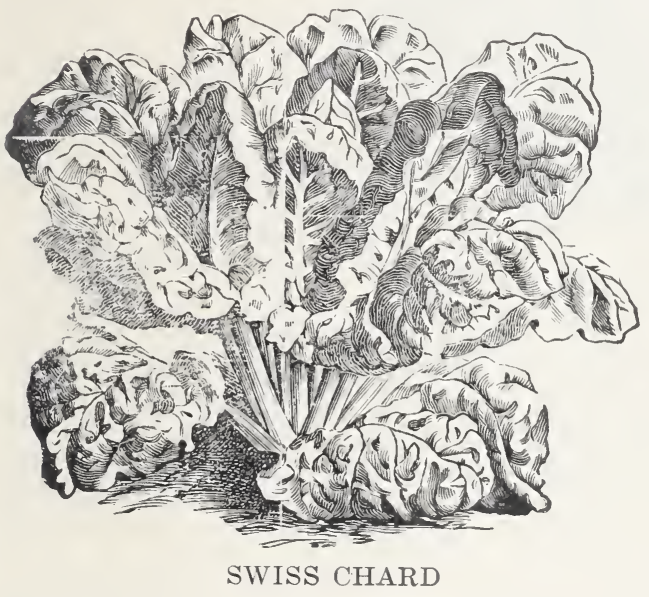

vilver Leaf. This is a Beet producing leaves only of a quality superior to those of the ordinary Beet, and excellent g:eens. ('ultivate about the same as spinach, by sowing in early spring in drills about a foot apart. 1 oz., 15c; $1 / 4$ lb., $45 \mathrm{c}$

Giant Lucullus. Large, crinkled leaves; tender and of fine flavor; dark green; pure white ribs. 1 oz., $15 \mathrm{c} ; 1 / 4$ lb., $45 \mathrm{c}$.

\section{TOMATO}

\section{Cents Package}

German, Liebesapfel; French. Tomate; Spanish, Tomata.

Break 0'Day. An early blight resistant Tomato introduced by Dr. Fred J. Pritchard of the United States Department of Agriculture by crossing Marvana and Marglobe. It possesses the small leafed open spreading type foliage of the Earliana, and produces smooth, mealy, globular red I. X. 1 . ruit similar to the Marglobe but larger

John liaer. Earliest tomato grown

Earliana, Extra Early. Bright red, smooth. It is claimed to be one of the earliest introduced, very productive.

Favorite. Large, smooth, productive, very solidand of fine flavor. A good shipper

Chalks Early Jewel. Extra early, large, smooth, tough skin, brilliant; solid

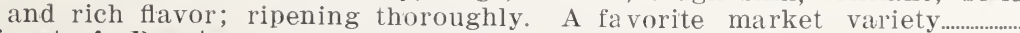

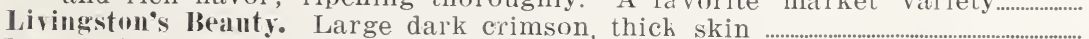

Wwari Champion. Resembles Acme, early

Icme A beautiful variety. Fruit of medium size, form perfect and very smooth. Ripens all over and through at the same time. This variety seems to possess all the good qualities that can be desired in a tomato...

Matchless. Extra large, smooth and handsome; bright red; very solid. Plant of vigorous growth and prolific.

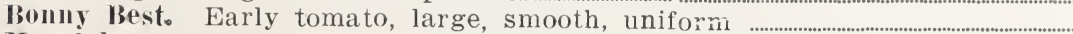

Marglobe. A new variety developed by the United States Department of Agriculture. Is very wilt resistant and is resistant to nail head rust. Fruit resembles Livingston's Globe but is scarlet and the fleh more solid. Vine dark green and vigorous...

$\begin{array}{rr}1.00 & 3.50 \\ .50 & 1.50 \\ .50 & 1.50 \\ .50 & 1.50 \\ & \\ .50 & 1.50 \\ .50 & 1.50 \\ .50 & 1.50 \\ .50 & 1.50 \\ & \\ .50 & 1.50 \\ & \\ .50 & 1.50 \\ .50 & 1.50\end{array}$




\section{TOMATO_Continued}

Yellow Plum. Used principally for pickling.

Red Pear Shape. Used principally for preserving and pickling

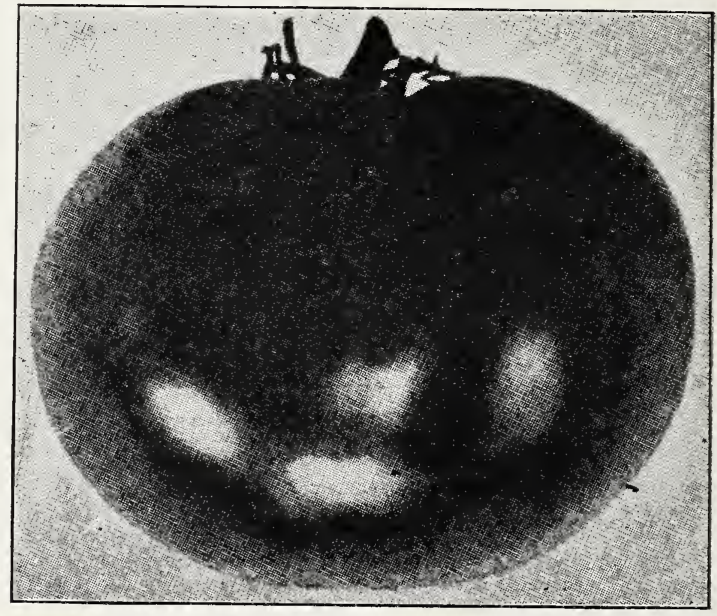

EARLIANA TOMATO

The seed should be sown in a hotbed about the first week in March, in drills five inches apart and half an inch deep. When the plants are about two inches high, they should be set out four or five inches apart in another notbed, or removed into small pots, allowing a single plant to a pot. About the middle of May the plants may be set in the open ground, at a distance of three to four feet apart in hills in wh:ch a good shovelful of rotted manure has been mixed.

\section{TURNIP}

\section{Cents Package}

German, Rube; French, Navet; Spanisì, Nabo.

Early White Flat Dutch. An early garden variety of medium variety size.........

$1 \mathrm{oz} .1 / 4 \mathrm{lb}$.

Red Top Strap Leaf. This and the preceding are the best two kinds for Spring sowing and for garden culture.

Red Top White Globe. Very desirable, extensively grown for market.

White Egg. A new variety, beautifully shaped; excellent table turnip

Yellow Globe. One of the best ror general crop, either for table use or stock

Yellow Stone. A good globe-shaped turnip, similar to the above 


\section{TURNIPS - Continued RUTA BAGAS}

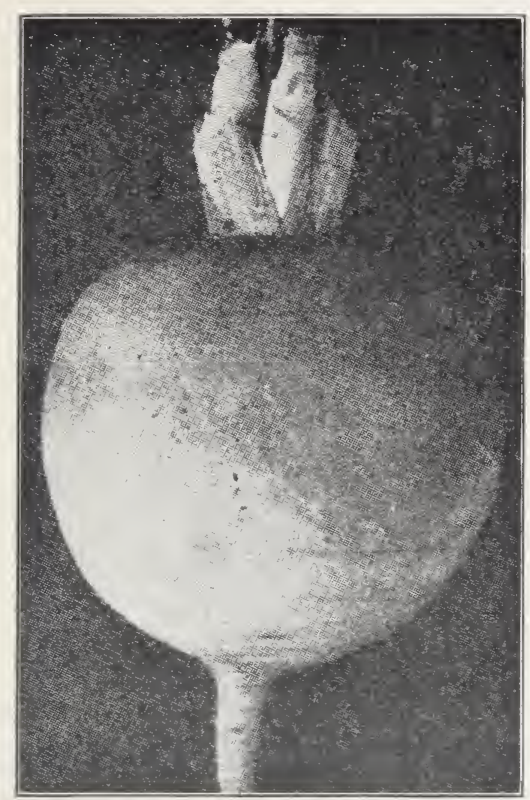

AM. IMP. PURPLE TOP RUTA BAGA TURNIP
Imerican Improsed Purple Top. The leading variety, of fine quality, valuable both for the table and for feeding stock. $1 \mathrm{oz}, 20 \mathrm{c} ; 1 / 4 \mathrm{lb}$. $50 \mathrm{c}$.

For spring crop commence sowing early varieties as soon as the ground can be worked, in drills fourteen inches apart; thin out the plants to five or six inches apart. Keep clear from weeds, and when the bottoms begin to enlarg, brush away the earth from about the roots the depth of an inch or more and give them a light dressing, of wood ashes. This is the surest mode of obtaining fair and smooth spring Turnips in old gardens where they are aimost certain to grow wormy if the earth is allowed to remain in contact with the roots. It is important to get them started very early so that they may have time to grow a sufficient size before very hot weather, when they will soon become tough and strong. For the Fall and main crops, sow from middle of July to the last of August in drills as directed for the Spring sowing. In the field, Turnips are more generally sown broadcast though much larger crops are obtained by drill culture.

\section{HERB SEEDS}

Herbs are valuable for culinary and medicinal purposes, but they do not always receive the attention which they deserve. Sow in Spring as soon as the weather is warm, and thin out as the plants grow up.
Anise (Pimpinella anisum), an annual cultivated for its seeds and its leaves, which are used for garnishing and ror seaoning....

Basil, Sweet. (Ocymum basilicum). This is a tender annual, cultivated for its leaves which are much used for flavoring soups and sauces

Borage (Borage officinalis), hardy annual, sometimes used as a pot herb, and also for garnishing, but chiefly for claret cup and other cooling drinks. Bees are very partial to the flowers

Caraway (Carum cauri), hardy blennial, cultivated for its seeds, which are largely used in various kinds of confectionery and for giving flavor to liquors.

Coriander (Coraindrum salivum), an annual, raised for its seeds, which are used by confectioners, and sometimes to disguise the taste of medicine

Dill (Anethum graveolens), annual, the leaves are used in soups and sauces, and the seeds are sometimes added to pickle cucumber to heighten their flavor. Medicinally they are good for flatulence and colic in infants. $1 / 41 \mathrm{~b} ., 50 \mathrm{c} ; 1 \mathrm{lb}$., 1.25

Sweet Fennel (Anethum foeniculum), hardy perennial, leaves used for garnishing and in the preparation of various fish sauces. Tall small foliage resembling dill. 1 lb., 1.75

Florence Fennel. An excellent salad plant and is also boiled. The flavor is somewhat spicy. Low growing. $1 / 4$ lb., $.60 ; 1$ lb., 1.75

Horehound (Marribium vulgare), hardy perennjal

Lavender (Lavandula spica), a popular aromatic herb

Marjorum, Sweet (Origanum Majorana), for seasoning:

Rosemary (Rosmarinus officinalis), an aromatic herb

Rue (Ruta graveolens), used for medicinal purposes, also frequently given to fowls for the roup

Sage (Salvia officinalis), much used for flavoring articles of cookery. It is also possessed of medicinal virtues. Tea made from its leaves is a soporific; causing profuse perspiration

Pkg.

Summer Savory (Satureia hortensis), annual. It has medicinal and culinary uses. Its aromatic leaves are much esteemed in salads and soups

Thyme. Brond Laved English, hardy perennial Thyme is used in various ways for soups, sauce and dressings, and a tea is made of the leaves which is a great remedy for nervous headaches
.10

$\mathrm{Oz}$. 


\section{GENERAL LIST OF FLOWER SEEDS}

The following list contains a most complete assortment of the choicest and most popular flowers for either conservatory, greenhouse or garden culture.

Annuals grow from seed, flower, mature their seed, and die in one year, or, in other words, the same season.

Hardy Anmuals are those which can be sown in the open ground.

Hali-Hardy Annuals are those which should be started early in the house, conservatory or hotbed, and transplanted to the garden in settled warm weather.

Biennials grow from seed, sown from June to August, flower, ripen their seed and die the next year, though some varieties bloom the same season if sown early in gentle heat.

Hardy Biennials will winter in the open ground without protection.

Perennials grow from seed, and continue flowering annually for many years after the first season. Some varieties flower the first season if planted early in gentle heat.

Hali-Hardy Biennials require the protection of a cold frame or cool house during winter.

Hardy Perennials can remain in the open ground during winter without protection. Winter.

Half-Hardy Perennials require the protection of a cold frame or cool house during the

Tender or Greenhouse Perennials require window or greenhouse culture, free from frost during Winter and thrive in the garden during the warm months.

\section{EXPLANATION OF FLOWER SEED ABREVIATIONS}

$\begin{array}{lcl}\text { H.A. designates } & \text { Hardy Annuals } \\ \text { H.H.A. } & \text { “ } & \text { Half-Hardy Annuals } \\ \text { H.B. } & \text { “ } & \text { Hardy Biennials } \\ \text { H.H.B. } & \text {. } & \text { Half-Hardy Biennials } \\ \text { H.P. } & & \text { Hardy Perennials }\end{array}$

H.P.

ABRONIA umbellata. H.A. Trailing annual, pink flower trusses. $9 \mathrm{in}$.

$$
1 / 4 \text { oz., 2c. } .10
$$

MCHLLLA ptarmica. "The Pearl." H.P. Double white flowers

ACONITUM napellus. H.P. Dark blue flowers in August

ACROCLINIUM, Double Finest Mixed Colurs. H.A. Pretty everlasting flowers; fine for Winter bouquets. $1 \mathrm{ft}$. $1 / 4$ oz., $20 \mathrm{c}$.

AGLRATUM。 H.A. Blooms throughout the Summer; feathery flowers in clusters.

nanum "Blue Ball." Compact, ball shaped plants, of unusual uniformity. 6 in. ......................................................... oz., $50 \mathrm{c}$.

Little Dorrit Blue. Flowers bright blue. 6 in. $1 / 4$ oz., $30 \mathrm{c}$

Little Dorrit White. Pretty for contrast. 6 in. ........................................................

\section{AGROSTEMMA.}

coronaria (Rose Campion). H.P. Crimson flowers, silver foliage. $2 \mathrm{ft}$.

$1 / 4$ oz., $35 \mathrm{c}$

ALYSSUM. H.A. Pretty little plants for beds, vases, baskets, edgings or rock work; blooms profusely all summer.

maritimum (Sweet Alyssum). Fragrant, white; flowers all Summer. 6 in.

1 oz., 30c.

Benthami Compactum, Lilac Queen.Pure lilac flowers, dwarf and compact growth. 6 in. ...................................1/4 oz., $25 \mathrm{c}$.
H.H.P. designates

H.C.

G.P.

H.A.C.

Half-Hardy Perennials

Hardy Climber

Greenhouse Plant

Hardy Annual Climber

ALYSSUM-Continued

procumbens (Carpet of Snow). Dwarf; pure white. 4 in...............................1/4 oz., $25 \mathrm{c}$.

Pkt.

saxatile compactum. H.P. Spring blooming Alyssum with yellow flowers. 12 in. ........................................................................1 oz., 75c.

.15 AMARANTHUS. H.A. Ornamental foliage plants, producing a striking effect either in the conservatory or flower garden.

candatus (Love-lies-bleeding). Long drooping crimson spikes. $3 \mathrm{ft}$. $1 / 4$ oz. $25 \mathrm{c}$.

cruentus (Priuce's feather). Daik red feathery flowers. $3 \mathrm{ft}$...............1/4 oz., 35c.

tricolo' (Joseph's Coat). Leaves red, yellow and green. $2 \mathrm{ft} . . . . . . . . . . . .1 / 4$ oz., $35 \mathrm{c}$.

Yolten Fire. Leaves dark bronze, center poinsettia red dwarf, beautiful. $1 \frac{1}{2} \mathrm{ft}$. 1-16 oz., $\$ 1.00$

AMPLLOPSIS Veitchi (Japanese Woodbine, or Boston Ivy). H.C.... 1/40z., 40c.

ANCHUSA capensis. H.A. Flowers resembling large Forget-me-nots. 18 in. $1 / 4$ oz., $75 \mathrm{c}$.

grandiflora (Dropmore Variety). H.P. Large flowered, dark blue. $5 \mathrm{ft}$. $1 / 4$ oz., $50 \mathrm{c}$.

Annual, Blue Birl. (New), compact indigo blue. ...............................................1/4 oz., 50c.

ANTHEMIS Kelwayi. H.P. Yellow flowers. $3 \mathrm{ft}$................................................1/4 oz., $75 \mathrm{c}$.

INTIRRHINUM Maximum, New Giant Flowered. H.H.B. This new class of 
ANTIRRHINUM-Continned

Antirrhinums is attracting much admiration and well deserves it. The flowers are of extraordinary size and entirely distinct from anything what has been produced in Antirrhinums so fai. In order to obtain best results plants should be staked. Three foot.

Cerberus. Rich carmine red... $1 / 4$ oz., $75 \mathrm{c}$. Gotelind. Bright orange............1/4 oz., $75 \mathrm{c}$. Purple King. Rich purple..........1/4 oz., $75 \mathrm{c}$. Camary Bird. Pure soft canary yellow $1 / 4$ Oz., $75 \mathrm{c}$.

Defience, Scarlet .............................1/4 oz., $75 \mathrm{c}$.

Fascination. Deep flesh pink...1/4 oz., $75 \mathrm{c}$.

Snowflake. Lovely pure white with yellowish throat .................................1/4 oz., $75 \mathrm{c}$.

('opper King. Coppery scarlet turning into a pure copper color...... $1 / 4$ oz., $75 \mathrm{c}$.

Wal!flowered Colored. Rich Mahogany red $. .1 / 4$ OZ., $75 \mathrm{c}$

AQUILEGIA (Columbine). H.P. Fine free flowering, hardy border plantone of the most desirable perennials. Seed may be planted in tine open ground early in Spring and will in some varieties bloom in the same season. Best results, however, are obtained by planting in August for the next season's blooming.

Longspurred Hybrids (Mrs. Scott's Strain). Very large flowered and most beautiful color proportion. Mixed. 1 oz., $75 \mathrm{c}$.

ehrysautlaa (golden spurred). Long spur red golden yellow. $2 \mathrm{ft} . . . . . . .1 / 8$ oz., $75 \mathrm{c}$. (oerulea (Rocky Mountain Columbine). Large flowers, violet blue and white. 2 ft. ......................................................... $1 / 4$ oz., $75 \mathrm{c}$. coerulea. Mrs. M. Nicholl's

1-16 oz., $\$ 1.00$.

Jaetschani (Rare). Very large yellow with red spurrs. 3 ft.......1-16 oz., $\$ 1.00$ ARARIS Alpina. H.P. Excellent for borders or rock work. Pure white. 6 in. $1 / 4$ oz., $30 \mathrm{c}$.

ARCTOTIS grandis. H.A. Daisy-like flowers; white shaded blue. $2 \mathrm{ft} . . .1 / 4$ oz., $35 \mathrm{c}$.

\section{ISTERS}

Plants from seed sown in the open ground in May bloom finely in September and October, when the flowers are seen at their best. For July and August flowers sow in March or April, in coldframe, spent hotbed, or pots and boxes in the house. Cover the seeds about half an inch deep with rich light soil, and when the plants have three or four leaves, transplant about 18 inches apart each way into well prepared beds.

GIIN'TS OF CILIFORNIA. An improved form of Crego with flowers 6 inches across packed with broad petals. $2 \mathrm{ft} \quad 1 / 4$ oz. Pkt.

Dark Purple

Peach Blossom $\$ 0.85 \$ 0.15$

Light Blue

Liglit Purple $.85 \quad .15$

White

Finest Mixed
Pkt.

Pkt. climber, profuse red flowers. 10 ft

BELLIS perennis tl. pl. (Double English Daisy). H.P. Spring-flowering perennial. 6 in.

monstrosa gigantea. These surpass all strains of this popular plant in strong robust growth and in the abundance of extra large, perfectly double flowers.

11ka Giant white ...................... ${ }^{1 / 8} \quad 07 ., \$ 1.00$ Rosea Giant lose ................... ${ }^{1} 8$ oz. $\$ 100$ Etua. Giant flowered red quilled $1 / 8$ OZ., $\$ 1.00$ Ilixed ……...................................... $1 / 8$ oz., $\$ 1.00$

BIUE I ICE FIOWERS. (See Didiscus caerulea).

BOSTON IVT (See Ampelopsis)

BROW ILIII Speciosa Major. Ultramarine. A plant used in the border, hanging-basket; especially valuable as a pot plant for winter blooming.

Vick's Branching). Flowers Branching fouble and fine form.

('rimson $\$ 0.50$

shell pink

Blue

Purple ............................................................................... $\quad .50$

MRIOLA ISTERS

ins (Needled type). Upright growth;
large flowers, long narrow petals. 2 inushime Twisted and quilled petals. Fine for cutting, as the flowers last a

Early Wonder (Express). Extra early. fow quite double, good size on stiff

llpinus lougepetale (Perennial Aster, or Michaelmas Ddisy). H.P. Star-like, flowers with large yellow center. $1 \mathrm{ft}$.

.


BUTTEREL FLOWER (See Schizanthus).

CALCEOLARII hybrida grandiflora "James Strain." G.P. Highly prized plants for conservatory and house decoration

CALENDULA (Pot Marigold). H.A. Free and continuous flowering garden plants. 12 in.

Campfire. (Sensation.) The best orange with red sheen and yellow center. $1 / 4$ oz., $\$ 1.00$

Radio. Flowers very full, petals quilled; rich glowing orange color... $1 / 4$ oz., $60 \mathrm{c}$.

Ball's Improved. Extra double, bright orange, free flowering............1/4 oz., $\$ 1.00$

Lemion Queen. Sulphur yellow...1/4 oz., 7 j̃c.

Mammoth Orange ............................1/2 oz., 25c.

CALLIOPSIS. H.A. Nothing is more effective than a bed of these golden flowers.

Radiata (Golden Ray). Pure yellow flowers, very large and showy. $10 \mathrm{in}$.

bicolor nana purpurea (Crimson King). Deep bright scarlet. $1 \mathrm{ft} . . . . . .1 / 4$ oz., $20 \mathrm{c}$.

CAMPANULAS. H.P. All the campanulas can be grown in ordinary gardens and will flower from seed the following year

carpatica. Deep blue; for rockeries, beds and edgings. 6 in.........1/4 oz., $50 \mathrm{c}$.

carpatica alba. Flowers white...1/4 oz.. 50c.

pyramidalis. (Chimney Bell). Very conspicuous towering spikes, with clear blue flowers. $4 \mathrm{ft}$..........1/4 oz., $60 \mathrm{c}$.

pyramidalis alba. Pure white. $4 \mathrm{ft}$. $1 / 4$ oz., $60 \mathrm{c}$.

persicifolia coerulea blue (Peach Bells). Fine hardy bell flower. 11/2 ft. $1 / 8$ oz., $75 \mathrm{c}$.

longistyle. Fine perennial rock plant.

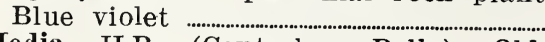

Media. H.B. (Canterbury Bells). Oldfashioned hardy biennials; splendid for borders or naturalizing in the wild garden. $2 \mathrm{ft}$.

Single Mixed Double Mixed ………....................... $1 / 4$ oz., $20 \mathrm{c}$.

Calycanthema (Cup and Saucer). A splendid variety with large semi-double flower resembling a cup and saucer. Fine for cut flowers and border use. $2 \mathrm{ft}$. Mixed ........................................1/4 oz., 60c.

CANARY BIRD VINE. H.A.C. Pretty climber, with yellow butterfly-like flowers. $10 \mathrm{ft}$................................... oz., $50 \mathrm{c}$.

CANIYTUFT. H.A. Showy plants, much grown in masses for bedding and edgings.

coronaria Giant Hyacinth-flowered. Select. Pure white, from 10 to $12 \mathrm{im}$ mense spikes on a single plant. $12 \mathrm{in}$.

odorata (pectinata). Sweet $1 / 2$ oz., $30 \mathrm{c}$. 10 in. .....................................................1/2 oz., 30c.

sempervirens. H.P. White flowers. 12 gibraltarica. H. P. Beautiful bluishwhite. 12 in.
Pkt.

CANTERBURY BELLS. H.B. (See Campanula media).

CARDINAL CLIMBER. H.A.C. (See Ipomoea cardinalis).

CARNation. Chabauds Perpetual Flowering: H.H.P. A distinc strain of Carnation, with v $e_{i} y$ läige llowers of the finest texture. Biooms within six months from seed and cositinues to bloom throughout the Summe: The plants are robust, erect growing habit and produce a large number of flowerin stalks. 18 in.

Jeanne Dionis. Pure white

1,3 oz., $\$ 100 \quad .15$

Marie Chaband Cell jw.......

Rose Qucen. Rosy Pink........, oz., $\$ 1.00 \quad .15$

Nero. Crimson .........................1/8 oz., $\$ 1.00 \quad .15$

Marguerite H.H.P. Flowers large and fragrant .........................................1/8 0z., 50c.

Grenadine Double scarlet. Ve:y early flowering. $1 \mathrm{ft}$........................1/4 oz., $\$ 1.00$

Finest Double Mixed Border Gives a slight mulch. $1 \mathrm{ft}$.....................1/4 oz., $\$ 1.00$

Early Dwarf Vienna. Double Mixed. $1 \mathrm{ft} . . . . . . . . . . .1 / 4$ oz., $75 \mathrm{c}$.

CASTER BEANS (See Rincinus).

CELOSIA Cristata. (Cockscomb.) H.H.A. Popular annual of easy culture producing Cockscomb-like heads.

Glasgow Prize. Large, deep crimson. 12 in. ...............................................1/8 oz., $65 \mathrm{c}$.

Fire King. Fiery red.......................1/8 oz., $65 \mathrm{c}$.

Dwarf. Mixed colors, extra fine strain. 9 in. ...................................................1/4 oz., $\$ 1.00$

CELOSI Childsi (Chinese Wool Flower). A variety of feathered Celosia with large globular flowers like balls of wool. 2 ft. ................................1/8 oz., $35 \mathrm{c}$.

CELOSIA plumosa. (Ostrich Plume). H.H.A. Producing large, graceful plumes, makes fine plants for large beds or groups, and the rowers or plumes can be dried for Winter bouquets. $3 \mathrm{ft}$.

Triumph of the Exposition. Bronze colored foliage. Feathery plumes of crimson. 24 in. ............................1/4 oz., $75 \mathrm{c}$.

Pride of Castle Gould. Immense flower heads. Colors are blood red, carmine, yellow, orange, golden orange, scarlet in mixture. Branching habit. $2 \mathrm{ft}$. $1 / 8$ oz., $\$ 1.00$

CENTAUREA. candidissima. (Dusty Miller.) H.A. Round compact plants, white leaves broadly cut. 12 in.

CENTAURE\. montana。 H.P. (Hardy Cornflower). Large flowers of deep blue, very showy. $2 \mathrm{ft........1/8}$ oz., $35 \mathrm{c}$. suaveolens (Yellow Sweet Sultan). An outstanding variety with fine soft yellow flowers on long stems. For outdoor or conservatory use it is unsurpassed. 18 in. ..................................1/4 oz., $50 \mathrm{c}$.

CENTAUREA. cyanus. (Bachelor Button, Cornflower, Blue Bottle or Ragged Sailor). H.A. This is one of the most popular annuals; will grow in the poorest soil, eitner on seashore or 
CENTILREA-Continned

mountain. 18 inches.

Double Blue (Florist's Strain). Fine for cutting ...........................................1 oz., 75c

Naila compacta Vicetoria. Dwarf. $1 \mathrm{ft}$.

Finest Double Mixed ....................1/4 oz, $25 \mathrm{c}$.

CENTIUREA imperialis. Giant Imperial Sweet Sultan. H.H.A. Fine for massingr in borders and are unsurpassed for cut flower purposes. They also respond to indoor culture and provide a long succession of bloom for Winter decoration. $32 \mathrm{in.}$

Favorita Rose, Bright rose......1/4 $\quad$ oz., 30c. $\quad .10$

Grazioza. Lilac ..................................1/4

Splendens. Dark purple.............1/4 oz., 30c. .10

CERASTIUM tomentosum. (Snow-in-Summer). H.P. A dwarf, white-leafed edging plant with small white flowers. Good rock plant. 6 in....1/8 oz., $75 \mathrm{c}$.

CHEIRINTHES allioni (Alpine walifiower). H.H.P. Excellent for rockery or border; brilliant orange flowers. 9 in. Very fragrant .................................1/4 oz., $\$ 1.00$

linilolius. This charming lilac Wallflower is seldom out of flower. Valuable for hardy borders and rock gardens. $1 \mathrm{ft}$.

CHRYS INTHEMUM. carinatum double hybrids. H.A. Showy, hardy annuals of easiest cultivation, blooming from July until frost. 1 to $11 / 2 \mathrm{ft}$.

$1 / 2$ oz., 30c.

leucanthemum lo y b rid u m. (Shasta Daisy). Pure white, early flowering spring marguerite. $11 / 2 \mathrm{ft} . . .1 / 4$ oz., $50 \mathrm{c}$.

maximum. "The Speaker." Very large snow white flowers. Free flowering. $11 / 2$ ft. ..............................................1/8 oz., $75 \mathrm{c}$.

CINERIRIA hybrida. G.P. One of the most gorgeous colored flowering plants for either greenhouse or conservatory. Seeds should be sown in July, August or September.

Innltiflora nana (Berlin Market strain). Very dwarf and compact. Flowers of large size, a good pot plant. Mixed colors. 9 in.

multiflora grandiflora maxima. This new Hybrid is a cross between multiflora nana and grandiflora; flowers extra large, measuring 2 to 3 inches in diameter and produced in quantities of 100 blooms and over to a plant; mixed colors

CINERIRIA maritima candidissima. H.H.P. A whiteleaved "Dusty Miller" used for edging. $1 \mathrm{ft} . . . . . . . . . . .1 / 4 \quad 0 z ., 35 \mathrm{c}$.

CLARKIA. H.A. This pretty and easily grown annual does well either in sun or shade. $2 \mathrm{ft}$.

Brilliant. Double salmon-scarlet flowers

Chieftain. Extra double mauve.

$1 / 4$ oz., 25c. .10

Apple Blossom. Soft pink.........1/4 oz., 25 c. $\quad .10$

White ….....................................................1/4 oz., 25c. $\quad .10$

Double Yixed ...........................................1/4 oz., 25c. $\quad .10$

Pkt.

.10
DAII sealed packages......100 seeds, $\$ 2.75$ can be easily raised from seed, flowering the same season. Seed should be sown early in gentle heat. 4 to $6 \mathrm{ft}$.

Decorative and Cactus Mixed. Includes Decorative and Cactus Hybrids, Eng-

Pkt. rosy-crimson flowers; adapted for large beds or borders.

COB\EI scaudens. H.A.C. Tender climber, large, bell-shaped blue flower. $20 \mathrm{ft}$..............................................1/4 Oz., $25 \mathrm{c}$

COCKSCOMB (See Celosia cristata).

COLEUS. Iyluridus. G.P. Richly colored foliage plants. Finest mixed.........................

Hybrilus. Large-leaved. Brilliant crimson-red, charming .

COLUMBINE (See Aquilegia)

CONVOLWULUS, or Morning Glories (See also Ipomoea).

COREOI'SIS. H.P. Long stemmed, large, single flowers. $2 \mathrm{ft}$. Fine cut flower.

Gramditlora. Large flowers of rich yellow

grandiflora fl. pl. An improved type with large double flowers of deep yellow...

CORNFLOWER (See Centaurea cyanus).

(OSMOS. H.A. This is one of our most useful and beautiful autumn flowers. To get it in bloom early, seed should be sown in May in the open ground where the plants are desired to bloom, and the seedlings allowed to grow and flower without being transplanted. $5 \mathrm{ft}$.

louble-crested. Early-flowering Semidouble flowers in great profusion. 5 ft. Nixed colors .........................1/4 oz., $75 \mathrm{c}$.

Extra Early Giant-flowering. Flowers 4 to 5 in. across. $4 \mathrm{ft}$.

Crimson $1 / 4$ oz. $25 \mathrm{c}$. Pink ……....................................................1/4 OZ., 25c. White .........................................................1/4 oz., $25 \mathrm{c}$. Mixed …...............................................1/4 oz., 25c.

New Early Express. A new very early flowering Cosmos which produce flowers from seed in forty-five days. White, Crimson, Pink ............1/4 oz., $75 \mathrm{c}$.

COWSLIP, Mixed (Primula Veris). H.P. A spring-flowering plant. Beautiful colors, rich brown, crimson and yellow. 6 in. rich blue, sweet-scented flowers. Fine for cutting. $18 \mathrm{in}$.......................1/4 $\mathrm{Gz}, 50 \mathrm{c}$.

CYPRESS VINE. H.A.C. A fast growing annual vine, with feathery, dark-green foliage and star-like flowers $10 \mathrm{ft}$.

Bright Scarlet ........................................1/4 oz., 25c. Finest IIixed ..........................................1/4 oz., $25 \mathrm{c}$

CYCLIVIEN. G.P. Giant Show. Seed should be sown from August until January. The seeds we offer are grown by Binnewies in Europe, who, we believe, has the finest strain for exhibition plants. Best colors, original sealed packages......100 seeds, $\$ 2.75$

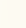


DIHLIA-Continued

lish and American types, 45 newest and best exhibition varieties

DAISY, Double (See Bellis Perennis).

DAIST, single (See Chrysanthemums).

DELPHINIUI (Larkspur). H.P. Delphiniums are hardy and can be grown in any garden. They are handsome plants for the herbaceous border and shrubbeiy and are splendid for cut flower use.

Wrexiam oi Hollyhock Hybrids. Experis regard this strain as quite the finest in cultivation. It is conspicuous for its massive, broadbased spires of large individual flowers which are compactiy airanged about the stems. The shades of blues and mauves are of exquisite clarity. 4 to $6 \mathrm{ft}$....

Belladonua, Fanny Stormonth. Light azure blue.

Blue Butterfly. Long spikes of azure blue flowers. $3 \mathrm{ft}$.........................1/8 oz., $\$ 1.00$

Formosum. Loose spike flowers about a foot long, deep blue...................1/8 oz., $\$ 1.00$

Cardinale. Scarlet

Sulphureum. (zalil). Yellow, orchid-like flowers. $6 \mathrm{ft}$.

selecta Iouble. A very choice strain. Very large flowering

Hixed. A mixture of perennial varieties ...............................................1/4 oz., 25c.

UINTHUS. HARDY ANNUAL PINKS. Chinensis, China or Indian Pinks. Single or double ..................... 1/4 oz., 30c. Heddewigii Hybridus (Japanese Pink). Double mixed ..................................1/4 oz., 35c.

sweet Wivelsfield (Dianthus Allwoodii $x$ D. Barbatus). A new hardy Annual, good for borders, as a cut flower, and especially adapted for rock gardens......

HARIY GARDEN PINKS. Allwoodi. Double clove scented. Mixed..

Plumarius (Grass or Scotch Pinks). A beautiful single with fringed edge. Flowers of various colors......1/4 oz., $35 \mathrm{c}$. plumarius nanus fl. pl. Double early flowering hardy garden "Pinks." 10 in. Fringed ...................................1/4 oz., 50c. Semperflorens. (Florists' Perpetual Pinks). 16 in...................................1/4 oz., 35c.

DIJISCUS. Caemlea (Blue Lace Flower). H.A. An attractive annual blooming from July until frost. Pale lavender flowers. 18 in. .............................1/8 oz., $50 \mathrm{c}$.

IIGITALIS or FOXGLOVE. H.P. Producing long spikes of tubular flowers. Used extensively with good effect for naturalizing in shrubberies and half shady places.

The Shirley. (New). Very large flowered spotted, mixed. $4 \mathrm{ft}$.

gloxiniaflora. Finest spotted varieties, mixed $1 / 4$ oz., 35c

DITORPHORTHECA. New Hybrid. H.A. Daisy-like blossoms of a rich orange color, dark disc surrounded by black zone. $11 / 2 \mathrm{ft}$..........................1/4. oz.. $50 \mathrm{c}$.

DOLICHOS or HY ACINTH BEAN. H.A.C. Annual climbers with clusters of beanlike flowers. Mixed. $10 \mathrm{ft......1} \mathrm{oz} \mathrm{,} 40 \mathrm{c}$.
Pkt. .35

ECHINOCYSTIS lobata (Wild or California Cucumber). H.A.C. The fastest growing annual vine in existence; twenty feet in six weeks. Pretty foliage and inconspicuous white flowers.

1 oz., 35c.

ESCHSCHOLZIA OR CALIFORNIA POP. PY. Fi.A. Very attractive annuals for beds, edgings, masses, profuse blooming, fine cut, glaucous foliage blooms from June until frost. $1 \mathrm{ft}$.

Carmine King, Deep Carmine...1/4 oz., $25 \mathrm{c}$. Golden Wesi. (California). Yellow with orange center .................................1/4 oz., $25 \mathrm{c}$.

Taugo. Bronzy red overlaid terra cotta ..........................................................1/4 oz., 25c.

Enchantress. Double Pink......1/4 oz., $25 \mathrm{c}$. Hybrida Mixture. Made up of new colors in Eschscholtzias and inciudes soft pinks, scarlet, chrome, copper red, claret and royal purple.

$1 / 4$ oz., 25c.

EUPHORBIA. Strong growing annua s, suitable for beds of fall-growing plants or mixed borders. The foliage is exceedingly ornamental. Sow outdoors in April.

Variegata (Snow-on-the-Mountain). Elegant, bushy plants, with broad green leaves, veined and margined with white. Attractive in foliage groups. Height $2 \mathrm{ft}$.........................................1/4 oz., $25 \mathrm{c}$.

Heterophylla (Annual Poinsettia; Mexican Fire-Plant). An annual, bushy plant, with highly ornamental leaves, which in Summer and Autumn become dark fiery scarlet. Height $2 \mathrm{ft}$. to 3 ft. .......................................................1/4 oz., $35 \mathrm{c}$.

50 EVERLASTING FLOWERS. The Straw Flower (Helichrysum) is perhaps better known than the other sorts listed, but all are fully as interestin: fö giving variety to dried winter bouquets. These make fine gifts from your own garden to your friends. The drying is a simple operation; cut before fully expanded, bunch like sweet peas, and hang on a line upside down in a cool, dark, dry room. It takes ten days. Sow seed indoors in March; outdoors in May, in a sunny spot.

Acroclinium, Iixed. H.A. Pretty white and rose, daisy-like flowers, so desirable for Winter bouquets. Height 1 ft. .............................................................1/4 oz., 20c.

Globe Amaranth, Mixed (Gomphrena). H.A. Flowers of white, pink, rose, and purple, like heads of clover, but are Straw Flowers. Height 1 ft. $1 / 4$ oz., $20 \mathrm{c}$.

Helichrysum monstrosum, mixed (Straw Flower). H.A. Height $2 \mathrm{ft} . . .1 / 4$ oz., $25 \mathrm{c}$. Physalis (Chinese Lantern PIant) Fanchetii. H.P. Hardy perennial forming dense bushes about 2 feet high, producing bright orange scarlet lantern-like fruits. May be had in flower first year from seed if seed is sown early: the fruits are often displayed in 
EVERLASTING FLOWERT-Continued Pkt. florist shops and are very interesting, and of splendid decorative value.

$$
1 / 4 \text { Oz., } .15
$$
splendid decorative value.......1/4 oz., $50 \mathrm{c}$. $\quad .15$

Rhodanthe, mixed. H.A. Neat. slender plants with silvery leaves and dainty lavender, pink, and white flowers like inverted cones. $1 \mathrm{ft} . . . . . . . . . . . . .1 / 4 \quad$ oz. $35 \mathrm{c}$.

statice (Sea Lavender) Latiolia H.P. The cloud-like masses of flowers of the branching varieties make borders gay for a long time, while their delicate coloring and light, graceful habit are a great help to helichrysums and other everlasting flowers. Hardy perennial, purplish blue flowers.

$1 / 4$ oz., $50 \mathrm{c}$.

Serantlemum annum, mixed. H.A. Showy rose, purple and white daisylike flowers with an outer corolla and a cup in the center...................1/4 oz., $50 \mathrm{c}$.

FEVERFEW (See Matricaria).

FORGET-IE-NOT (See Myosotis).

FOLN'TII PI.IN'T (See Amaranthus)

FOLR 0'ClOCK. Marvel of Perly. This is another good old-fashioned annual flower of bushy habit, bearing hundreds of white, yellow, crimson and violet flowers during the season. Very charming when used as a hedge plant, with its glossy foliage very closely set and dotted all over with flowers in the afternoon. Height $2 \mathrm{ft}$. Sow seed outdoors in April in a bright sunny location.

Fine Vixed 1 oz., $25 \mathrm{c}$

FOXGLOYE (See Digitalis).

GAILIARDIA. H.A. Showy garden annuals they flower uninteruptedly from early Summer until frost. The flowers are of large size and afford charming tints in their color. $2 \mathrm{ft}$.

Picta Indian Chief. An annual bronzy red variety given the Award of Merit 1929. $1 / 4$ oz., $35 \mathrm{c}$

Picta Lorenziana Annual double mixed. $1 / 4$ oz., $35 \mathrm{c}$

Portola Hyirids, Varied shaues of redtipped golden. Long, stifi stems. $1 / 4$ oz., $50 \mathrm{c}$.

Dazrler: Golden yellow and maroonred ................................................... $1 / 4$ oz., $50 \mathrm{c}$

Tangerine, Medium size flower. Graceful in appearance and a fine cutflower. ..................................................1/4 oz., 35c.

Fine Mixed $1 \mathrm{oz} ., 75 \mathrm{c}$.

GEYTIIXI acaulis. H.P. Deep blue flowers. Suit to moist shady situations. 5 in.

GERBERI Jamesoni Hybrids H.H.P. (The Transvaal Daisy). H.H.A. Fine for cut flowers or bouquets. 18 in. 100 seeds $\$ 1.00$

GELYY H.P. Showy hardy perennial of easy culture, and well adapted for the garden; fine for cutting. $2 \mathrm{ft}$.

Mrs. Bradshaw. Double-orange scarlet flowers, very large and full.

Lady Stratheden. Double yellow flowers. GLORE-IIIRIXTH ( GOYPHRENA).
(See Everlasting Flowers).

GOURIS. H.A.C. Thrifty annual climbers, bearing "Ornamental Gourds." Bottle, Dipper, Dishcloth, Egg Shaped, Calabash, Hercules' Club, Nock Orange, Nest Egg, or Mixed.........1 oz., 35c.

GRISIEX ORYIMENTIL. A most valuable class of plants for the lawn shrub bed or tropical bed. The perennial varieties, many of which have variegated foliage, are excellent. The annual sorts are particularly pretty on account of the graceful, feathery flower panicles.

Imunol Varities. ('loud, Quaking, Love Purple, and Purple Fountain Grasses and Job's-tears.

lerenuinl Varities Pampas Zebra, Fea-

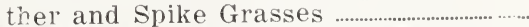

GIPAoPIII.I (Baby's Breath). H.A Extremely useful for bouquets. Flowers small and come in delicate sprays and panicals.

elegans Covent ciarlen. An improved large flowering pure white form of "Elegans." $11 / 2$ ft.........................1 oz., 35c elegans mixed. $1 \frac{1}{2} \mathrm{ft}$....................... I oz., $25 \mathrm{c}$. paniculata. H.P. One of the finest for cutting. Pure white flowers very small and borne in large panicles. 2

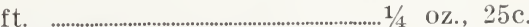

paniculata flore pleno. H.A. A double flowering variety, pure white. $2 \mathrm{ft}$......

HEIIINTHCS (See Sunflower)

HEIICHRISUI (See Everlasting Flowers).

HELIOTROPE Queen Marguerite, Magnificent early and free-flowering dwarf compact habit, gigantic sweet-scented flowers. Dark blue

HESPERIS (See Sweet Rocket).

HIBISTUS afrioanus. H.P. 4 to 6 inch bowl-like flowers. Yellow with black center. $11 / 2$ ft.................................1/4 oz., $25 \mathrm{c}$

HOLIVHOCKS. H.P. One of the showiest of hardy garden plants. No garden is complete without these stately flowers Hollyhocks are troubled of late with a rust which can be prevented if plants are sprayed frequent ly in early Spring with Bordeaux Mixture.

Charter's Prize Early Iouble Iilac. Crimson ……..........................................1/8 oz., 55c. ('herry .................................................1/8 oz., 35c. Rosa ........................................................1/8 oz., 35c.

Tilac, purple eye .........................1/8 oz., "35c Sulphur-yellow ...............................1/8 oz., $35 \mathrm{c}$. Hybrids. Everblooming annual, mixed. $1 / 4$ oz., $40 \mathrm{c}$.

Double Begonia Flowered, mixed

HONESTY. Seed should be sown late in the spring to produce seed pods for winter decoration. ....................1/4 oz., 35c.

HIMUIS J.IPONTCUS (Japanese Hop). H.A.C A climber with dense green foliage. $20 \mathrm{ft}$............................1/4 oz., 35c.

HENTEYIXYI fmmariaefolia. (Giant Yellow Tulip Poppy). H.A. Flowers are tulip-shaped, pure golden yellow 


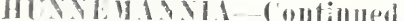
When cut and put in water they will last a week. $2 \mathrm{ft}$.......................1/4 oz., $25 \mathrm{c}$.

Pkt.

HIIYIXTH PBEAY (See Dolichos).

ICE PI.INT. (Mesembryanthemum Crystalinum). H.H.A. A dwarf trailing annual plant; flowers white; singular icy foliage; ideal rock plant. 6 in. $1 / 4$ Oz., $25 \mathrm{c}$.

IIOHOEL (Mornimg Glory)。 (See also ('onvolvuliss). H.A.C Clumbers of rapid growth with beautifu! and varied flowers; for covering walls, trellises, arbors or stumps of trees, they are invaluable. $20 \mathrm{ft}$.

Voctiflor: sranditlora (Moonflower). Large pure white. fragrant flowers which open at evening...........1/4 oz., $30 \mathrm{c}$.

Quanoglit hybria (Cardinal Climber of Cypress vine). Strong, rapid climber, with fern-like foliage, literally covered with cardinal-red flowers which continue till frost

Rubro-caerulea (Heavenly Blue). Large flowers, deep sky-blue...........1/4 oz., 30c.

cietosa (Brazilian Morning-glory). Flowers rose pink, borne freely in large clusters; stems and leaf stalks covered with reddish-brown hairs.

Imperial Japanese hixed $\begin{aligned} & 1 / 40 z ., 25 c . \\ & \text { (Morning- }\end{aligned}$ glory ) ....................................................... 1 oz., $50 \mathrm{c}$.

(See Cypress Vine).

IVV. Wenilworth. H.H.P. Neat trailer for rock gardens. Small snapdragon like flowers. Attractive foliage.

JOALPH' COA' (See Amaranthus)

KoCHI1. tricophylla (Belevedere, Summer Cypress, or Mexican Fire Bush). H.A. Grow in a perfect pyramidal shaped cypress bush, with small feathery light green foliage. Becomes a lovely crimson hue about September. $21 / 2$ ft. .................................................1/4 oz., 25c.

KUIZU VINE. (Pueraria Thunbergiana). H.P. A splendid climber for covering permanent verandas, dead trees, etc. Large green foliage and pea-shaped flowers. ......................................

I.NTANA. Bruants. Dwari Hybrids. Mixed. G.P. One of the most desirable greenhouse or bedding plants; constantly in bloom. $2 \mathrm{ft} . . . . .1 / 4$ oz., $50 \mathrm{c}$.

LATHYRUS latifolius. Perennial Sweet Peas. H.P. Hardy perennial, fine for cutting. $6 \mathrm{ft}$.

White, Pink, Red, or Mixed.....1/4 oz. $35 \mathrm{c}$.

IAPRTUR。 H.A. Elegant and ornamental plants, producing in great variety of form, some of the most beautiful flowers in cultivation.

tall stroch-flowering double. Plants branch freely, bearing long spikes of beautiful double flowers. $21 / 2 \mathrm{ft}$.

Ios Angeles. Rich salmon overlaid with brilliant rose.......................1/8 oz., 35c. La France. Lovely salmon pink. Mixed $1 / 8$ oz., 35c. .15 $1 / 4$ Oz., 35c. .10

\section{IRKSI'UR-Continued}

GIIN IYPERIM. Base branching, ideal for cut flowers with stems from 3 to 4 feet long which branch from the base of the plant.

Bue Apire. Intense deep Oxford Blue. $1 / 8$ Oz., $75 \mathrm{c}$.

.10 Exquisite Pink. Soft pink shaded salmon. ...................................................1/8 oz., $50 \mathrm{c}$. Exumisite Rose. Rose pink... $1 / 8$ oz., $50 \mathrm{c}$. Lilac Spire. Lilac ....................1/8 oz., $75 \mathrm{c}$. Iiss California. Deep pink, shaded salmon .............................................1/8 oz., $75 \mathrm{c}$. Inperial Mixed ...................................1/8 oz., $35 \mathrm{c}$. Pkt.

LEVIOY VERIBEA (See Verbena).

LINIRI cymbalaria (See Kenilworth Ivy).

LINUM. H.A. Free flowering plants for borders.

grandiflura rubrum. Single scarlet flowers. $1 \mathrm{ft}$.............................................1/4 oz., $25 \mathrm{c}$.

15 pereme. H.A. A lovely plant with blue flowers. $1 \frac{1}{2} \mathrm{ft}$...............................1/4 oz., $25 \mathrm{c}$.

LOBELIA. H.H.A. Bushy plants with pendant branches; very profuse flowering. Fine for baskets or edging borders. 6 in.

Barnalod's perpetual. Deep blue with white eye. ......................................1/8 oz., $\$ 1.00$

cardinalis hybrids "Queen Victoria." (Cardinal Flower). Dark-leaved with spikes of brilliant scarlet flowers. Fine border plant

LOVE - HES - IBITEIING (See Amaranthus).

LOVE-IN-A-MIST (See Nigellia).

I.CPINLS. Free flowering plants with long spike flowers. The Annual and Perennial varieties are among the most useful of our garden flowers, either for mixed borders or house decorations. $2 \mathrm{ft}$.

Innual Varieties Hartweigii. White, Blue, Rose or Mixed...................1 oz., $50 \mathrm{c}$.

Perennial Varieties Harkness' New Hyhrils. Mixture of Art Shades.

$1 / 8$ oz., $65 \mathrm{c}$.

Towner"s New Hybrids. Early variety of mixed colors ............................1/8 oz., $65 \mathrm{c}$.

I YCHNI' Irkwrighti. H.P. A hybrid of "Chalcedonica" and "Haageana." Large brilliant flowers. Color from orange; scarlet to soft salmon-pink. $1 / 8$ Oz., $35 \mathrm{c}$.

chalcedonica, (Rose Campion). Fine scarlet cross-like flowers. 18 in. $1 / 4$ oz., $50 \mathrm{c}$.

MARIGOLDS. H.A. The African and French Marigolds are old favorite free-flowering annuals of easy culture; both are extremely effective. The former have uniform large yellow or orange-colored flowers and well adapted for large beds or mixed borders. The latter are dwarfer in growth, with beautiful striped flowers, and are better suited for bedding purposes and pot culture. 
MARIGOLI)S-d'ontinued

Ifrican Varieties. Showy Flowers. $3 \mathrm{ft}$. Orange Ball. Extra double, deep golden orange ........................................1/4 oz., 40c. Lemon (queen. Extra double, soft lemon yellow ....................................1/4 oz., 40c. Delight of the Gardell. (Indian Yellow). Superb light lemon...1/4 oz., 30c. Pride of the Cardell. Dwarf, double quilled gold IIixed $1 / 4$ oz., 30c $1 / 4$ Oz., $25 \mathrm{c}$

Freuch Varieties. Small flowers. $1 \mathrm{ft}$ Gold Striped. Double, golden yellow flowers, each petal striped with rich mahogany-red ....................................1/4 oz., 35c Lilliput. Double, rich brown, narrow thread-like edge of yellow...1/4 oz., 35c Golden Ball. Pure gold yellow, good colde flowers Iixed. Dwarf double ...............1/4 oz., 25c. single Brow Guld Elge Flowers golden yellow marked with velvety brown. Compact bush. 9 in....1/4 oz., $35 \mathrm{c}$.

IARVEL OF PERE. (Four O'Clocks). H.A. A well-known, handsome, free flowering garden favorite; does well everywhere. Mixed. $2 \mathrm{ft} . . . . . . .1$ oz., $25 \mathrm{c}$.

IATRICIRIA capensis fl. p!. (Feverfew). H.H.P. Low growing plants for beds and edgings, dwarf double white. 12 in

IECONOPSIS Baileyi. A beautiful new perennial originally found in Thibet in 1913. It bears an irregular cyme of nodding flowers of a glorious shade of sky-blue, a ring of golden anthers adds to the beauty of the bloom...

IESEYBRY INTHEICI erystallinum. (See Ice Plant).

MICNONETTE, H.A. The popular fresrant garden annual. The seed can be sown at any time, and if successive sowings are made its fragrant, modest colored flowers may be gathered outdoors until November. 12 in.

sweet-scented. (Reseda odorata grandiflora). The large flowering garden variety

Nlan's Defiance. Under favorable conditions its spikes will be from 12 to 15 inches long. Florets are of remarkable size. An etxraordinary keeper. A good winter forcer........................1/4 oz., 35c.

Goliath Red Extra large spikes of brilliant red color, extra fine, true. $1 / 4$ oz., $35 \mathrm{c}$.

MIMOSI pudiea (Sensitive Plant). H.H.A. An interesting plant with rosy-lilac flowers. The leaves close when touched. 12 in. ...........................................1/4 oz., 50 c

MIMTIUS. Showy, half-hardy annuals, with handsome flowers; excellent for pots or garden. 6 in.

tigrinus. Spotted, mixed

moschatus (Muskplant). Fragrant, for pots

1-16 oz., $\$ 1.00$

MTRABILIS (See Marvel of Peru).

MOVORDICA. H.A.C. Trailing plants, with curious foliage and fruit.

balsamina (Balsam-apple). Orange fruit. $1 / 4$ oz., $25 \mathrm{c}$.
Pkt.

OENOTHERI (Evening Primrose). Lamarckiana. H.A. Yellow, useful for sunny position, looming the entire Summer. 12 in............................................................

PINSY. H.H.P. The most popular flower grown. They thrive best in a cool, moist, but well-drained soil. Sow the

charantia (Balsam-pear). Copper cololed scarlet fruit ........................1/4 Oz., 25c.

volvus).

IUSK (See Mimulus)

IYOSOTIS or FORGET-IE-NOTS。H.H.P Fine for borders or cutting... $1 / 4$ oz., $25 \mathrm{c}$. be sown any time from Sprin's until Midsummer. 9 in.

lpestris royal blue. Early and free flowering; color deep indigo blue. Fine for borders or cutting... $1 / 4$ oz., $25 \mathrm{c}$. dwarf, compact growth, with a multitude of bright blue flowers in dense umbels $1 / 4 \quad$ oz., $\$ 1.00$ alustris semperfloreus. The true water Forget-Me-Not. Blooms from early Spring until Autumn. Dark blue.

Ruth Fischer Hybida. Compact growth; blue flowers .................................................. H.A. Tom Thmmb or Dwari Varieties. These have a compact habit and attractive foliage; bloom in two months from sowing, and most profusely the whole season. 12 inches.

Queen of Tom Thumbs. Variegated leaved. Choicest mixed ...........................1 oz.

Colored, Extra Fine Hixed. This self colored sorts (no spotted or speckled) and has the advantage of letting the variety of colors come out more effectively. A very showy mixture...Oz. H.A.C. Tall or Climbing Varieties. Adapted for rockwork, banks, covering trellises or rustic work; the seeds, if picked young, are an excellent substitute for capers. $6 \mathrm{ft}$

Lobl's Qneen. Mixed. Variegated leaved with very distinct and pretty colors,

Cloice Uixture First quality, extra... Oz.

NEMESI. strumosa grandiflora suttoni. H.A. Splendid for bedding or forcing in greenhouse. Mixed colors. Bushy plants; flowers of unique form. $12 \mathrm{in.}$ $1-16$ oz., $\$ 1.00$
Fragrant, starshaped white flowers. $3 \mathrm{ft} . . .1 / 4$ oz., $35 \mathrm{c}$. affinis Hybrids, Large scented flowers, mixed shades ...........................1/4 oz., 40c. tiful border plants. 18 inches.

Miss Jeliyll. A lovely variety with cornflower-blue blossoms; splendid for flower-blue very double, beautiful. 
PAXSY_Continned

seeds in April and May for Summer flowering and August for early flowers the following spring. Our mixtures contain a large variety of colors.

Roggli (iiant. (Swiss Pansy). (New.) Flowers of enormous size and with overlapping petals; many brilliant colors and shades, making a wonderful comination, excellent for greenhouse culture as well.

Lake of Thun. A solid blue pansy with dark blue blotches.....................1/8 oz., $\$ 1.00$ Cardinal shades ............................1/8 oz., $\$ 1.00$ Golden Yellow ..........................1/8 oz., $\$ 100$ Mixed-Rare and effective colors. I/8 oz. $75 c$

Triumph of the Cinnts Yixed, Immense flowers of great brilliancy and richness of colors, including many new and rare shades ..........................1/3 oz 35c

Giant Peter Pan An extremely bright mixture unsuipassed by the range of the riches $\imath$ colors. Flowers round, flat and of good substance.

PAPAVER (See Poppies).

PASSIFIARA caerulea (Passion Flower). H.H.C. Fast growing and free flowering, ornamental perennial climbers, with large showy blue flowers, suitable for conservatory or outside in Summer ..............................................1/4 oz., $40 \mathrm{c}$.

I'ENTS'TEYON gentianoides. Hybrid Gloxinioides. Sensation. New giant flowered. H.P. Highly useful and attractive hardy perennials, and much used in the hardy border. $2 \mathrm{ft} . . . . . . .1 / 8$ oz., $85 \mathrm{c}$.

PETUNIA. H.A. One of our easiest cultivated and freest flowering annuals. Will succeed almost anywhere and give a continuity of the most brilliant bloom from June till killed by frost. 18 inches.

Howard's Star. Bright purple, white star ……….....................................1/8 oz., 45c.

General Dodds. Velvety blood-red. $1 / 8$ oz., $45 \mathrm{c}$

Inimitable. Blotched and striped.

$1 / 8$ oz., 35c.

Nana compacta Alderman. Deep violet. $1 / 8$ oz., $45 \mathrm{c}$.

Yorma. Blue with white star, compact habit, very showy............1/8 oz., $45 \mathrm{c}$. Rosy Iorn. Soft carmine pink. $1 / 8$ Oz., 35c.

Rose of Heaven. Dwarf rose pink. $1 / 8$ oz., $45 \mathrm{c}$.

Senator. Gloxinia purple, white throat ........................................................1/8 oz., $35 \mathrm{c}$. Violacea. Deep violet...............1/8 oz., $45 \mathrm{c}$. Vixed, all Nana Erecta varieties. $1 / 8$ oz., 35c.

Pendula, Balcony Petunia. White, crimson, rose, blue or mixed......1/8 oz., $75 \mathrm{c}$.

Ruffled Giant Fringed Mixed. Large flowers appearing as though artificially ruffled.

Giant Double Fringed Mixed. A strain of Double Fringed Petunia producing
Pkt.

a high percentage of extremely large

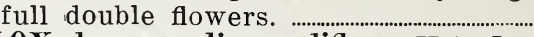

PHLOX drummondi grandiflora. H.A. Improved, large-flowering strain of this famous garden annual. Prefers a light, rich loam in sun or semi-shade. Seed may be sown in the open ground any time after danger from frost is past. 12 in.

White, pink, crimson, yellow, lilac, or mixed $1 / 4$ oz. $35 \mathrm{c}$

stellata splendens. Star-like crimson. $1 / 4$ oz., 35c.

PHYS ILIS francheti (Chinese Lantern). (See Everlasting Flowers).

PINKS (See Dianthus).

POPPIES. Showy, free blooming, oldfashioned flowe: $s$. Very effective in mixed borders.

Single Annual Varieties. 12 in. glaucum (The Scarlet Tulip Poppy).

$1 / 4$ oz., $25 c$

Admiral, pure white edged scarlet.

$1 / 4$ oz., 25c. .10

Flanders Field, bright red... $1 / 4$ oz., $25 \mathrm{c} . \quad .10$

American Legicn Shirley. Brilliant orange-scarlet, yellow anthers. Should be grown extensively for Poppy Day. $1 / 4$ oz., $25 \mathrm{c}$

Doublo Annua! Variéties

Carnation-flowered. Mixed colors. 10 Paeony-flowered. Mixed colors $1 / 4$ oz., $25 \mathrm{c}$. .10

Dazzle1: Brilliant orange scarlet. $1 / 4$ oz., $25 \mathrm{c}$. .10 scarlet. $1 / 4$ oz., $25 \mathrm{c}$.

Iceland Poppies. H.P. White, these are hardy perennials, they flower the first year from seed, blooming almost as quickly as the annual sorts.

Tangerine, Large flowered bright scarlet .................................................1/4 oz., 25c. Sunbeam. Improved strain, robust growth. Colors white, lemon, yel'ow and orange scarlet.......................1/4 oz., 25c.

Oriental Poppies. H.P. Always popul $r$ in any perennial bed. The seed should be sown in early Spring in open ground.

Orientale. "Brilliant." Bright Red. $1 / 4$ Oz., $35 \mathrm{c}$.

Princess Victoria Lonise. Salmon red. (Varies) ...............................................1/4 oz., 35c. Excelsior Mixed ..............................1/4 oz., 25c.

PORTULACA. H.A. One of the freest flowering dwarf annuals, especially adapted for sunny locations. Flowers of the most brilliant colors. 6 in.

double. In splendid mixture, first quality .................................................................1/4 oz., $40 \mathrm{c}$. single. Mixed all colors...............1/4 oz., $25 \mathrm{c}$. .25

PRIMULA sinensis fimbriata (Chinese Primrose). G.P. Double Iixed. 100 seeds
Pkt. .35 
PRIMULA-Continued

Giant Flowered. A grand advance over the Sinensis fimbriata. Flowers very large and solid

- Coral Red, shaded salmon, new and distinct

Excelsior Mixed.

stellata (Star Primula). For cut blooms they are unexcelled and for pot culture they are much more robust in habit and produce many more flowers than the Primula sinensis fimbriata varieties. A choice mixture of eleven varieties .......................................................... Obconica Gigantea. This improved strain of Primula Obconica is much superior to the old type, the flower being much larger and the plants more compact in growth. They bloom profusely during the winter months.

Gchmids Riesen, red

Fassbelider, red. Very dark, most perfect structure

Pearl of Niederrhein, dark red, salmon tinted

Friesdori, rose tinted salmon........................

Malacoides. Piuk Beauty. Rosy pink shading to mauve

Keweusis. Verbena-scented yellow prim-

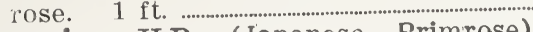

Japcnica. H.P. (Japnese Primrose). vixed colors ...................................................................

Vulgaeis Hybrils. H.P. English yellow Primrose hybrids

Veris (cowslip), mixed ..............................................

1) PWHIRII. H.H.P. Fine for edging and borders. 6 in.

a.ranl (iolden Feather. Bright yellow foliage ....................................................1/4 oz., $50 \mathrm{c}$.

H viridull.. Single mixed............1/4 oz., 35c.

hylyidum. fl. pl. Double. H.P. Large Daisy-like or Cosmos flowers; blooms in early summer and late Fall. 18 in.

KHO1) ITHE (See Everlasting Flowers).

Ric'INUE, Hixel Varieties. (Castor Oil Plant). H.A. From seed they quickly attain gigantic proportions, and are 1y a trost. QOCLE' \$WET (Hesperis) Mixed cors H.P. A very interesting useful free-flowering plant. 18 in. I/4 Oz., $35 \mathrm{c}$.

RUIBE(KIL Newmanni. H.P. (Black eye-Susan). Bright orange with black cone. $2 \mathrm{ft}$.........................................1/4 oz., 50c.

Echinacea. (Red perennial Sunflower).

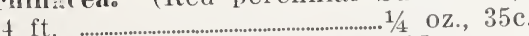

SILPIGuossis variabilis grandiflora superhissama. New Emperor. H.A. One of the prettiest annuals of easy culture; funnel-shaped flowers. Facing upward revealing marking of veins running through the groundwork of the flower. Orchid-like flowers. $2 \mathrm{ft}$. $1 / 4$ oz., $35 \mathrm{c}$.

SALVIA (Flowering Sage). H.A. One of our most handsome Summer and Autumn flowering plants, growing in- to compact bushes 2 to $3 \mathrm{ft}$. high and literally ablaze with brilliant flowers. splendens. Glory of stuttgart. Tall, scar-

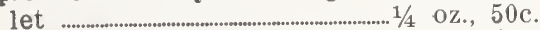
compacta America or Globe of Fire. The earliest freest and most continuous bloomer ......................................1/8 oz., $50 \mathrm{c}$.

PRLIUS. Extra early flowering. Blooms about four weeks earlier than the earliest varieties. Dwarf compact grower. Blooms freely, bright vermillion scarlet

Farinacea. H.P. Grown also as an annual, light blue flowers, long spikes, makes a good blue line. $2 \frac{1}{2} \mathrm{ft}$. $1 / 4$ oz., $35 \mathrm{c}$

SIPOXIRIA (Bounciug Bet). Ocymoides. H.P. Very showy rock plant, producing masses of small bright rose flowers during the Summer months. 9 inches ...................................................1/4 oz., 25c.

SCIIIOSA or HOURNIYG BRIIE. H.A. One of our best Summer flowering annuals. The rich and beautiful colored flcwers are very handsome and excellent for cutting; profuse bloomer. June to October. $21 / 2 \mathrm{ft}$.

Large-flowering Tall Double Varieties. Izure Fairy, rich, soft blue $1 / 4$ oz., 25c. .10 Cherry Red .....................................1/4 oz., 25c Black Prince, deep purple black. $1 / 4$ oz., $25 \mathrm{c}$

Peach Blossonn. A beautiful shade of peach blossom pink, of large size and long stems, an excellent cut flower.

Shasta, pure white ....................1/4 oz., 25c. .10 sulplinr Yellow ...............................1/4 oz., 25c. .18 Finest llixed ..........................................1/4 oz., 25c. .10

Caucasica-House's New Hybrids. Edges rufiled and fringed, light lavender colors to dark blue.....................1/8 oz. $60 \mathrm{c}$

S(HIZINTHCS. (Butterfly flower.) Hybridus grandiflorus. H.H.A. Beautiful and showy, erect growing, hardy annuals for house or garden; very flowering, continuing through the Summer and Autumn. 1/1/2 ft., mixed color's …….............................................1/4. oz.. 35c

SENSITIYE PLINT (See Mimosa pudica)

SNAPHRAGON (See Antirrhinum).

STITICE (See EVERIISTING FLOW. ERS)。

STEVII Serrata. Numerous pure white fragrant flowers. Very useful and popular for winter cutting

STOKESIA cyanea. (Cornflower aster). H.P. Lavender blue flowers. $2 \mathrm{ft}$ $1 / 4$ oz., $35 \mathrm{c}$

STOCKS, Early Giant Imperial. A splendid addition to the early forcing class; of tall branching habit, from 24 to 30 


\section{S'TOCK'S-Continued}

inches high and producing a very high percentage of double flowers. Mixed colors $. .1 / 8$ oz., $35 \mathrm{c}$

SUNFLOWER. H.A. Single Russian. Well-known hardy annuals, the small flowering sorts being very useful for cutting, while the larger sorts are very ornamental and useful, blooming all Summer. Enormous flowers. 6

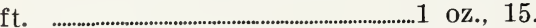

SWEET PEAS. H.A. As soon as the ground can be worked in Spring sow the seed in trenches at least 6 inches in depth, then as the plants grow fill in the soil about an inch ar a time until the trenches are full, taking care not to cover the plants Apply liquid manure occasionally. Do not allow the flowers to form seed.

Asta Ohn, soft mauve.

Countess Spencer。 Light blush pink picotee edge.

Flamingo. Orange scarlet cerise.

King White. Largest flowered white.

Mary Pickford. Cream pink.

Tangerine Improved. Glowing orange.

Dobbie's Cream.

Scarlet Fmperor.

Warrior. Maroon.

All the above named varieties, 1 oz., $35 \mathrm{c}$.

Spenser Mixed

1 oz., $25 \mathrm{c}$.

Eckford Mixed

1 oz., 15c. .05

SWEET SULTAN (See Centaurea).

SWEET ROCKET (See Rocket).

SWEET WILLIMI (Dianthus barbatus). H.B. Showy, of easy culture; splendid for beds and borders with their rich varied flowers.

Double-flowering, mixed ............1/4 oz., $25 \mathrm{c}$.

Diadem. A deep rich crimson with white eye .............................................................1/4 oz., $25 \mathrm{c}$.

Newport Pink. Salmon rose-pink flowers, borne on long stems......1/4 oz., 35c.

Scarlet Beauty. Intensely rich deep scarlet ................................................................1/4 oz., 35c.

Holborn Glory. auricula-eyed... $1 / 4$ oz., $25 \mathrm{c}$.

Single Annual. Mixed flower of good size, will bloom the first year. $1 / 4$ oz., $25 \mathrm{c}$.

Namus compactus fl. pl. Extra double dwarf mixed ....................................1/4 oz., 25c.

THUNBERGIA. Finest Mixed. H.A.C. Beautiful, rapid growing climbers. $5 \mathrm{ft}$.

TRITOMA. Express Early Hybrids. H.H.P. A new perpetual flowering race. The colors embrace yellows and salmons to deep crimsons...

VIIERIAN. (Garden Heliotrope). H.P. Vixed colors, border plant, fragrant iners, odor resembling that of the heliotrope. $2 \frac{1}{2} \mathrm{ft}$. .....................1/4 oz., $30 \mathrm{c}$.

VERBENA. H.A. The Verbena is a universal garden favorite, very few plants

\section{Pkt. VERBENA-Continued}

making a more gorgeous display of brilliant flowers from Spring till late in the Autumn. 12 in.

\section{Hybrida Yammoth.}

Etna, large trusses of intense geranium red

Lucifer, vivid scarlet

Luminosa, pink shaded to salmon........... Dark Purple Mixed

Lemon (Aloysia citricdora). Lemon scented leaves

Pkt.

VERONICA (Speedwell). H.P. Spicata. Mixed colors, a good rock garden plant. $1 \frac{1}{2}$ ft. ................................1/2 oz., $50 \mathrm{c}$.

VINCA. H.H.P. Splendid plants for bedding and edging; glossy dark green foliage and pretty pink and white flowers. 2 ft. Mixed colors... $1 / 4$ oz., $60 \mathrm{c}$.

VIOLA. (Tufted Pansies). Jersey Gem. H.H.P. The flowers are a pleasing

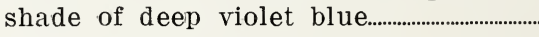

VIOLET. Viola odorata. H.P. Sweet-

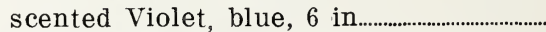

WALLFLOWER, Early Wonder. H.A. If sown in heat during March these will flower during the Summer and Autumn. Excellent for forcing................1/4 oz., $\$ 1.00$

WUD CUCUMBER (See Echinocystis).

XERANTHEMUM (See Everlasting Flowers).

ZINNIAS (Youth and Old Age). H.A. These well-known garden favorites are one of the most brilliant Summerflowering plants. The flowers are large, very handsome, and borne in great profusion. They succeed best in a sunny situation. $2 \mathrm{ft}$.

Double Dahlia-Flowered. This type, the latest development in Zinnias, bears flowers of mammoth size and in form like a decorative Dahlia.

Exquisite, light rose.

Golden State, rich orange yellow.

Scarlet Flame, bright scarlet orange blend.

Orole, orange and gold bicolor.

Dream, deep lavender to mallow purple.

Canary Bird, delicate shade of primrose.

Mixed.

Any of the above varieties...1/8 oz., $35 \mathrm{c}$.

Giant Mammoth or California Giants. The great advantage of this type is that the very large flowers are of enormous size, are flat and graceful. Cerise Queen, cerise rose.

Enchantress, light rose.

Lemon Queen, lemon orange.

Miss Wilmott, soft pink.

Orange King, cadimium orange.

Rose Queen, bright rose.

.10 Scarlet Queen, glowing scarlet.

Mixed.

Any of the above varieties...1/8 oz., 35c. .20 


\section{FLOWER SEEDS FOR DIFFERENT PURPOSES AND SITUATIONS}

For deseription and prices, seo general list.

\section{CLIMBING VINES}

$\begin{array}{ll}\text { Ballooll Vine } & \text { Cypress Vine } \\ \text { Canary Bird Vine } & \text { Dolichos } \\ \text { Cobaca } & \text { Echinocystis } \\ \text { Convolvulus } & \text { Gourds }\end{array}$

$\begin{array}{ll}\text { Humulus } & \text { Kudzu Vine } \\ \text { Ipomoea } & \text { Lophospermum } \\ \text { Lathvrus } & \text { Mina Tobata } \\ \text { Kenilworth Ivy } & \text { Maurandia. }\end{array}$

Nomordica

Nasturtium

Passiflora

Sweet Peas
Thunbergia

Verhena, Lemo
Violet

Trallflower

Alyssum
Asperula
Carnations
Cleome

FRAGRANT FLOWERS FROM SEEDS

$\begin{array}{llll}\text { Dianthus } & \text { Mathiola } & \text { Nicotiana affinis } & \text { Sweet Pea } \\ \text { (Hardy) } & \text { Mignonette } & \text { Polyanthus } & \text { Sweet Rocket } \\ \text { Heliotrope } & \text { Mimulus } & \text { Scabiosa } & \text { Sweet Sultan } \\ \text { Lavender } & \text { moschatus } & \text { Stock } & \text { Sweet William }\end{array}$

\section{PLANTS}

Bellis
Candytuft
Centaurea
Lobella

\section{AD}

\section{FOR}

Ageratum

Alyssum

Armeria

Begonia

Marigold
Myosotis
Nasturtium
Nemesia

\author{
Nigella \\ Pennisetum \\ setunia \\ Phlox, Dwarf
}

Portulaca
Pyrethrum
Sweet William
Sweet Pea, Cupid

Tagetes

Viola

Zinnia Lilliput

GREENHOUSE AND POT PLANTS FROM SEEDS

Abutilon

Acacia.

Antirrhinum

Angelonia

Aralia

Asparagus

Begonias
Calceolaria
Celosia
Celsia
Chrysanthemum
Cineraria

clerodendron

Clianthu=

Coleus

Cyclamen

Dracaena

Geranium

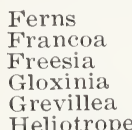

Ferns
Francoa
Freesia
Gloxinia
Grevillea
Heliotrope

Impatiens

lantana

Primula

Shamrock

Smilax

Stevia

Streptocarpus

Sweet Peas

Trachelium

Verbena

EVERLASTING FLOWERS FOR WINTER DECORATIONS

Acroclinium Globe Amaranth Honesty, Lunaria Rhodanthe Helichrysum

Statice

Xeranthemum

Edelweiss

\begin{tabular}{|c|c|c|c|c|}
\hline $\begin{array}{l}\text { Amaranthus } \\
\text { Cineraria }\end{array}$ & $\begin{array}{l}\text { Centaurea } \\
\text { candidissima }\end{array}$ & $\begin{array}{l}\text { Centaurea } \\
\text { gymnocarpa }\end{array}$ & $\begin{array}{l}\text { Coleus } \\
\text { Corn, Rainbow }\end{array}$ & $\begin{array}{l}\text { Euphorbia } \\
\text { Kochia } \\
\text { Perilla }\end{array}$ \\
\hline
\end{tabular}

PLANTS FROM SEEDS SUCCEEDING IN PARTIALLY SHADED PLACES

$\begin{array}{llllll}\text { Anemone } & \text { Begonia, } & \text { Coreopsis } & \text { Digitalis } & \text { Mimulus } & \text { Polyanthus } \\ \text { Antirrhinum } & \text { Tuberous } & \text { (Hardy) } & \text { Ferns } & \text { Myosotis } & \text { Poppies (Hardy) } \\ \text { Aquilegia } & \text { Bellis } & \text { Cowslip } & \text { Hardy Primrose } & \text { Oenothera } & \text { Schizanthus } \\ \text { Auricula } & \text { Canterbury Bells } & \text { Delphinium } & \text { Linum } & \text { Pansy } & \text { Violet }\end{array}$

$\begin{array}{ll}\text { Bellis } & \text { Cowslip } \\ \text { Canterbury Bells } & \text { Delphinium }\end{array}$

Linum

Violet

ANNUAL FLOWERS FROM SEED, SUITABLE FOR CUTTING

Agrostemma
Antirrhinum
Arctotis
Asters
Calendula
Calliopsis
Candytuft

\section{Carnation} Celosia plumosa Centaurea Chrysanthemums Clarkia Cosmos Dahlias
Dianthus

Didiscus

Dimorphotheca

Eschscholtzia

Gaillardia

Godetia

Gypsophila
Hunnemannia Phlox

Larkspur

Lavatera

Lupinus

Marigolds

Vignonette

Nigella

$\begin{array}{ll}\text { Phlox } & \text { Sweet Peas } \\ \text { Poppies } & \text { Sweet William } \\ \text { Salpiglossis } & \text { Verbena } \\ \text { Scabioš̈ } & \text { Walliower } \\ \text { Statice } & \text { Zimnias } \\ \text { Stocks, Ten Week } & \\ \text { Sunflower } & \end{array}$

\section{HARDY PERENNIALS WHICH}

Achillea
Aconitum
Adonis
Agrostemma
Alstroemeria
Alyssum
Anchusa
Anemone
Anthemis
Aquilegia
Arabis
Esperula
Aster
Aubrietia
Auric'sa

$\begin{array}{ll}\text { Bellis } & \text { Digitalis } \\ \text { Bocconia } & \text { Echinops } \\ \text { Boltonia } & \text { Edelweiss } \\ \text { Callirhoe } & \text { Eremurus } \\ \text { Campanula } & \text { Erigeron } \\ \text { Candytuft } & \text { Erysimum } \\ \text { Centaurea } & \text { Erilus } \\ \text { Cerastium } & \text { Eupatorium } \\ \text { Chelone } & \text { Gaillardia } \\ \text { Chrysanthemum } & \text { Galega } \\ \text { Coreopsis } & \text { Gaura } \\ \text { Cowslip } & \text { Geum } \\ \text { Delphinium } & \text { Grasses } \\ \text { Dictamnus } & \text { Gypsophilia } \\ \text { Dianthus } & \text { Helenium }\end{array}$

Helianthus
Heuchera
Hibiscus
Hollyhocks
Incarvillea
Lathyrus
Linaria
Linum
Lobella
Lupinus
Lychnis
Matricaria
Nierembergia
Pansies
Pentstemon

Phlox
Physalis
Physostegia
Platycodon
Polemonium
Polyanthus
Poppies
Potentilla
Primula
Pyrethrum
Rehmannia
Rocket
Romneya
Rudbeckia
Salvia

Scabiosa

Silene

Statice

Stokesia

Sweet IVilliam

Trachelium

Tritoma

Trollius

Valeriana

Verbena

Verbascum

Veronica

Viola

Violet

Description and prices of any of the above seeds will be found on pages 30-40. 


\section{AMARYLLIS}

They should be grown in rich, sandy loam, with good drainage, and require abundant moisture when growing; but at their season of rest water should be given sparinglf.

Hippeastrum, New Hybrids. The finest race of

Amaryllis in cultivation. Each, $\$ 1.00$; doz., $\$ 10.00$.

\section{BEGONIAS}

Splendid pot plants for the house or greenhouse, and especially valuable for beddins, flowering in the greatest profusion throughout the Summer. For bedding they should be started in hotbed in March and April.

\section{SINGLE TUBEROUS-ROOTED}

Separate Colors: Crimson, Pink, Salmon, White Yellow or Vixed. Each, 35c; doz., $\$ 3.50 ; 100$ $\$ 25.00$.

\section{I)OUBLE TUBEROUS-ROOTED}

Separate Colors: Crimson, Pink, Salmon, White

Yellow or Mixed. Each, $35 \mathrm{c}$; doz., $\$ 3.50 ; 100$, $\$ 25.00$.

\section{BOUSSINGAULTIA BASELLOIDES}

(Madeira, or Mignonette Vine)

An old-fashioned popular vine, covering a larze space in a short time. Fleshy heartshaped leaves of a light green, and numerous racemes of feathery white flowers of delicious fragrance. Protect with litter in this latitude. Strong tubers, $15 \mathrm{c}$ each; $\$ 1.50$ per doz.

\section{CALADIUM ESCULENTUII}

\section{(Elephant's Ear')}

Among the most effective plants in cultivation for beds, borders, or for planting out upon the lawn; they are used extensively in many of the public parks where their decorative value is greatly appreciated. To obtain the best results they should be planted where they will obtain plenty of water and an abundance of rich compost. When full size they stand six to ten feet high, and bear immense light green leaves three to four feet long by two and a half wide.

Large Bulbs

Each

First Size Bulbs

.30

Second Size Bullos

\section{FANCY-LEAVED CALADIUMS}

Few, if any, of the Summer foliage plants equal the Fancy-leaved Caladiums in their rich and gorgeous, yet soft, coloring. All the varieties are of marvelous beauty for the furnishing of the conservatory durms rne Summer months, or even for outdoor bedding in shady or semi-shady positions. Bulbs do best if started in pots, planting one bulb to a 6-inch pot. Bulbs should be planted and handled similar to suggested indoor culture of tuberoses and begonias.

Fancy-leaved Mixed Varieties. Each, $40 \mathrm{c}$; doz. $\$ 4.00 ; 100, \$ 30.00$.

\section{CANNAS}

Cannas should not be planted until the warm weather sets in, or about May 15th. If planted too early the bulbs are apt to rot.
The following are a selection of the largest flowering varieties which we can recommend for bedding or borders. We shall be pleased to supply other varieties not named at catalog prices.

Doz. $\quad 100$

Fiery Cross. Very large, vivid scarlet. Foliage green. $5 \mathrm{ft}$.......

Hungaria. The ideal pink bedder; large trusses of flowers. $3 \mathrm{ft}$.

$\$ 1.50 \quad \$ 9.00$

$1.50 \quad 10.00$

King Humbert. Bronze foliage, with orange-scarlet flowers. $4 \mathrm{ft}$.

Panama. An attractive rich orange-red, with edge of golden yellow. $3 \mathrm{ft}$.

$1.50 \quad 10.0 €$

The President. A gorgeous green leaf variety with zreat trusses cf orange-red flowers

Yellow King Humbert. A beautiful yellow, lightly spotted red, with green foliage. $5 \mathrm{ft}$...................

Mixed Varieties

\section{$1.50 \quad 9.00$}

$1.50 \quad 9.0 €$

$1.50100 \mathrm{C}$ 1.208 .0 个

\section{DAHLIAS \\ See page 44}

DIELYTRA

(Dicentra spectabilis)

(Bleeding Heart or Seal Flower)

An old-fashioned favorite; its long racemer of graceful heart-shaped pink flowers are al. ways attractive. It is used largely for forcing but is also excellent for the garden border and especially valuable for planting in the shade. Strong clumps, 75c. each; $\$ 7.50 \mathrm{pe}$ doz.; $\$ 60.00$ per 100 .

\section{GLADIOLUS \\ See page 45 \\ GLOXINIAS}

A gorgeous plant either for the conservatory or garden. They prefer a moist soil and a shady situation. Bulbs may be started as early as January, but should not be set outdoors until after May 15th. We offer extra fine large bulbs.

Ii wanted by Parcel Post, add 10c per doz: 20c per 100 .

\begin{tabular}{|c|c|c|c|}
\hline & Each & Doz. & 100 \\
\hline . & .50 & 4.50 & \\
\hline & .5 & 4.50 & \\
\hline oice Mixed Colo & .50 & 4.50 & \\
\hline
\end{tabular}

\section{IRIS, JAPANESE}

The Japan Iris is perfectly hardy and flowers in great profusion in July and August.

The large size of the flowers is noteworthy as they often reach 6 to 8 inches across in most fascinating combinations.

Gold Bound. Large, pure white, yellow center Helen von Siebold. Reddish violet, veined white, three petals.

Oriole. Large double flowers of rich plum red shaded deep purple.

Pyramid. Violet-blue, veined white in center of each petal.

Templeton. Double light blue, mottled rose and white. 
lictor. White, veined violet-blue, purple center.

Prices of the above, strong clumps, 3 for $\$ 2.00$; doz., $\$ 7.00$.

\section{IRIS, SIBERIAN}

Narrow, glossy foliage, delicate flowers on tall stems. Excellent for cutting as the blooms keep well in water and can be used with other flowers.

Sil)irice orientalis Purplish blue. 2 to $3 \mathrm{ft}$ 3 for $\$ 1.50 ; 10, \$ 4.00$.

Sibivica Perrys Iblue. A large flower of clear blue with horizontal falls. $4 \mathrm{ft}$. 3 for $\$ 2.50$; $10, \$ 7.00$.

Snow Queal. Flowers pure white. A stron growing variety. 3 for $\$ 1.50 ; 10, \$ 4.00$.

\section{IRIS, GERMANICA}

Ambassadewr. S. smoky velvet maroon. F. velvety purple; yellow bearded. One of the finest. Height, 48 inches. Each, $\$ 1.00$.

Caprice, S. rosy red. F. deeper rosy red. Height, 24 inches. Each, 30c.; doz., \$3.00.

Lent 1. Hiliamson. Considered by many the finest variety ever raised in America. $\mathrm{S}$ erect lavende $i$ violet, blended with yellow to ward base. F. rich royal purple, yellow beard. Height, 42 inches. Each, 50c; doz., $\$ 4.50$.

La Neige. Creamy white self with flaring fall petals. Height, 24 inches. Each, 35c; doz. $\$ 3.50$.

I.ort of June. S. lavender blue. F. rich violet blue. Huge flower. Height, 40 inches. Each $\$ 1.00 ;$ doz., $\$ 10.00$.

Lohengrin. A large beautiful pink silvery mauve flower. Each, 30c; doz., \$3.00.

Monsignor. Tall, large blossoms. S. bluish lavender. F. violet with white markings at throat. Flowers immense size. Blooms for a long time. Each, 30c; doz., $\$ 3.00$.

Mother of Pearl. S. light lavender blue with creamy undertone. F. slightly deeper lavende:. Flowers of perfect form on well hranched stems. Exch, 50c; doz., $\$ 5.00$.

Pro :per Tangier. S. light bronze red. F. vel vety ruby purple. White beard with yellow tip. Height, 36 inches. Each, 30c; doz., $\$ 3.00$

l'rospero, S. pale lavender flushed yellow at base. F. deep red purple with light shading at edges. Height, 48 inches. Each, $\$ 1.00$. doz., $\$ 10.00$.

Sherwin-Wright. Clear golden yellow self. Free from any markings. Each, 30c; doz., $\$ 3.00$.

German Iris Mixed. A splendid collection of mixed varieties. Doz., $\$ 2.00 ; 100, \$ 12.00$.

\section{LILIUM}

(Summer Flowering Lilies)

All herbaceous borders should have a few Lilies scattered through them. The sorts offered below can be planted with excellent results during the early spring months. It is in the hardy border that Lilies do best, as they get the benefit of the shade of the surrounding plants, which is so necessary for their welfare; other varieties should be planted in the autumn, and are offered in our autumn catalog

Auratum (Golden-banded Japan Lily). Undoubtedly one of the finest. Its large, graceful, fragrant flowers are composed of six petals of a delicate ivory-white color, thick ly studded with chocolate-crimson spots, and striped through the centre a golden-yellow 3 to $5 \mathrm{ft}$. July, September. Extra large-flow ering bulbs. Each, 40c; doz., $\$ 4.00 ; 100$, $\$ 30.00$.

Henryi. This beautiful and rare variety has bees casled the "Yellow Specicsum," the flowers being a rich apricot yellow with a few brown spots. Grows 3 to $5 \mathrm{ft}$. high, is perfectly hardy and invariably does well. Au gust and September. Extra large bulbs, each $50 \mathrm{c} ;$ doz., $\$ 5.00 ; 100, \$ 35.00$.

Regale (Myriophyllum). his new variety from Western China is admittedly one of the mos beautiful garden Lilies yet introduced. I grows 3 to $5 \mathrm{ft}$. high and blooms out of doors in July. It is perfectly hardy, and flourishes under very varied conditions, the large trum pet shaped, delicately scented flowers, whicl are produced freely, are ivory-white, shaded pink, tinged with canary yellow at the bas. of the petals. Strong flowering bulbs, each $35 \mathrm{c}$; doz., $\$ 3.50 ; 100, \$ 25.00$.

Speciosum Magnificum. Magnificent large flow ers ivory white, suffused rosy-crimson. August and September. Extra large flowering bulbs. Each, 40c; doz., \$4.00; 100, $\$ 30.00$.

Speciosum Rubrum or Roseum. A very popu lar variety. Rosy-white heavily spotted with rich crimson spots. August and September Extra large flowering bulbs, each, $40 \mathrm{c}$; doz $\$ 4.00 ; 100, \$ 30.00$.

Superbum swamp or American Turk's-cap Lily). A beautiful native variety, bright reddish-orange spotted; 3 to $6 \mathrm{ft}$; August Each, $25 \mathrm{c}$; doz., $\$ 2.50 ; 100, \$ 18.00$.

Tigrinum Splendens (Improved Tiger Lily) Bright orange-red, spotted with black; ver: showy; 4 to $5 \mathrm{ft}$; Summer. Each, 25c; doz. $\$ 2.50 ; 100, \$ 18.00$.

\section{TUBEROSES}

One of the most fragrant and popular of the Summer flowering bulbs. May be started in hotbeds or pots, or planted in open ground after first day of May.

Double Pearl. Extra fine bulbs

Single. The single everblooming Tuberose

Each Doz. 100

$\$ 0.15 \$ 1.25 \$ 8.00$

$\begin{array}{lll}.15 & 1.25 \quad 8.00\end{array}$




\section{DAHLIAS "The Glory of Autumn"}

There is little question why the Dahlia has gained in popularity. Largely because of its easy culture, its wealth of color, and its diversified form, it is one of the most popular green plants we have today.

You should look upon them as triumphs of the breeder's art, when you realize that the modern varieties have been evolved from several wild species, growing in high altitudes in Mexico. It has been known to horticulture for upwards of one hundred fifty years, and today we find over 8,000 names of recognized varieties.

The collection below offers a variety of beautiful colors and types with strong stems, extending over a long blooming period-robust, reliable; repaying a small amount of care with a wealth of bloom at a season when the rest of the garden is almost without color.

Sunset Glow. S. C. 6 x 3, Bush 41/2 it. Yellow at base of petals, suffused scarlet and tipped yellow.

Mrs. I. De Ver Warner, Bloom $10 \times 3$, Bush 6 ft. No dahlia planting should be without this universal favorite. Color, a clear, bright lilac rose. The plant is a strong open grower, and the giant flowers can be produced on stem up to 5 feet in length by piuning and disbudding.

Sagamore, e g e, Bloom 7 x 31/2, Bush 5̃ $1 / 2$ it. This dahlia is a wonderful commercial and exhibition variety. Color, amber gold. elusively shaded with a warm salmon rose and orange buff. An open, strong grower with good stems, of uniform large size.

Earle Williams, c g e, Bloom 8 × 4, Bush 51/2 fi. One of the best bi-colored dahlias. A pleasing scarlet distinctly tipped white with an occasional bloom solid red. Flowers deep and large with full centres of regular form on erect stems.

Jane Cowl, Bloom 10 x 6, Bush 51/2 ft. Color, a warm buff and old gold, blending to apricot and rose at the centre. Bush growth is ideal with strong stems holding the giant flowers upright.
Pride of California, Bloom $6 \times 3 \frac{1}{2}$, Bush $5 \frac{1}{2}$ it. A large crimson red shading darker at the center, which is very full; petals notched. Profuse bloomer on good stems.

Iae Grefe, Bloom 7 x 3 S. C. Blush pink tinted cream; of good form, an upright grower, splendid stems, a summer bloomer.

Jersey's Beauty, Bloom 6 x 4, Bush 61/2 ft. Probably the most popular of any dahlia especially as a cut flower. The ideal pink for exhibition. Large, deep flowers of perfect form on long stems. Free, early bloomer with exceptional keeping qualities.

Jersey's Beacon, Bloom $9 \times 4$, Bush $4 \frac{1}{2}$ ft. The most spectacular of the Jersey family. Color, bright scarlet with a buff reflex, giving a two-tone effect. A free, early bloomer of extremely massive proportions with sturdy stems.

Attraction, Bloom $7 \times$ 3, Bush 5 it. Elegant flower of a clear lilac rose, borne on long stiff stems and a Dahlia of exceptional merit.

\section{0c Each-3 for $\$ 1.00$}

\section{HIGH SPOTS OF CULTURE}

Do not plant Dahlias in the shade.

Do not plant them too close to trees, shrubs or buildings.

Do not plant them too early-mid-May is best in the North.

Do not allow more than one shoot to grow from the tuber.

Do not allow more than one flower on each stem.
Do not use nitrogen fertilizers.

Do not pull the clumps-DIG them.

Do not allow tubers to dry out in storage.

\section{AND}

Cultivate, water, fertilize, disbud, and consequently gather the gorgeous blooms in payment for this little care. 


\section{GLADIOLI}

For charm and color few other flowers com zare with Gladoii, their adaptability to garden decoration or to use as cut flowers during the summer and early autumn is surpassed by no other flower. They thrive in almost any good garden soil but better results may be had if the soil is well prepared and enriched with pulverized sheep manure. The tall green stems fairly burst with color and provide a luxuriance of rainbow beauty. If cut as soon as the first one or two flowers are open they will last for ten days in the house, provided the raded flowers are removed and a little of the stem is cut and the water changed daily. Plant bulbs 4 inches deep and 4 inches apart, cultivate frequently and water freely.

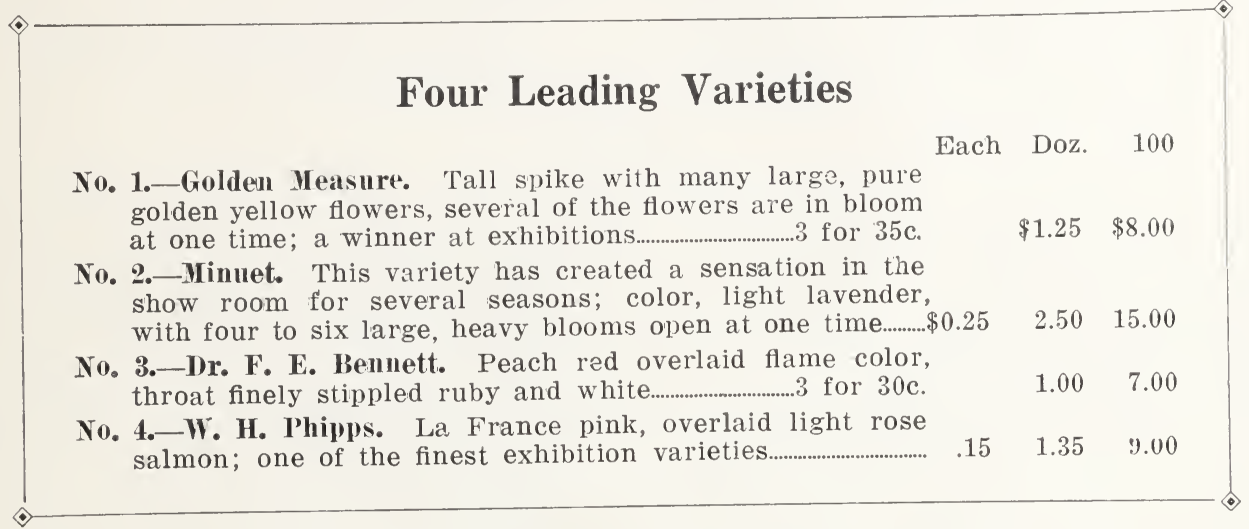

\section{Standard Varieties}

The list of Gladioli offered below comprises our choice of all those in the field after studying and comparing the merits of hundreds of varieties, consideration being given to healthy growth, size and form, coloring, substance of flowers perfectly faced on strong, straight, upright stems. We therefore believe this selection of up-to-date named gladioli is the best of recent introduction as well as the most popular standard varieties.

Irs. Frank Pendleton. The flowers are of largest size, borne on strong straight spikes. In color a lovely salmon-pink with brilliant deep red blotches in the throat.

Yrs. Francis King. Brilliant flamingo-pink, blazed with vermilion-red. Popular variety on account of its attractive color. Splendid for mass effects. Flowers are large in size, well placed on strong, tall spikes.

Crimson Glow. One of the best scarlet varieties, throat overlaid with a velvety scarlet blotch.

L. Yarechal Focl.. A beautiful delicate pink the finest variety of its color in existence.

scarlano. Scarlet blotched ox-blood red in throat; beautifully ruffled; a fine acquisition

Herada. Blooms of immense size on tall straight spikes; color, pure mauve shading to pink in throat.

Mi. Keur. Peach blossom pink, yellow blotch in throat, large flowers.

Irs. Watt. Rich velvet red, six to eight flowers open at one time.

Mrs. Ir. Norton. Very large flowers well set on a tall and graceful spike with 4 to 8 flowers in bloom at one time. Color, white, with edges of petals suffused with soft La France pink; all grower; splendid cut flower variety.

Irs. F. C. Peters. A beautiful shade of roselilac with soft crimson blotch. Very large flowers on long stems.

Evelyu Kirtland. The flowers, of strong substance, are a beautiful shade of rosy pink, darker at the edges, fading to shell-pink a the center with brilliant scarlet blotches on the lower petals.

Flora. A clear golden yellow variety; a strong grower with large spikes of flowers of im mense size; a splendid cut flower variety.

Byron L。 Smith. Lavender pink on white ground. This variety is often referred to as the "Orchid Colored Glad." It grows with good form and the stems are rather slender which adds to its grace.

Irs, Ieon Iouglas. Begonia-rose, striped with flame-scarlet, lower petal pale lemon, speckled ruby. Tremendously large flowers, many open at a time. Very tall, strong stem with several side-shoots, the whole forming a gigantic bouquet.

Muriel. Beautiful pure lilac-blue, with deeper blotch in flame-scarlet throat on lower petals. Many perfectly placed flowers open combination at a time on tall, erect stems. A rare beauty. $20 \mathrm{c}$ each.

Los Ingeles. Delicate salmon-pink with bright cerise markings in the throat, a strong vig orous grower. 


\section{ROSES}

\section{Four Recent Introductions}

Merrouw G. A. Van Rossem-Buds dark orange or apricot, with background of golden yellow, and retain a most marvelous hue of golden salmon and light orange upon opening; reverse of petals generally deep bronze.

Lady Margaret Stewart-A large exhibition bloom with enormous petals. It is of perfect form, with a hish-pointed center grolden yellow, shaded and streaked with orange and red.
President Herbert Hoover-Large flow. ers of a very charming combination of cerise-pink, flame, scarlet, and yellow with broad, thick petals; very fragrant

Talisuan-Brilliant red and gold buds opening to well-shaped blooms of scarlet-orange and rich yellow. Constantly in bloom.

75c Each

Amelis De Greiff-Light Shell and Salmor Pink

Betty-Pale Bluff Pink.

Columbia-Clear Rose Pink

Cleveland-Old Rose Coppery Pink

Criuson Qneen-Velvet Red

Ducliess of Wellington-Saffron Yellow

Etoile de Tronce-Crimson Red

E. H. P. Kingma-Deep Apricot and Orange Yellow

Frauk W. Ioulop-Bright Carmine Rose Pink

Francis Scott Key-Deep even Red Florence Pemberton-Peach Pink

George C. Waud-Orange Red Vermillion

General McIrthur-Brilliant Crimson Red

Gruss \& Teplitz-Deep Crimson Red

Gorgeous-Deep Orange Yellow

Jonkheer J. I. Mock-Carmine Rose-Silvery White

K. A. Victoria-Lemon White

Konigen Carola-Soft Silvery Pink

Killarney Pink-Scarlet Pink

Lady Alice Stanley-Carol Pale Flesh Pink

Lady Ashtowu-Pale Carmine Pink

Lady Pirrie-Coppery Reddish Salmon Yellow

Laurens Carle-Brilliant Velvet Carmine Red

Los Angeles-Luminous Flame Yellow Pink

Louise C. Breslau-Coral Red with Chrome Yellow

La France-Bright Pink

Lady Ursula-Silvery Pink

Marie Adelaide-Copper Yellow
Uis Lolita Armour-Chrome Yellow Shading to Orange

Miss Cyuthia Ford-Brilliant Rose Pink

Iadam Rordeau Job-Canary Yellow

Madam Butterf!y-Yellow Pinl

Mary C of Illchester-Deep Rose Pink

Yadam Leon Pain-Silvery Flesh Pink

Irs. Ambrose Ricarde-Light Yellow Suf. fused in Pink

Madanı E. Herriot-Coral Red Shaded with Yellow

Iadam Jules Bouche-Pearly White

Madam Segond Weber-Rosy Salmon Pink

Marquis de Gannay-Bright Silvery Pink

Mrs. Aaron Ward-Indian Yellow

Irs. A. R. Waddell-Apricot Yellow with Orange

Mrs. George Shawyer-Clear Rose Pink

Ophelia-Salmon Pink and Yellow

Pharisaer-Rosy White

Pax Labor-Li?rht Yellow, Very Double

Prince de Bulgarie-Silvery Flesh and Saffron Yellow

Queen of Fragrance-Shell Pink Tipped with Silver

Radiance-Light Silvery Flesh Pink

Red Radiance-Deep Rose Pink

Rose Varie-Clear Rose Pink

Sor de Claudis Pernet-Sunflower Yellow

Sor de Pres Carnot-Rosy Flesh Shaded White

William F. Dreer-Shell Pink with Yellow Willowmere-Carmine and Rich Salmon Pink Wm。 R Smith-Blush White Pink

\section{HYBRID PERPETUAL JUNE ROSE}

Fra॥ Karl Druischki-Pure Snow White

George Dickson-Velvet Blk. Scarlet Crimson. Red

\section{HARDY CLIMBING ROSE}

Bess Lorett-Light Crimson Red

Climb. Imer. Beauty-Medium Pink

Climb. Carline Testout-Satiny Rose Pink

Climb. K. A. Victoria-Lemon White

Dr. W. Van Fleet-Delicate Flesh Pink

Emily Gray-Deep Golden Buff
Gardenia-Creamy Yellow

Mary Lorett-Waxy White

Yary Wallace-Bright Pink

Panls Scarlet Climber-Scarlet Red

Silver Moon-Silvery White with Brigh: Yellow 


\section{ROCK GARDEN PLANTS}

\section{Botanical Name}

Achillea tomentosa

Alyssum rostratum

Alyssum saxatile

Anemone pulsatilla

Aquilegia caerulea

Arabis alpina

Armeria formosa

Aster alpinus

Aster Mauve Cusion

Aubretia. hybrids

Baptista australis

Campanula carpatica

Cerastium tomentosum

Chrianthus allioni

Dianthus caesius

Dianthus deltoides

Dianthus plumarius

Dicentra eximia

Dicentra spectabilis

Erinus alpinus

Gypsophila repens

Helianthemum mutabile

Heuchera brizoides

Hypericum mosianum

Iberis gibraltarica

Iberis Sempervirens

Limonium latifolium

Lychnis alpina

Lychnis viscaria

Iyosotis alpestris

Myosotis scorpioides

Nepeta mussini

Pachysandra

Phlox amoena

Phlox Sublata

Primula acaulis

Primula denticulata

Saxifraga cordifolia

Saxifraga macabiana

Sedum acre

Sedum album

Sedum hispanicum

Sedum reflexum

Sedum Sieboldi

Sedum spectabile

Sempervivum arachnoideum

Thymus album

Veronica teucrium

Veronica rupestris

Veronica repens

Vinca Minor

Vinca Minor alba

Viola, cornuta
Common Name

Woolly Yarrow

Yellowhead Alyssum

Goldentuft

Pasqueflower

Colorado Columbine

Rockcress

Cushion Pink

Rock Aster

False Rock Cress

Wild Indigo

Bellflower

Snow-in-summer

Siberian Wallflower

Cheddar Pink

Maiden. Pink

Grass Pink

Fringed Bleedingheart

Bleedingheart

Liver-balsam

Creeping Gypsophila

Fickle Sunrose

Pinkbells

Goldflower

Gibraltar Candytuft

Evergreen Candytuft

Bigleaf Sea-Lavender

Arctic Campion

German Catch-Fly

Forget-me-not

Forget-me-not

Moss Pink

English Primrose

Himalayan Primrose

Hearleaf Saxifrage

White, spotted red

Goldmoss

White Stonecrop

Spanish Stonecrop

Jenny Stonecrop

Siebold Stonecrop

Showy Stonecrop

Spiderweb Houseleek

White Mt. Thyme

Hungarian Speedwell

Rock Speedwell

Creeping Speedwell

Periwinkle

Periwinkle

TuftedPansy color

Yellow

Yellow

Yellow

Lilac

Blue and White

White

Pink

Blue

Mauve

Pink-Blue-Lav.

Dark Blue

Light Blue

White

Orange

Rose

Pink

Pink to White

Pink

Pink

Rosy Purple

White

Pink

Pink

Golden Yellow

Lilac

White

Blue

Pink

Crimson

Pale Blue

Pale Blue

Mauve

Greenish-white

Bright Pink

Pink

Lemon Yellow

Purple

Pink

Bright Yellow

White

Pinkish White

Yellow

Rose-pink

Pink

Red

White

Blue

Deep Blue

Blue

Iilac Blue

White

Blue

\section{Height Blooming \\ inches Time}

6-8 July-Sept.

12 June-Aug.

12 April-May

12 April-May

18 May-June

5 April-May

12 Spring-Fall

6 May, June

9 October

6 April, May

24 June

8 July, Aug.

12 May, June

12 May-Midsummer

12 June, July

15 May, July

18 All Summer

24 All Summer

24 April-June

6 April-June

6 June-July

12 April

18 May-Sept.

18 June-Sept.

12 May-June

10 April, Maoy

24 Aug., Sept.

6 May

24 June, July

8 May, June

12-18 May, June

12 All Summer

6-9 May or June

4-6 April-May

4-6 April, May

6-12 April, Мау

10-12 April, May

12-15 April, May

12 May, June

2-3 May, June

2-3 May-July

3-4 June, July

2-3 July

9 Aug., Sept.

18 Aug., Sept.

6 May, June

3-4 June, July

6-12 May-June

4 May, June

2-4 May

8 April, May

8 April, May

6-8 All Summer 


\section{LIST OF SHRUBS FOR FOUNDATION PLANTING}

Numbers in column at left of table refer to locations to which each shrub is best adapted. Below is an explanation of each key number.

1. Accent. Used at house corners and at intersection of house and porch.

2. Used at front corners of front porch.

3. Next to foundation between accent points.

4. Dwarf edging plants.

5. Used in mixed plantings of shrubs and evergreens.

\begin{tabular}{|c|c|c|c|c|}
\hline Key No. & Name of Plant & $\begin{array}{l}\text { Ultimate } \\
\text { height in } \\
\text { feet }\end{array}$ & $\begin{array}{l}\text { Color of } \\
\text { Bloom }\end{array}$ & $\begin{array}{r}\text { Season } \\
\text { Bloom }\end{array}$ \\
\hline $2-5$ & Berberis thunbergi (Japan Barberry) & $3-4$ & Rea Berries & Fali \\
\hline $2-4-5$ & Deutzia gracilis & $2-3$ & Pink & JuIy \\
\hline $2-4$ & Deutzia lemoinei & $3-4$ & Wnite & July \\
\hline $1-3$ & Kerria japonica & $5-6$ & Yellow & June \\
\hline 3 & Kerria (white) & $4-5$ & White & July \\
\hline $3-5$ & Ligustrum ibota (Ibota Privet) & $4-5$ & No bloom & \\
\hline $3-5$ & Ligustrum ibota regelianum (Regal Privet) & $4-5$ & No bloom & \\
\hline $1-3$ & Lonicera fragrantissima & $4-5$ & Yellow & May \\
\hline 1 & Philadelphus lemoinei (Mockorange) & $5-6$ & White & July \\
\hline 3 & Rosa rugos alba & $4-5$ & White & Periodic \\
\hline 3 & Rosa rugosa rubra & $4-5$ & Red & Periodic \\
\hline $2-4$ & Rose F. J. Grootendorst & $2-3$ & Red & Periodic \\
\hline 3 & Spirea arguta & $4-5$ & White & May \\
\hline $2-4-5$ & Spiraea Anthony Waterer & $2-3$ & Red & July \\
\hline 3 & Spiraea billardi & $4-5$ & Pink & June \\
\hline $2-4$ & Spiraea callssa alba & $2-3$ & White & Juiy \\
\hline $3-4$ & Spiraea froebeli & $3-4$ & Pink & July \\
\hline $1-3$ & Spiraea prunifolia & $5-6$ & White & June \\
\hline 1 & Spiraea reevesiana & $5-6$ & White & June \\
\hline $2-4-5$ & Spiraea thubergi & $3-4$ & White & June \\
\hline $1-5$ & Spiraea vanhouttei & $5-6$ & White & June \\
\hline $1-5$ & Symphoricarpos racemosus (Snowberry) & $4-5$ & White Berries & August \\
\hline $3-5$ & Symphoricarpos vulgaris (Coralberry) & $4-5$ & Red Berries & August \\
\hline 1 & Weigela amabilis & $5-6$ & Fleșh & July \\
\hline 1 & Weigela rosea & $5-6$ & Pink & July \\
\hline $3-5$ & Weigela Eva Rathke & $3-4$ & Red & July \\
\hline
\end{tabular}




\section{EVERGREENS FOR FOUNDATION PLANTING}

\section{This table keyed same as shrub table}

\begin{tabular}{|c|c|c|c|}
\hline Key No. & Name of Evergreen & $\begin{array}{l}\text { Ultimate } \\
\text { Height } \\
\text { in Feet }\end{array}$ & $\begin{array}{l}\text { General } \\
\text { Characteristics }\end{array}$ \\
\hline $1-5$ & $\begin{array}{l}\text { Arborvitae, American (Thuja occi- } \\
\text { dentalis) }\end{array}$ & 20 & $\begin{array}{l}\text { A beautiful plant; vigorous } \\
\text { grower, bushy. }\end{array}$ \\
\hline $2-3-4-5$ & $\begin{array}{l}\text { Arborvitae, Pyramidal ( } \mathrm{T} \text {. occidentalis } \\
\text { globosa) }\end{array}$ & $2=3$ & $\begin{array}{l}\text { Grows in low, thick globe } \\
\text { form. }\end{array}$ \\
\hline $2-3-4-5$ & $\begin{array}{l}\text { Arborvitae, Compact ( } \mathrm{T} \text {. orientalis } \\
\text { compacta) }\end{array}$ & $2-3$ & $\begin{array}{l}\text { Low, somewhat pyramidal, } \\
\text { compact grower. }\end{array}$ \\
\hline $1-5$ & $\begin{array}{l}\text { Arborvitae, Pyramidal ( } \mathrm{T} \text {. occidentalis } \\
\text { pyramidalis) }\end{array}$ & 15 & $\begin{array}{l}\text { Same as American except } \\
\text { pyramidal in shape. }\end{array}$ \\
\hline $2-3-5$ & $\begin{array}{l}\text { Arborvitae, Hovey (T. occidentalis } \\
\text { hoveyi) }\end{array}$ & $3-4$ & $\begin{array}{l}\text { Dwarf, globular outline; gold- } \\
\text { en green foliage. }\end{array}$ \\
\hline $3-\tilde{5}$ & $\begin{array}{l}\text { Arborvitae, Siberian (T. occiden- } \\
\text { talis siberica) }\end{array}$ & 10 & $\begin{array}{l}\text { Very hardy, compact and } \\
\text { broad pyramidal. }\end{array}$ \\
\hline $3-\tilde{5}$ & $\begin{array}{l}\text { Arborvitae, Tom Thumb (T. occiden. } \\
\text { ellwangeriana) }\end{array}$ & 2 & Very small and of slow growth \\
\hline $1-3$ & $\begin{array}{l}\text { Juniper, Irish (Juniperus communis } \\
\text { hibernica) }\end{array}$ & $5-8$ & Erect, dense, narrow grower. \\
\hline $2-4$ & Juniper, Pfitzer (J. pfitzeriana) & $3-4$ & $\begin{array}{l}\text { Dwarf, horizontal } \\
\text { feathery foliage. }\end{array}$ \\
\hline 4 & $\begin{array}{l}\text { Juniper, Prostrate (J. communis de- } \\
\text { pressa) }\end{array}$ & $1-2$ & A trailing evergreen. \\
\hline $4-5$ & Juniper, Savin (J. sabina) & $2-3$ & $\begin{array}{l}\text { Spreading branches; } \\
\text { green foliage. }\end{array}$ \\
\hline $1-3$ & $\begin{array}{l}\text { Juniper, Swedish (J. communis sue- } \\
\text { cica) }\end{array}$ & $5-8$ & $\begin{array}{l}\text { Like Irish Juniper; a little } \\
\text { more bushy. }\end{array}$ \\
\hline 4 & $\begin{array}{l}\text { Juniper Tamarix Savin (J. tamarisci- } \\
\text { folia) }\end{array}$ & $1-2$ & Trailing variety. \\
\hline $2-4$ & Pine Mugho (Pinus montana mughus) & $2-3$ & $\begin{array}{l}\text { Low, dense, globe } \\
\text { grower. }\end{array}$ \\
\hline $3-5$ & $\begin{array}{l}\text { Retinospora, Goldenplum (Chamaecy. } \\
\text { pisif. plum. aurea) }\end{array}$ & $10-15$ & $\begin{array}{l}\text { Bushy, feathery, } \\
\text { foliage. }\end{array}$ \\
\hline $3-5$ & $\begin{array}{l}\text { Retinospora, Plume (Chamaecy. pisi- } \\
\text { fera plumosa) }\end{array}$ & $10-15$ & $\begin{array}{l}\text { Bushy, feathery, blue-greem. } \\
\text { foliage. }\end{array}$ \\
\hline $2-3-4$ & $\begin{array}{l}\text { Yew, Dwarf Japanese (Taxus cuspi- } \\
\text { data nana) }\end{array}$ & $2-3$ & $\begin{array}{l}\text { Spreading variety dwarf } \\
\text { growth, dark green. }\end{array}$ \\
\hline 3 & $\begin{array}{l}\text { Yew, Upright (Taxus cuspidata) } \\
\text { May be kept low by clipping. }\end{array}$ & $3-6$ & $\begin{array}{l}\text { As above, but more upright } \\
\text { growth. }\end{array}$ \\
\hline
\end{tabular}




\section{FIELD SEED}

\section{CLOVERS}

(Subject to Variation in Price)

Red Clover. Medium (Trifolium pratense). Price variable, $60 \mathrm{lbs}$. to bushel.

Red Clover, Large or Pea Vine. Price variable.

Alfalfa or Lucerne. Requires a deep rich soil, and in such will produce several crops every season. Fifteen pounds to the acre.

Alsike or Swedish (Trifolium hybridum). Ten pounds to the acre.

Crimson or Italian (Trifolium incardatum), sown in Autumn, it furnishes an early fodder and is excellent for soiling. Twenty pounds to the acre. Price variable.

\section{SPRING WHEAT, 60 1b. Bushel}

Marquis Spring. This variety has been grown with great success for a number of years in Can. ada, and is very highly recommended, is beared, yields well and the kernels are larger than those of other Spring varieties. Market price.

\section{WINTER WHEAT, 60 1b. Bushel}

Red Mediterranean. (American). This is the imported variety fully acclimated and is a standa wheat. The heads are beared and well filled. It succeeds well in nearly all localities and ripens early.

OATS, 32 lb. Bushel

Swedish. Very popular and standing well until fully ripe.

\section{SPRING AND WINTER RYE, 56 lbs. to Bushel \\ FIELD PEAS, 60 lbs. to Bushel}

Canadian Field Peas. Valuable for Northern climates for cattle-feeding and for green soiling. Sow 3 bus. per acre alone, or $1 \frac{1 / 2}{2}$ bushels with 1 bu. oats.

\section{VETCHES, 60 lbs. to Bushel}

Vetches, or Tares, Spring (Vicia Sativa). Highly valuable for soiling or for green manuring. Use 2 to 3 bushels to acre, broadcast, or 1 to 2 bushels in drills.

Vetches, or Tares, Winter (Vicia Villosa). Also called Sand Vetch, or Hairy Vetch. A sreat soil improver, and a nutritious green fodder or hay crop. For Fall sowing. Sow 1 bushel per acre, with 1 bushel of rye.

\section{BUCKWHEAT, 48 lbs。 to Bushel}

Japenes. Earlier, more prolific and yields nearly double the weight per acre of otier sorts.

Golden or German Millet. This variety is a heavier cropper than the Hungarian Grass, and needs a longer season and stiffer soil. Grows from three to five feet high, stands up well, is easily cured. Three pecks to the acre. Per bushel of 48 lbs. Market Price.

Japanese Millet. Frequently as high as 12 tons of green food have been obtained from an acre It is somewhat coarse in texture, growing sometimes as high as 8 feet; it is, however, idea' for silo or hay purposes. If sown early in May, it may be cut twice in one season. Sow 12 lbs. per acre broadcast. $32 \mathrm{lb}$. per bushel. Market Price.

Hungarian Grass. A valuable rorage plant, succeeds well on dry, light soil; withstands the drought remarkably, remaining green when all other vegetation is parched up, and if its development is arrested by dry weather, the least rain will restore it to vigor. Sow broadcast. Three pks. to the acre. Per bushel of $48 \mathrm{lbs}$. Market Price.

\section{MEADOW AND PASTURE SEED}

The formation of permanent and productive meadows and pastures is of great value to farmers, and has been given thorough study by numberous experts, resulting in formulas that will give good results under the varying condition of our climate and soils.

\section{MEADOW MIXTURE FOR ONE ACRE}

\section{No. 1. On Good Land}

Neither Too Dry nor Too Wet

Price $\$ 15.00$ for $40 \mathrm{lbs}$. Sow $40 \mathrm{lbs}$. to the acre.

No. 2. For High and Dry Land

Price $\$ 15.00$ for $40 \mathrm{lbs}$. Sow $40 \mathrm{lbs}$. to the acre.

No. 3. On Wet Land

Price $\$ 15.00$ for $40 \mathrm{lbs}$. Sow $40 \mathrm{lbs}$, to the acre.

\section{PASTURE MIXTURE FOR ONE ACRE}

\section{No. 4. On Good Land}

Neither Too Wet nor Too Dry

Price $\$ 15.00$ for $40 \mathrm{lbs}$. Sow $40 \mathrm{lbs}$. to the acre.

No. 5. On Dry Land

Price $\$ 15.00$ for $40 \mathrm{lbs}$. Sow $40 \mathrm{lbs}$. to the acre.

No. 6. On Wet Land

Price $\$ 15.00$ for $40 \mathrm{lbs}$. Sow $40 \mathrm{lbs}$. to the acre. 


\section{GARDEN SUPPLIES}

Ornamental Gates are made to match any of our styles of fabric.

$36 \times 36$ Plain \$...\$3.0C

$42 \times 36$ Plain 3.50

$36 \times 36$ Fancy 3.75

$42 \times 36$ Fancy 1.00

$42 \mathrm{x} 42$ Fancy $3.9 \mathrm{C}$

$48 \times 36$ Fancy 4.50

42 in. $x 10 \mathrm{ft}$ 10.00

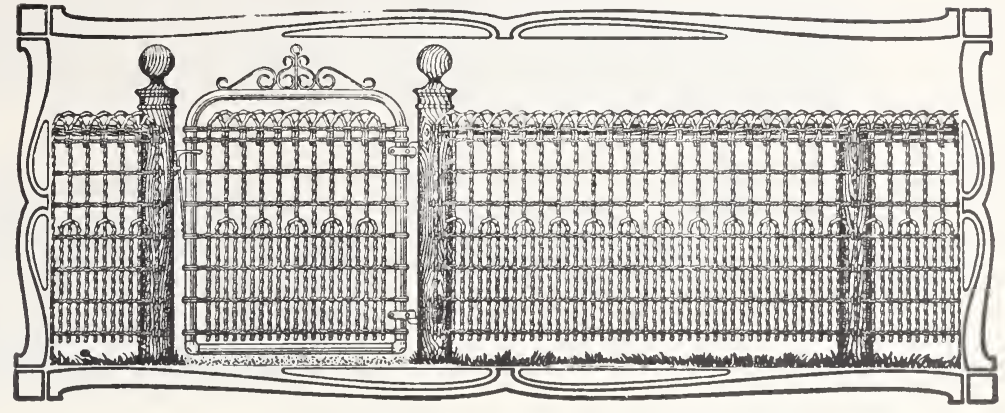

FEN CING

STYLE 100 WITHOUT LOWER WEAVE

36 inches high............................................................................11c lineal foot-Roll 8c it. 42 inches high..............................................................................13e lineal foot-Roll 10c ft.

Our Ornamestal Fences are exclusive in lesign, and embody many highly meritorious features not to ke found in those of any other manufacture.

STYLE 600-SAME AS CUT ABOVE

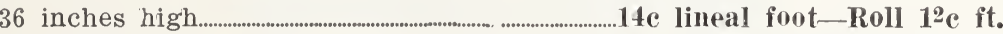

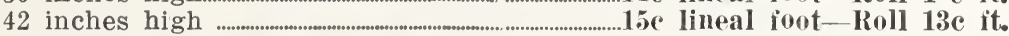
48 inches high....................................................................................18c lineal foot-Roll 14c fit.

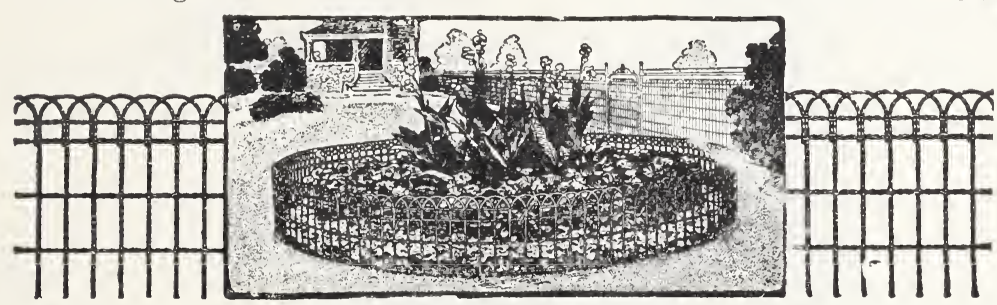

FLOWER BED GUARD

A neat, artistic, and inexpensive fabric for the protection of flower beds. Also much used for lawn and curbway border. Can be readily taken up and used from year to year, cut off to length required, and the ends hooked together when set. 22 inches, 10c per ft.; Roll, 8c per it.; 16 inches, 9c per ft.; Roll 7c per ft.

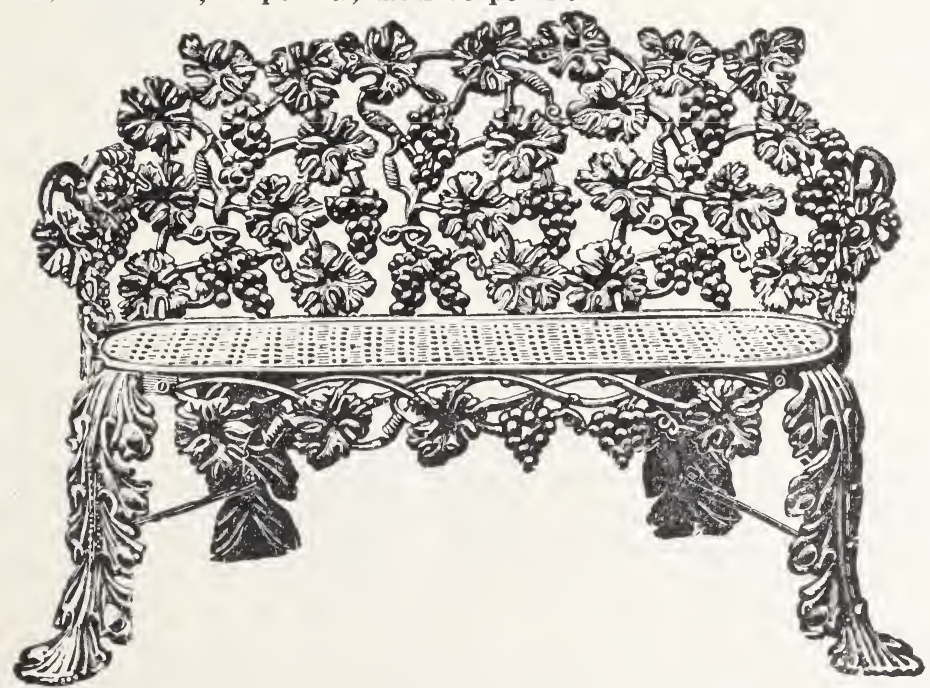

\section{National Farm} Fence

45 inches $6,(3)$

32 inches 5..5"

(10 rods to roll)

\section{National Poultry Fence}

48 inches $\$ 6.50$

58 inches 7.98

(10 rods to roll)

Cemetery Settees, Chairs, Urns, Etc.

(Prices on Request) 


\section{Planet Jr. GardenTools}

\section{THE

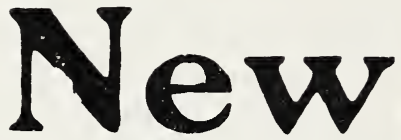

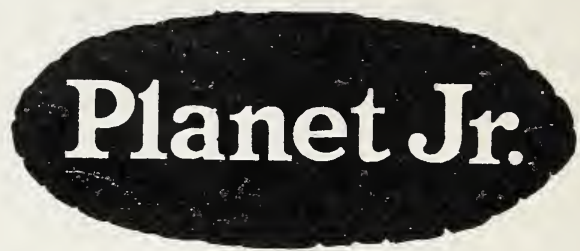

The New Planet Jr. is of exclusive design; an improved model built and guaranteed by Planet Jr. engineers as the nearest approach to an "All Purpose Tractor." It is easily adjustable to various needs-from fine work in narrow rows to the pull of a 6 " to 8" plow under average soil conditions. Swift, accurate and eff icient to a high degree, it pays for itself in service performed in a short time. We sugzest that you stop in and see one of these new models next time you are in the neighborhood.

\section{MOTOR CULTIVATOR}

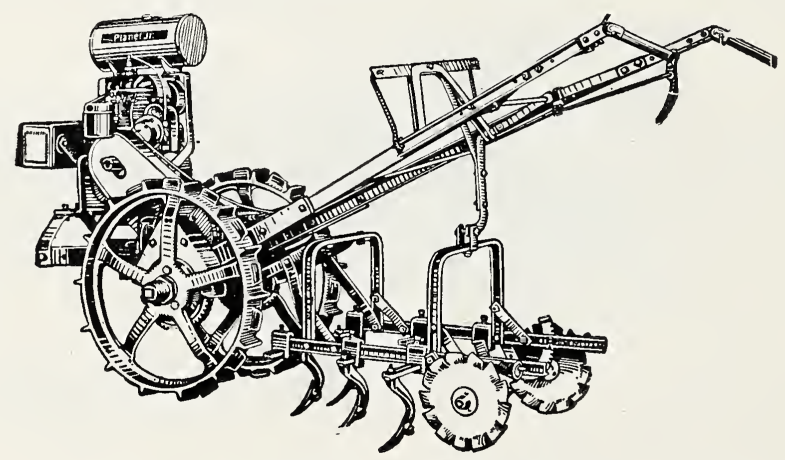

No. 300 Seeder-Is a very efficient plate seeder intended primarily for the market gardener and large vegetable grower. It is designed for \& ny soil-heavy, sandy, or muck-and will do excellent work in either. Price $\$ 20.00$

No. 25 Hill and Drill Seeder, Double and Singli Wheel Hoe Combined-Here is "The complete gardener." Price

No. 12 Double and Single Wheel Hoe Combined-The No. 12 is a great favorite with home gardeners and market gardeners. Used as a Double Wheel Hoe it straddles the row until plants are 20 inches high. Price...

$\$ 10.75$

No. 11-Same as No. 12 with a pair of $4 \frac{1}{2}$ inch hoes and two pairs of rakes added to the above equipment. Price

$\$ 13.75$

Fire Fly Garden Plow-Very useful for plowing up the home garden or plowing up poultry yards. Price

No. 7 Horse Hoe-Designed to do a great variety and better work than any other Horse Hoe available for your use. Price...

$\$ 15.75$

No. 8 Horse Hoe and Cultivator Combined-Complete with a depth regulator. Price.................\$16.25

Yo. 82 Seven-Tooth Horse Hoe and Cultivator Combined. Price ...........................................................................\$15.75

No. 90-Twelve-Tooth Harrow, Cultivator and Pulverizer-A harrow that has proved its time and labor saving value to commercial growers. Price ...............................................................................................\$17.00

No. 90B-Same as the No. 90, less the pulverizer. Price ......................................................................................................\$13.75

No, 90D_-Same as the No. 90, less pulverizer and steel wheel. Price ..........................................................\$10.75

No. 101-Plain Cultivator-The No. 101 is simrle, strong and easily handled. Light so that the operator can lift the cultivator and work the side of the ridge, close under the leaves. Price 


\section{Planet Jr: Garden Tools}
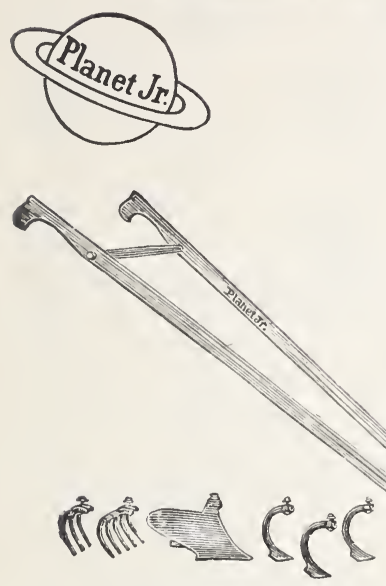

No. 16 Single Wheel Hoe-Here is a very complete, light running cultivating tool suitable for either the home or market garden

$\$ 9.00$

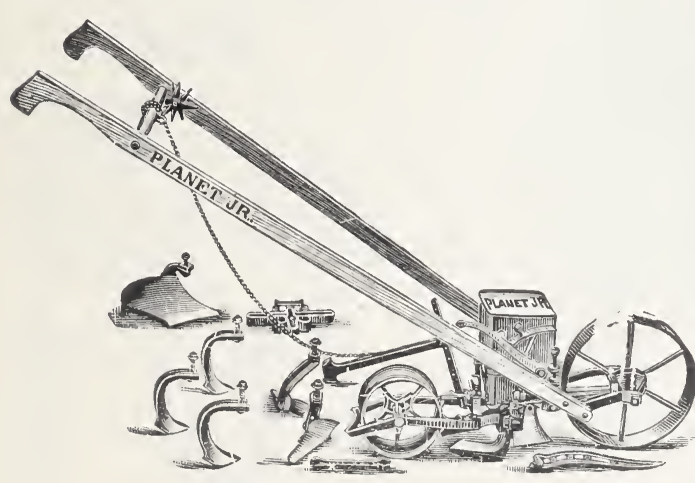

No. 4 Hill and Drill Seeder and Single Wheel Hoe-Here is a wonderful combination for the home gardener or the small market gardener $\$ 18.0 r$

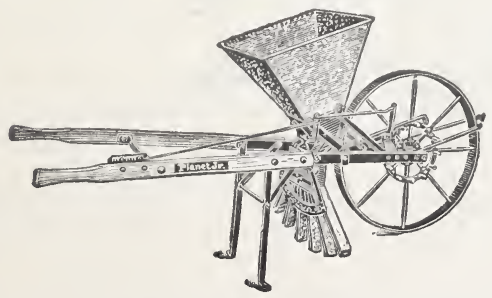

No. 220 will distribute fertilizer in the middles of three rows 12 to 14 ins. apart; it will side-dress 1 side each of 2 rows up tr 36 ins. apart $\$ 27.00$
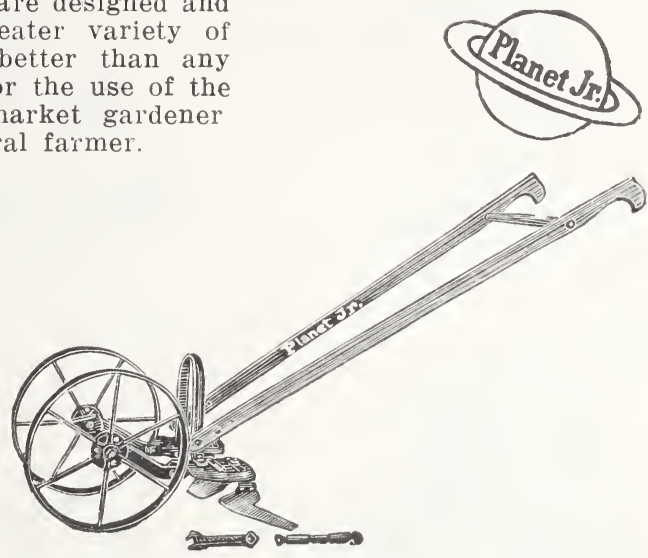

No. 13-A double and Single Wheel Hoe combined with a pair of 6 -inch hoes only. The hoes are sure death to weeds........................\$8.00

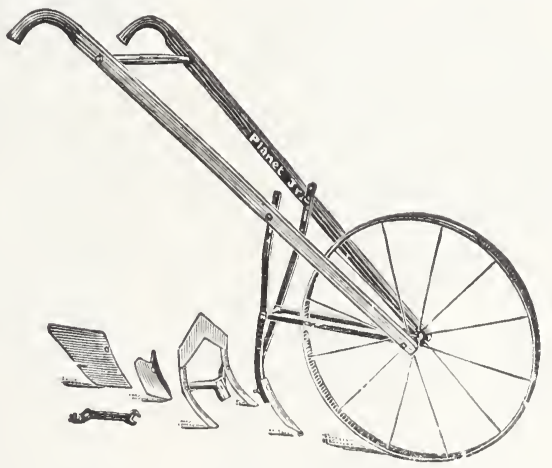

No. 119 Garden Plow and Cultivator-For those who prefer a high wheel garden cultivator

$\$ 4.75$

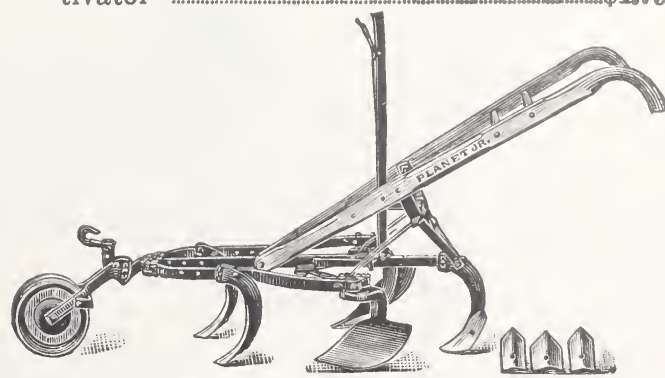

No, 9 Horse Hoe-The No, 9 is a valuable practical tool; identical with No. 7 except that it has a plain wheel instead of a lever wheel. Popular because of its strength lightness, easy change of width and perfection of work $\$ 14.25$ 


\section{GARDEN SUPPLIES}

\section{Bamboo Stakes BAMBOO}

These Stakes are very strong and durable.

Natural Color.

4 feet, per doz., 75c.; per $100, \$ 4.00$.

6 feet, per doz., 80c.

8 feet, per doz., \$1.25; per $100, \$ 8.00$.

\section{Green}

30 inches, per doz., 25c; per $100, \$ 1.25$; per 1,000 $\$ 7.00$.

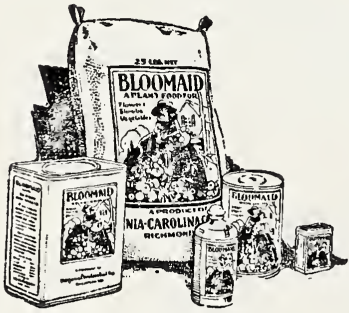

\section{BLOOMAID}

Use it in the vegetable garden, around shrubs and to enrich the soil in window boxes and flower pots

Fifteen times as rich as manure; does not bring in weed seed or the spores of plant diseases.

Bloomaid Prices

Tablet Form (125 Tab-

lets) (....................................\$ .25

Liquid Form (8-0z.

Bottle) .................................... .5r

Pulverized Form:

1-1b. Can ....................................25

5-lb. Container...................5

25-1b. Bag ............................. 1.7F

100-1b. Bag ........................... 5.00

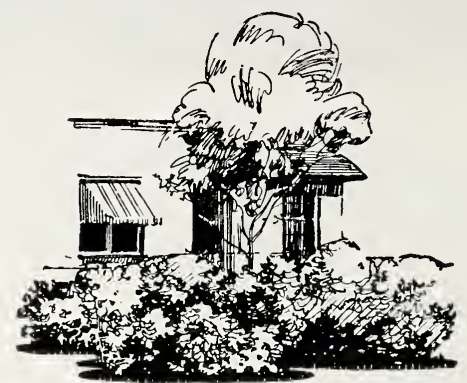

FOR BETTER FLOWERS AND MORE OF THEM

Use good seed, bulbs and plants and feed them Vigoro the complete. balanced diet. Feed your lawn vegetables, shrubs, and trees, too.

Clean, odorless, easy to use, and economical.

VIGORO

Complete plant food

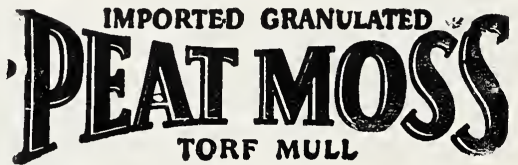

Assures better lawns and gardens It will lighten and make more friable clay soil and will help to retain the moisture in sandy soil. Use

it wherever a mulch is needed. Twine

Bunching Twine For bunching carrots, beets, radish, e t c. Has 50-2 ply ends. On reels of about 50 lbs. (Extremely low price to market gardeners).

\section{Raphia}

$\mathrm{H}$ as $\mathrm{great}$ strength and is not affected by outdoor e x p o sure. Also much used for basketmaking. Naturaı color only.

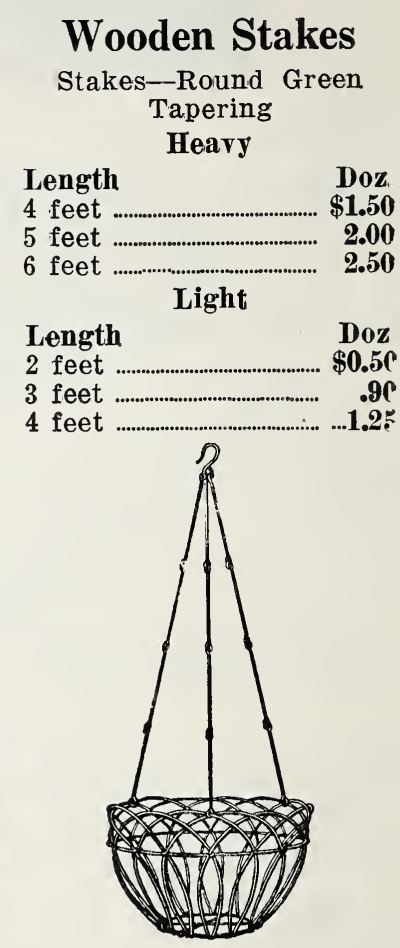

Wire-Hanging

Green finish, strong and well-made, just the thing for decorating piazzas of hotels and summer residences.

\begin{tabular}{|c|c|c|}
\hline Size & Each & Dozen \\
\hline 8 inch & $\ldots . . . . . . . . .30 c$ & $\$ 3.00$ \\
\hline 0 inch & 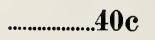 & 4.00 \\
\hline inch & 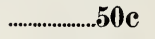 & 5.00 \\
\hline 5 inch & $\ldots . . . . . . . . . .65 c$ & 6.50 \\
\hline
\end{tabular}

\section{Water Pots}

Regular

4 qt.Capacity $\$ .69$ 6 qt.Capacity $\quad \mathbf{7 5}$ 8 qt.Capacity $\mathbf{8 5}$ 10 qt. Capac. $\quad .98$ 12 qt. Capac. $\mathbf{1 . 2 5}$ 16 qt. Capac. 148 Green Japanned

Wheelbarrow

Tree, $3 \frac{1}{2}$ inch copper wired, painted, per 100 . 50c: $500, \$ 1.50$ : $1,000, \$ 2.50$.
1,000 6.50 10.00 10.00

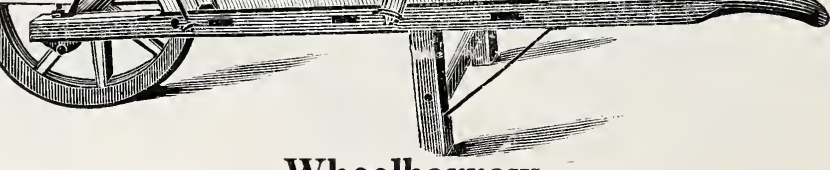

This barrow is light, strong and durable; is made of selected material, has steel wheel and axle, and is well painted. While its carrying capacity is from 300 to 500 lbs., its weight is less than 50 lbs. Fully warranted to stand rough usage and garden use. joes not sink into soft ground.
1 qt.Capacity $\$ .40$

2 qt.Capacity .48 4 qt.Capacity $\quad .60$ Fasicy Lq.

Spout (Colored) 1 qt. 1.06 
SPRAYERS

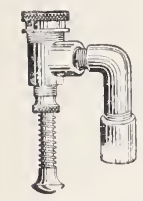

VERMOREY.

NOZZLE

Two carns for tine or coàrse spray. Impossible to clog, as obstructions are forced out with spring needle. For spraying. trees, shrubbery, etc. l'rice, \$1.2\%. Transportation paid.

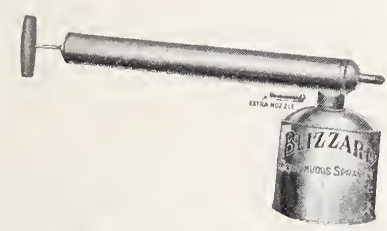

CONTHEOLS ITOMIZER

This Atomizer will spray insecticide in a continuous fog of such great volume that it will fill an ordinary room full of vapor in one minute. III Brass, 1 ut., with legs, $\$ 1.25$.

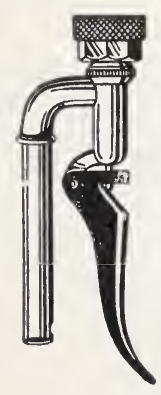

\section{IUTO-POP}

This patented device is a most convenient automatic shut-off attachment. Light pressure on lever turns spray on; releasing pressure shuts it off. Unlike stop-cock, can be operated by one hand. Saves solution and reduces labor.

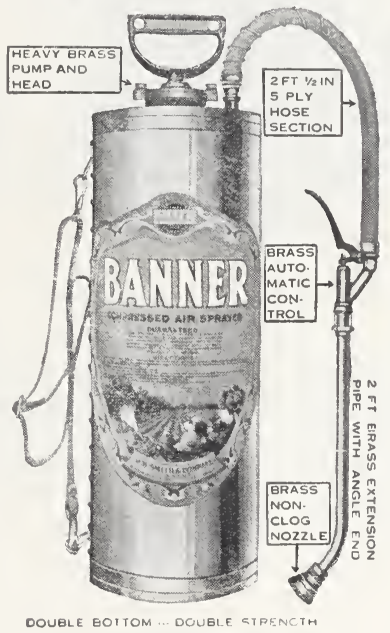

SPRIYER

Complete as shown

Tank in galvanized stee or solid brass. Large brass 2 inch pump cylinder. The best compressed air spray er made.

Galvanized $\$ 5,48$

Brass ..8.48

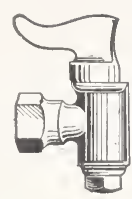

\section{BORIELIUX}

NOZZLE

Throws long distance spray, a solid stream or a fine mist and may be shut off altogether. For general spraying and fo $r$ whitewashing Impossible +o clog Price, \$1.00. Trans portation paid.

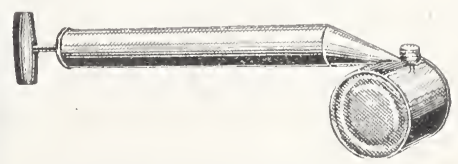

\section{LOWEII, SPRIYER}

It is substantially built of heavy tin and can be used for spraying all sorts of chemicals, for fumigating purposes, also for insecticides in the zarden. Price 296.
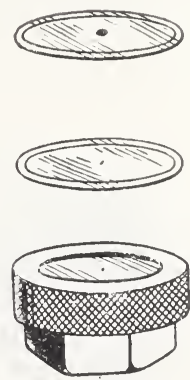

A TTO-SPRAY

NOZZLE

This is our patented standard nozzle for use with the Apto-Spray. It is light weight, will throw a very fine spray under low pressure, and is a real clog proof nozzle.

\section{BAMBOO EXTENSION ROD}

Fitted with non-corrosive tube $1 / 4$-in. diameter inside, with brass stop cock and drip guard. Price, 8 feet long, $\$ 4.00$; 10 feet long, $\$ 4.50$. 


\section{DUSTERS}

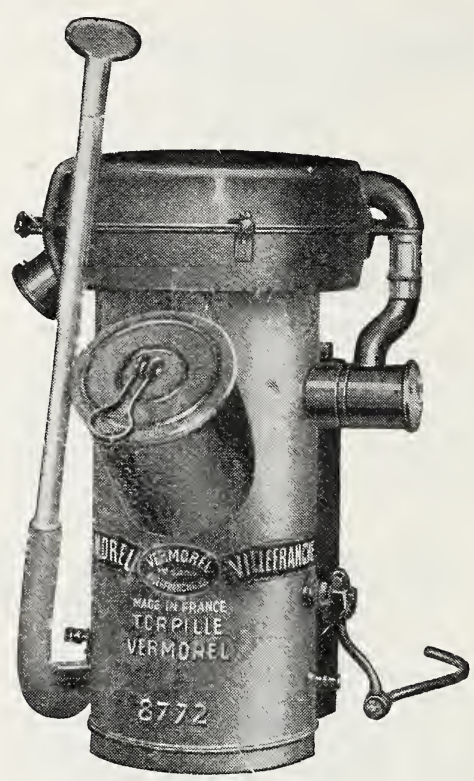

VERMOREL

"DOUBLE ACTION"

DUSTER

Vermorel Dusters are simple and compact, economical and efficient. For applying sulphur, arsenate of lead, calcium arsenate, Bordeaux Mixture, nicotine dust, etc., either of these models will give excellent results.

Double Action $\$ 16.00$

Single Action $\$ 12.00$

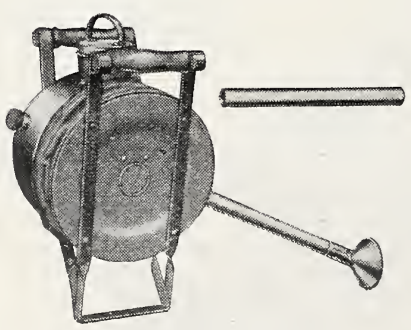

THE PLATZ DUSTER

Compact, sturdy, efficient, with capacity of 2 to 4 pounds. It is equipped with powerful bellows and a 30-inch extension pipe with sprayer. The wearing parts can be easily duplicated. It is excellent for dusting hills and has an attachment so that the powder reaches the under side of the foliage.

Price $\$ 6.00$

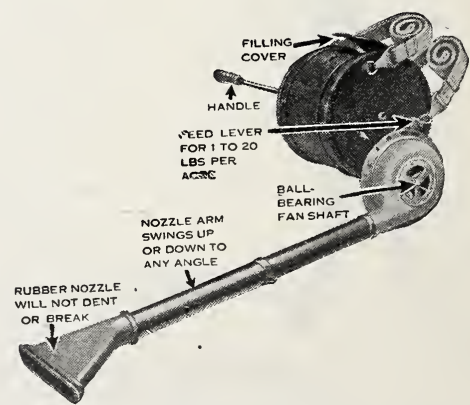

SHITH SAVAGE DUSTER

Fan and fan housing made of aluminum; fan works on ball bearings. Gears are machine cut bronze and encased in grease. Nozzle arm on swivel so can dust in front or rear of operator or upwards with smaller trees, etc. Feed lever to regulate adjustment from 1 to 20 lbs. poison. 


\section{SPRAYERS}

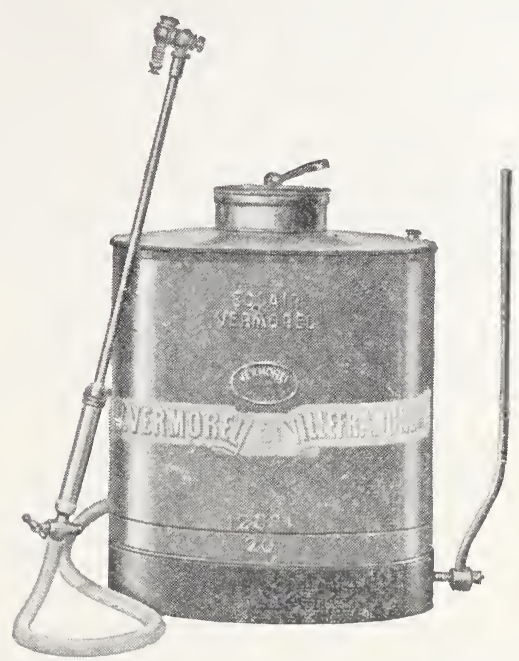

FERMOREI

ECLAIR No. 1 KNAPSICK

SPRAYER

The Eclair No. 1 Sprayer-Has no plunger nor complicated mechanism. Its simple diaphragm pump eliminates the usual pump troubles. Pressure can easily be maintained at forty pounds Furnished in either brass or copper.

Price $\$ 16.00$

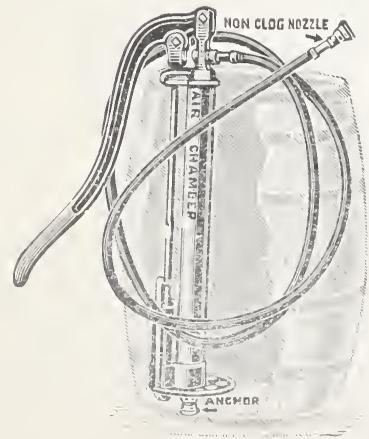

SMITH NO. 25 BARREL PUMP

Nozzles, cylinder, ball valves and valve seats entirely of brass. Double acting barrel of heavy brass. Pump not affected by strong mixtures. Pump quickly attached to any barrel.

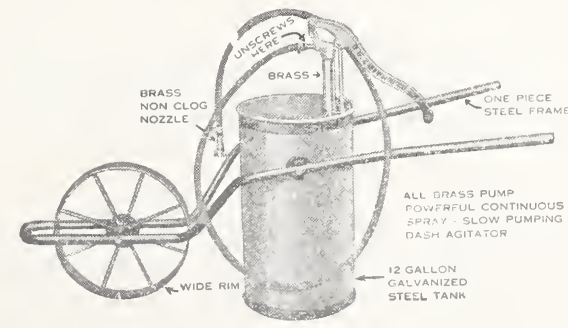

SMTTH No, อ̈0 WHEEIBARROW SPRIYER

12 gallon heavy galvanized tank, all brass pump, agitator, $8 \mathrm{ft}$. heavy hose, brass nozzle for two different sprays. Steei rrarne made in one piece, strong and rigid. A high grade well built Wheelbarrow Sprayer for small orchards and general spraying. Easily wheeled about. 


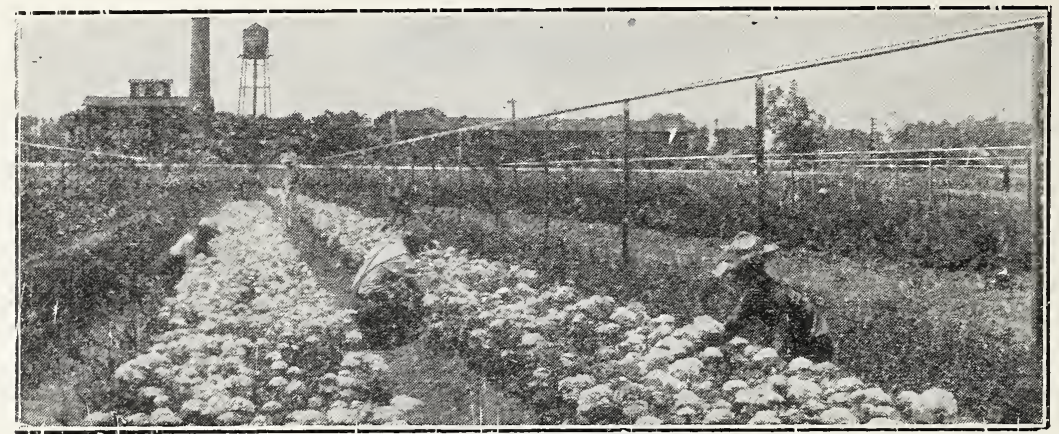

THE ANSWER TO THE RAIN QUESTION

\section{MARCH}

\section{SUPER SYSTEM IRRIGATION}

Reproduction of natural rainfall within 15 per cent. variation. Guaranteeing uniform even water distribution over field with maximum yield and quality possible to attain. (Closest competitor over 150 per cent.)

Dependable TURN-MOTORS. There are over 50 to 1 more March Turn-Motors in use than all competitors combined.

Complete SOLID BRASS EQUIPMENT. Everything but the pipes and posts them. selves made of this life-time lasting material and furnished only by us. Irrigation is not bought every day and 15 to 20 years more service is desirable as well as lowest in cost and maintenance.

LARGER SIZE PIPES IN LINES. (Smallest size 1 inch.) Better volume and water distribution along full length of line.

PATENTED LONG THROW NOZZLES INDIVIDUALLY SCREENED. (Five to 10 foot longer throw with same pressure.) Screens practically eliminate plugging up troubles.
GRADUATED S:ZE DISCHARGE NOZZLES. A special feature found only in MARCH SYSTEM. Worked out after three years' study and experimentation. Guaranteeing even water distribution.

AUTOMATIC FLUSH VALVE. (Patent applied for.) All lines drained and cleaner automatically with no attention. Eliminater clogging of pipes and nozzles. Prolongs life of system if water has lime or other chemical content.

NON-CLOGGING SELF-PACKING TURNING UNIONS of solid brass, non-corrosive and rust-resisting. A big feature and appreciated by every practical grower.

SIMPLICITY OF INSTALLATION. Very important to every buyer. With complete and understandable instructions and specifications the ordinary man does not need the ser. vices of a plumber. Work is done in half the ordinary time. We will also contract your job-get our estimates.

REMEMBER-Your only idea in buying ir. rigation is from the profit to be made from its use. If you buy on a bustness basis you will buy MARCH'S. 


\section{IRRIGATION}

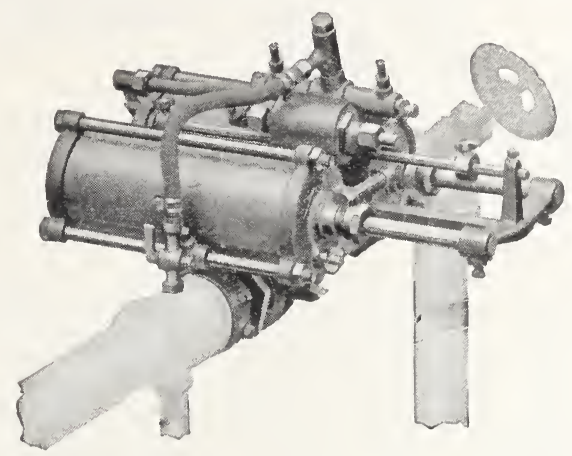

MARCH TWIN TURN MOTOR

Turn lines 300 feet long on 25 pounds pressure. Will turn lines up to 660 feet long. Guaranteed on 50 pounds pressure. Lines turn 2 to 3 times per minute depending on pressure. It is especially timed for frcst protection and is recognized throughout the country as the only successful FROST PROTECTION MOTOF.

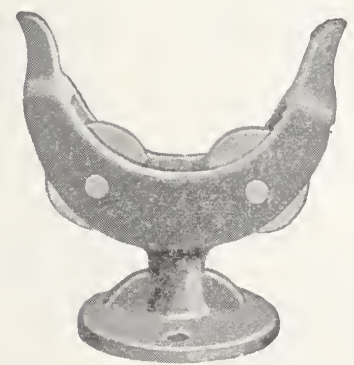

\section{WOOHEN POST HANGER}

MARCH'S HANGERS have several exclusive improvements. The main objecr of a hanger is to enable a pipe line to roll with least amount of friction and wear and to reduce wear on automatic Turn-Motor and to save water pressure. These hangers have 2 point ro!ler bearing. "Pin" extra large. Never is there a possibility of rusting. Are compiete brass throughout. Outlasts other hangers 30 years. Lasts a lifetime. Can be used with any make irrigation line.

\section{Price 42 cents each}

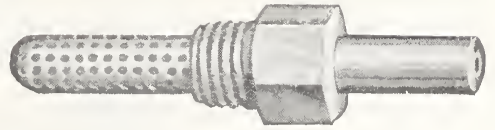

SCREENED FIELD NOZZLE

Since overhead irrigation was first used in field or greenhouse, user's were seriously troubled with clogged nozzles-keeping them clean and functioning so that every bit of ground would get its moisture and give ? maximum yield. It was a serious and expensive annoyance.

March's Nozzles have the added advantages of throwing 5 to 10 feet farther, thereby spac ing pipe line farther anart. Also an annealer flexible tip which can be bent to bring nozzle streams in line.

Field Nozzles, unscreened \$(i.00) per 10? Field Nozzles, all screened. 10.00 per 100 


\section{LAWN SUPPLIES}

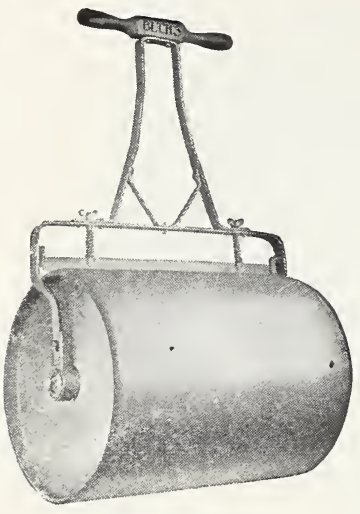

LAWN ROLLERS

Water Filled

Length and weight precisely as listed.

Rollers are smooth on face nd aluminum finished, outer edges rounded to avoid cutting up the lawn.

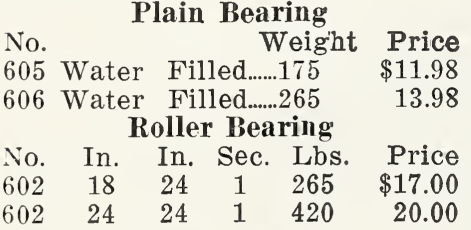

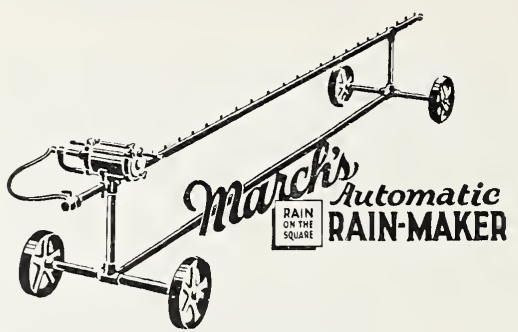

Thriving Beautiful Lawns are obtained with the RAIY-MAKER

The natural rainlike fall of water develops deeper root growth without disturbing soil. Dissolves soluble matter in fertilizer. No burning.

BEAUTIFUL FLOWERS SHRUBS and GARDENS are the result of watering the MARCH way. Your florist uses the Overhead System to produce prize-winning blooms. You, too, may enjoy the best with less labor.

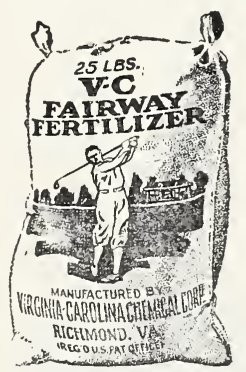

FERTILIZER

Fairway Lawn Fertilizer is fifteen times as rich as manure; costs not more than 10 cents for each 100 square feet to be treated. Practically no odor. Prices

100-1b. Bag (enough

for $5,000 \mathrm{sq}$. ft) ............\$5.00

50-1b. Bag (enough

for 2500 sq. ft.)............ $\mathbf{3 . 0 0}$

25-lb. Bag (enough

for 1,250 sq. ft.) ............ $\mathbf{1 . 7 5}$

10-1b. Bag (enough

for $25 \mathrm{sq}$. ft.) ................... $\mathbf{1 . 0 0}$

Convenient, easy to handle. 'Complete directions for lawn treatment on every bag.

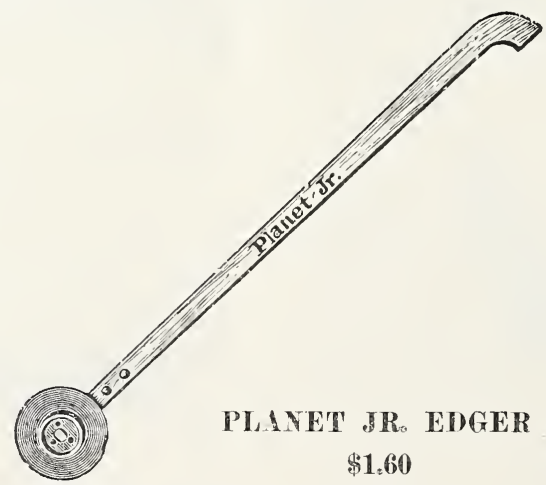

Neatness is the great secret of attractiveness in grounds surrounding a house, and to have this neatness the grass bordering walks must be frequently edged or trimmed. With a No. 2 Planet Jr. Edger you can edge either straight or curved walks of cement, stone or brick, rapidly and easily. Everyone who uses a lawn mower has work for one of these edgers. Works best if used after a good rain or watering.

It is always ready for use, and should be the constant companion of the lawn mower.

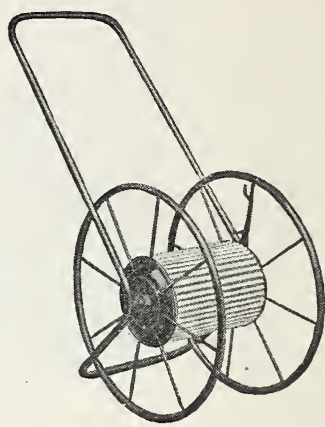

ILL IRON HOSE REEL

The All Iron Hose Reels are indestructible; light in weight; frictionless and are easily manipulated. These reels cannot tip over when unreeling, and there is no weight of hose to carry on the handle. Price $\$ 2.25$ up.

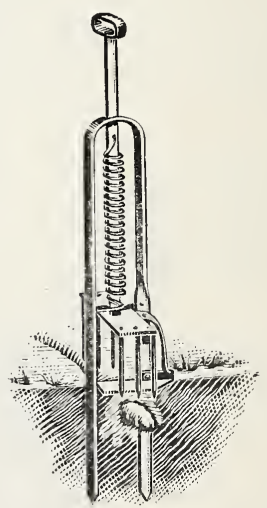

\section{Mole Trap}

Is easy to set and it will catch moles deep in thé ground, and there being no pin or other obstruction projecting into the run. there is nothing to frighten or disturb the mole as it passes, and in doing so raises the ground over the "run" just enough to spring the trigger Price \$1.48. 


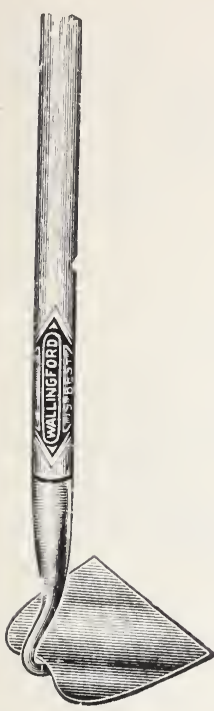

\section{GARDEN TOOLS}

It no time has there been a greater interest manifested in garden making than at present. Every year finds more ladies and young folk taking up this hobby, and it is well, for there is no exercise more beneficial or healthful.

REVERSIBLE STEEL LIWT RIKE Heavily tinned steel teeth. The arched teeth for leaves and litter and the opposite side for fine cut grass. $\$ 1.00$.

\section{WOODES RIKES}

Our wooden rakes are of a superior grade selected wood 3 bow, aluminum. $\$ 1.25$.

SOLII) BOW STEEL RAKES, electric welded bow, pinned through handle-12, 14 16 tooth. \$1.25 $11 \%$.

IIDII, STRAIGHT SHANK RIKE. The flanged head gives additional strength and is fine for leveling the dirt. 65c up.

HOES. Blades polished and hardened.

G.IRIEN MITTOCKS. It is heavier than the garden hoe and is indispensible for digging burdocks, grubbing out roots. \$1.48.

WARREX Or HEIRT SHAPE HOE arr unequalled for hoeing, weeding, cultivating making drills, etc. \$1.35.

IMPOR'TED ENGLISH SCUFFLFE HOE The blade pushes through the soil easily and cuts front and back. 4", 70c; 5", 75c; 6", 80c; $10 ", \$ 1.20$.

POTATO FORKS. Indispensible for digging root crops and forking over manure $\$ 1.19$.

SPADE. Fox standard quality steel smooth back, fully strapped No. 2 wood handle. $\$ 1.48$.

DIBBLES. All iron, hollow, for transplanting celery, cabbage, etc. 69c.

NURSERYMEN'S PLANTING SPADE Used for transplanting seedling trees shrubs, etc. Ideal for stony ground. \$1.48.
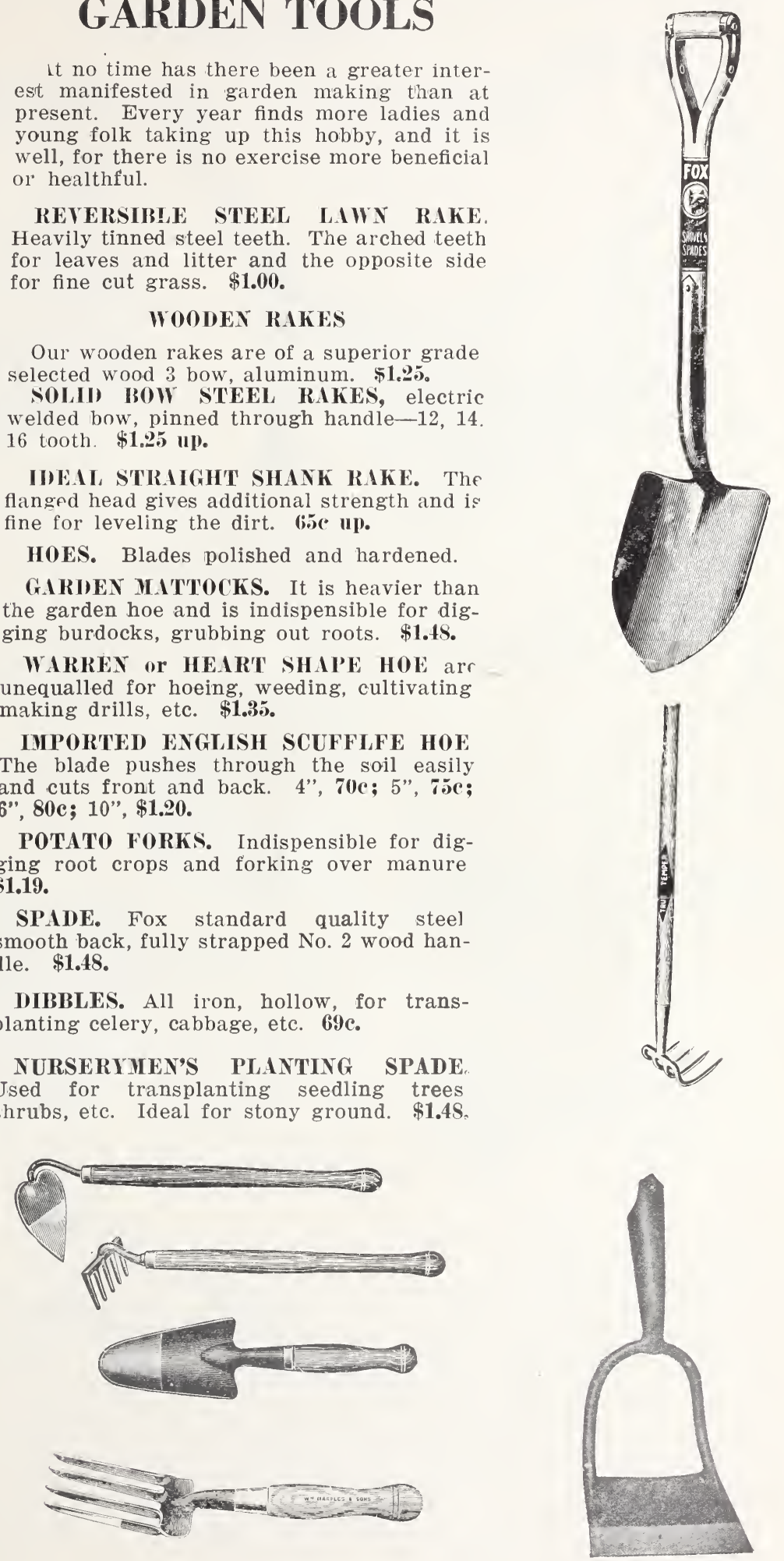


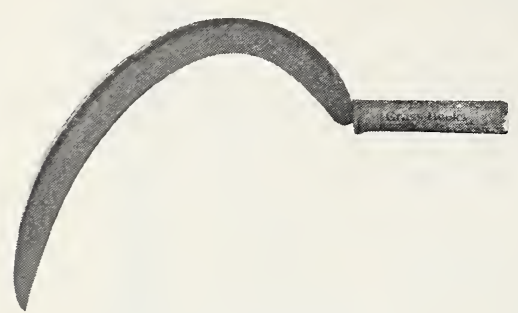

ENGLISH SICKEL

Imported English heavy riveted back thin cuttin $r$ blade made from best grade steel. Price 75c.

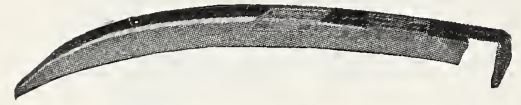

GREYHOUND BRAND, ENGLISH RIVETED BACK SCYTHES

Light and thin broad blades strengthened by a riveted back Price $\$ 2.75$.

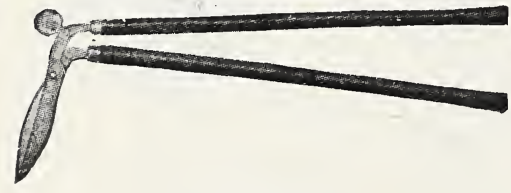

\section{BORDER}

For trimming the overhanging grass around the edges of walks etc. Price $\$ 1.98$ up。

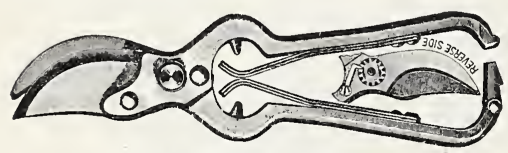

PRUNING SHEARS

A spring tension washer is provided to hold the shear in permanent adjustment, and a patented spring latch that opens the shear by mere pressure of the hand, holds it shut when not in use. Exceedingly useful for trimming the edges and borders of lawns, flower beds, etc. Price 59c up.

\section{SPEED ELECTRIC} HEDGE TRIMUER It operates so rapidly and accurately that no branches are ripped or torn. An expert can do little better than you. Blade is easily sharpened. Ready for operating when connected to an ordinary electric light socket. Prico \$45.00.

\section{CUTTING TOOLS \\ TELEPHONE TREE PRUNERS}

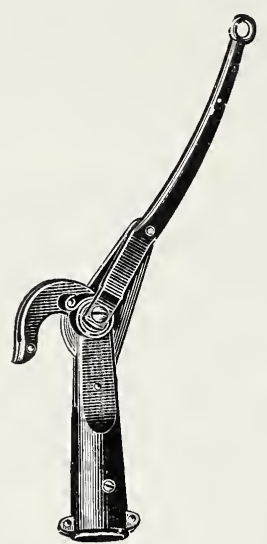

No. 1 attaches to pole of any length, operates with a cord; a spring throws knife back in position.

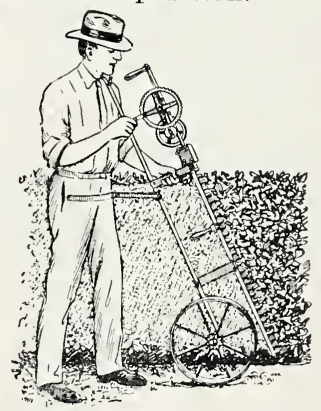

\section{LITTLE WONDER HEDGE TRIMUER}

Will trim your hedge five to ten times faster thar hand shears. Attachments come with each machine to adapt it to flat, round or pivot tops as well as side cutting; 40inch. Each, $\$ 27.50$.

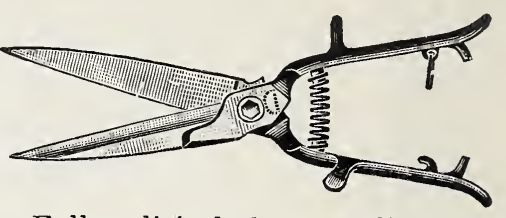

Full polished, best quality crucible steel blades, tempered, ground convex; adjusting nut and regulating ratchet; longitudinal double brass spring; removable handleclip. Price 59c.

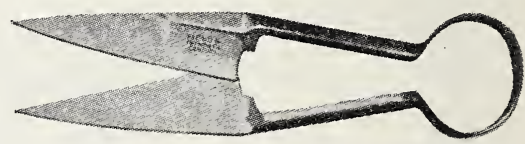

\section{EXTRA FINE POLISH TROWEL} SHANK

Solid steel of finest quality and tempered; 7-in. blades. The raised trowel-like handles keep the knuckles off the ground and allow smoother cutting. Price \$1.48.

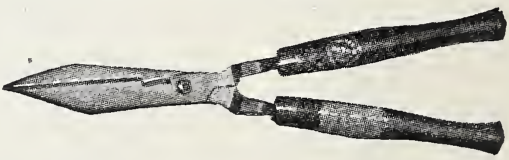

These shears can be used both for trimming hedres, and for cutting grass under fences, bushes, etc. The notch at the heel of the blade is used for cutting twigs and small branches. Price \$1.10 up.

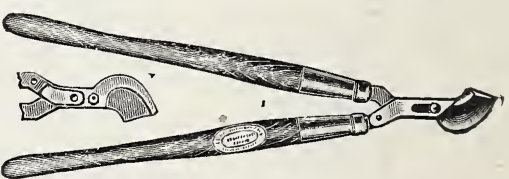

\section{DRAW CUT}

The Lopping Shear is made with two drop forgings of high grade tool steel, carefully hardened and ground and fitted with 26 -in. white ash handles, making a tool which is unsurpassed for cutting underbrush and limbs. Price $\$ \mathbf{\$ 3 . 0 0}$.

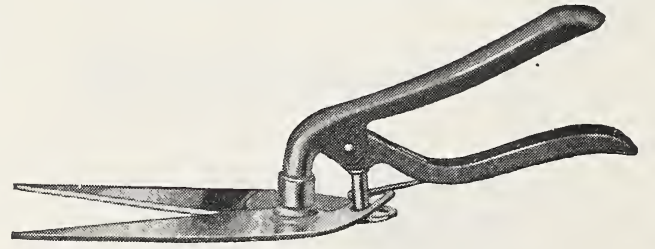

GOODWIN GRASS SHEARS

are made to cut grass. They're built to get around close corners easily with the buckles well up out of the way, and are easy on the wrist. The grip is natural. Ball bearin? action, blades sharpened enduringly from point to hilt. Price $\$ \mathbf{1 . 5 0}$.

\section{GRASWIP}

cut your grass and weeds the new way without stooping. It's like the swing of a golf stick; cuts with both forward and backward s wing. Price $\$ 1.00$. 


\section{WORCESTER}

\section{LAWN TESTED QUALITY MOWERS}

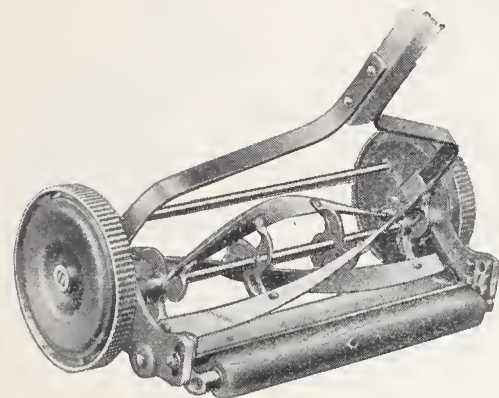

\section{TIP TOP}

The Tip Top is a universal favorite among light weight mowers of the plain bearing type. It is a sturdy, capable mower for the small lawn, and its general popularity stamps it as an excellent mower in its class. This mower is a three blade, low wheel, plain bearing machine, compact and well built of good materials, and is generally conceded to be the finest mower built in this competitive class.

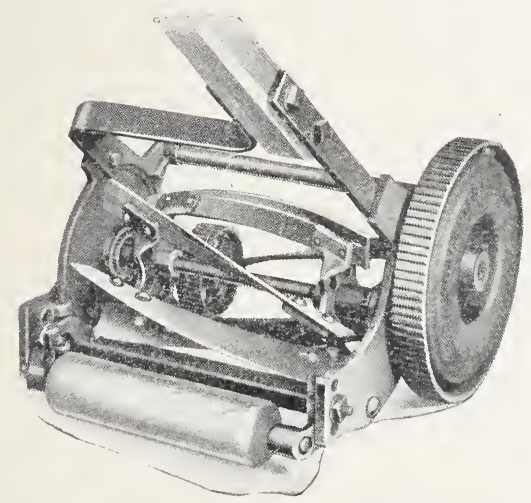

\section{Worcester Lawn Trimmer}

A thoroughly practical machine for trimming the edges of the lawn. This trimmer cuts a generous swath (ten inches) and is as carefully built and perfectly balanced as a fine grade lawn mower. It will not hobble or bump over the lawn as does the average trimmer, and it is so handy and practical a machine as to be almost indispensable for every lawn.

Built in ten inch size--eight inch wheelsfive blades-ball bearing.

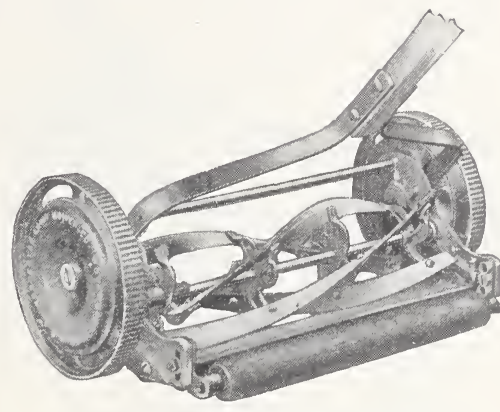

TIP TOP PRICES

12 Inch $\$ 4.98$

14 Inch $\$ 5.98$

16 Inch $\$ 6.50$

18 Inch $\$ 6.98$

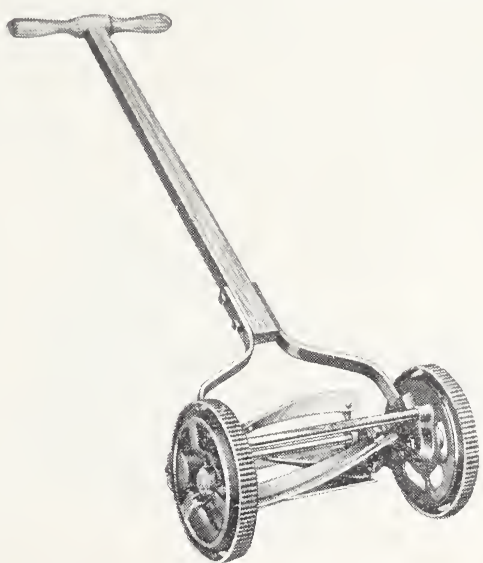

JUNIOR

The first real practical mower built for the younger generation. The handle and other details of this mower have been designed especially for the boy or girl from seven to twelve years of are. This machine is of the usual Worcester quality and will do excellent work. The Junior has eight inch wheels, three revolving knives, is equippped with ball bearings and is extremely light in weight. Childdren will enjoy mowing the lawn with a Worcester Junior. 


\section{WORCESTER}

\section{LAWN TESTED QUALITY MOWERS}

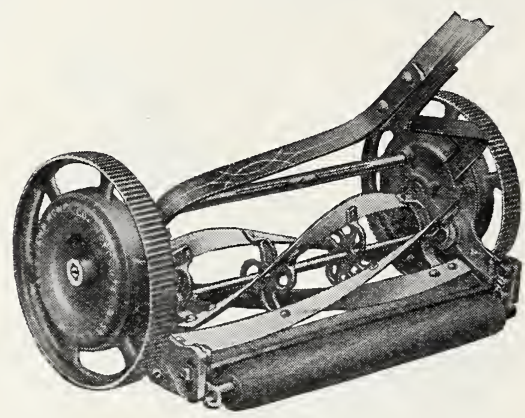

NEW WORCESTER

For those who have a rather large area of lawn there is no finer lawn mower than the New Worcester. The fact that this mower has long been a favorite in public parks and cemeteries all over the country testifies to its rugged construction and fine quality. It is well balanced and surprisingly easy to handle.

Ten inch wheels, large ball bearings, four blades, construction strongly reinforced.

\section{PRICES} 16 Inch
18 Inch $\$ 11.98$ $\$ 12.98$

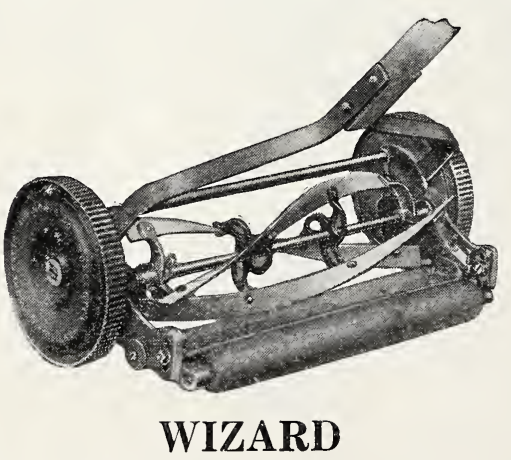

This mower is the practical mower for the average home owner. The wheels are a little smaller than on the New Worcester, and the mower is lighter. It is a very capable and strongly built mower that will give entire satisfaction on any lawn.

\section{PRICES}

12 Inch $\$ 7.25$

14 Inch $\$ 7.98$

16 Inch $\$ 8.25$

18 Inch $\$ 9.75$

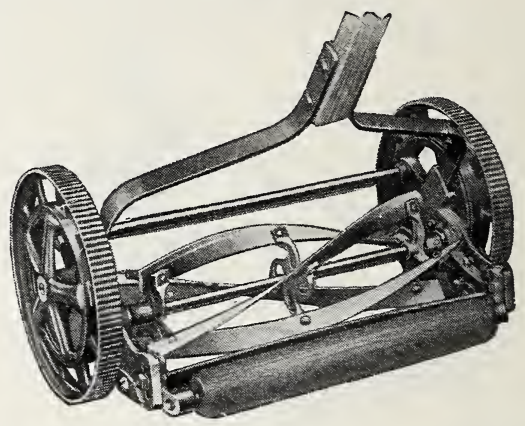

\section{HIGH WHEEL INVINCIBBLE}

The High Wheel Invincible features the open type of wheel, and is a very capable, high grade mower for general use. It is carefully constructed of the finest quality of materials and is well balanced and easy to push.

Ten inch wheels, four blades, trouble-proof bearings.

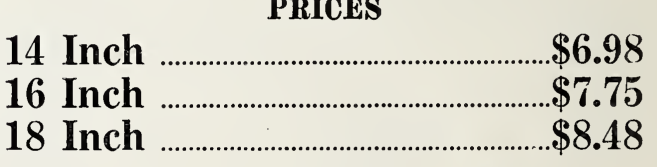

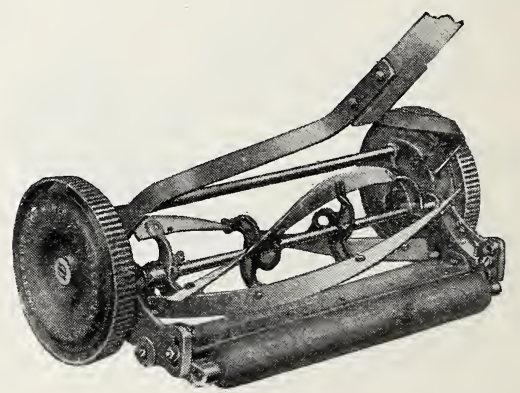

NEW ENGLAND

This is a low wheel light weight mower of the ball bearing style, suitable for the medium size or small lawn.

Built of good steel and including most of the features of the larger and more expensive mowers. The New England will give very good service and is a very popular type of mower.

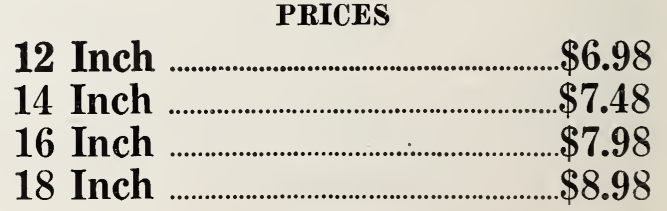




\section{ELM PARK-BALL BEARING} 14 Inch $\$ 9.48$ 16 Inch $\$ 9.9 \delta$

18 Inch $\$ 10.48$

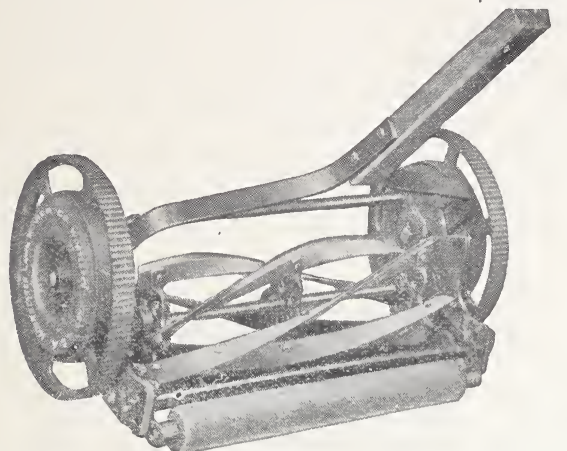

This mower has ten-inch wheels of the closed type and is consaructed with five reel blades to give a very clean, smooth appearance to the lawn. This mower is more adapted to an even lawn where the advantages of the five blades are more apparent. The Elm Park is a thoroughly high grade mower in every detail. The design and construction make it a very easy handling machine. The steel is of the very finest quality knife steel; the underknife with the lipped edge of course. The cones are the result of a year's experiment in the heat treating and grinding of different kinds of steels and these bearings will wear for an indefinite time. The brackets that support the wood roller are of tough malleable iron that will not bresk and are equipped with grass catcher hooks to accommodate the use of grass catchers if desired. These brackets are also equipped with ball bearing units to support the wood roller so that the roller spins freely and there will never be any tendency to drag. The handle is reinforced to prevent loosening. This machine may be guaranteed to give excellent service.

\section{INTERNATIONAL B. B.}

14 Inch $\$ 12.98$

16 Inch $\$ 13.49$ 18 Inch $\$ 13.98$

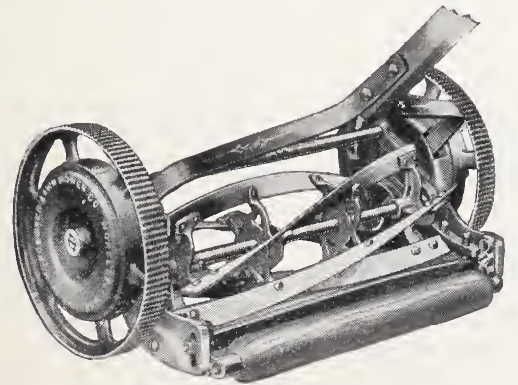

The International is designed and constructed along the lines of the New Worces- ter-as a heavy duty machine. It has five blades, however, and on a level, well-kept lawn it would be capable of giving a little better results than the New Worcester. The wheels and side plates of the Internationa are of a very fine grade iron designed to insure against breakage under practically all conditions. The knife steel is given special attention, both in regard to selection treatment. This machine is equipped with ur new malleable roller bracieis with ball bearing units as in the Elm Park. The reel shaft is extra heavy and of solid cold drawn steel. The cones and other parts of the bearings are of the very finest materials to insure long wear and freedom of trouble. This International is in every way a high grade mower and has in many instances replaced lawn mowers that sell at a considerably higher price.

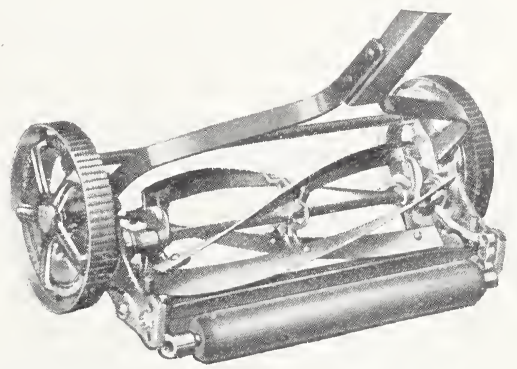

\section{NEW GRASSHOUND B. B.}

12 Inch

14 Inch $\$ 5.50$

16 Inch $\$ 6.48$ $\$ 6.98$

The New Grasshound featuies the open wheel style of mower that has recently come into wide popularity. This is a light weight but very sturdy machine and with its four blades is capable of very satisfactory work. The five ribbed spokes in the wheels give ample strength to these parts and the frame of the mower is so designed as to give rigid alignment of the knives under all conditions. The knife steel in this mower is a fine quality of steel and the underknife has a lipped edge fastened to the cutter bar with machine screws, which are characteristics of all Worcester lawn mowers. The bearings are trouble-proof and require practically no attention. For a light weight capable mower this New Grasshound will prove extremely popular.

\section{MASTER MOWER}

\section{Inch 18 Inch} $\$ 23.48$ $\$ 25.06$

The simplicity of the new patented application of Hyatt Roller Bearings eliminates all be ring trouble, insures lifetime service and positive alignment of knife units, and also supports Traction Wheel Studs and smooths the action of the Master Mower. Wear and friction are further eliminated by the use of Ball Bearings in roller hangers. 


\section{FOR THE PORCH AND LAWN}

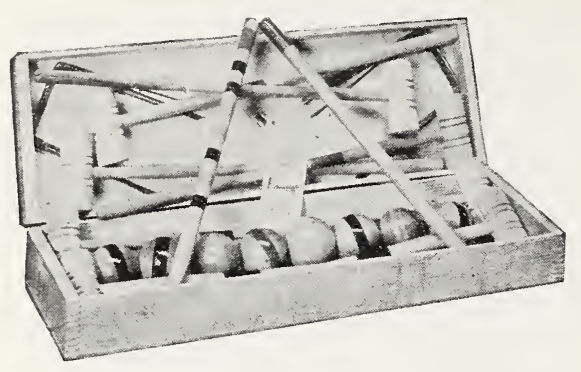

\section{CROQUET SETS}

From the finest hand turned, French Polish finished sets of unusual attractiveness and beauty produced for the most discriminating buyer, to the lowest priced sets that are good-all represent the greatest values that our unusual facilities, long experience has made it possible for us to sell.

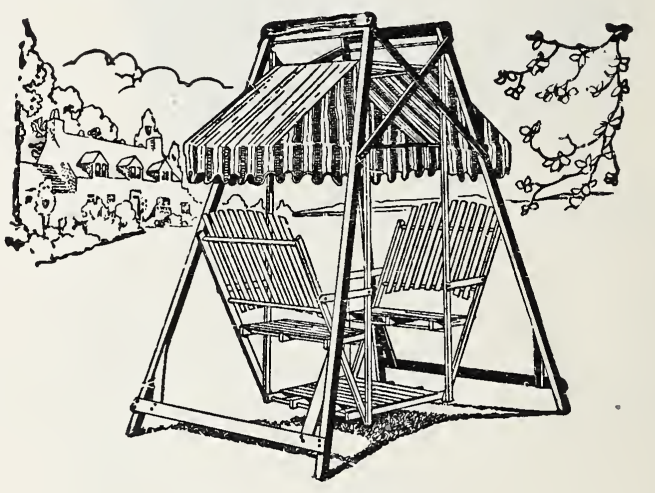

\section{LAWN SWING}

Four passenger model; selected hardwood stock; bolted construction throughout; frictionless, noiseless, long-wearing metal hangers, brackets and hooks (metal-to-metal); seats are adjustable. Frame in Red Enamel, seats and floor in Natura1 Varnish.

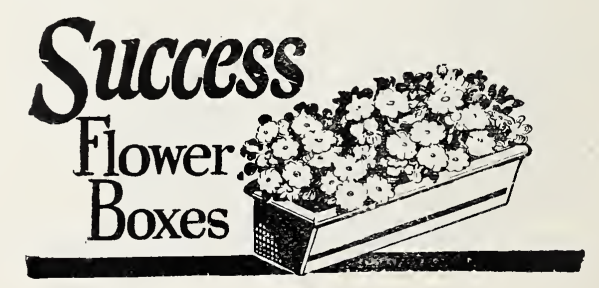

This box made with a patented self irrigating and

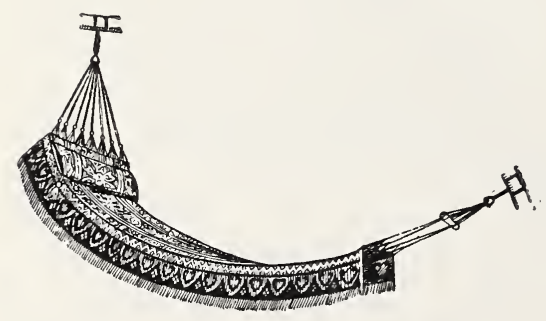

\section{PALMER'S HAMMOCKS}

Close canvas weave, with tastefully colored stripes. air circulating system of coppered steel with a lead coat which will neither rust nor deterlorate. 98e up.

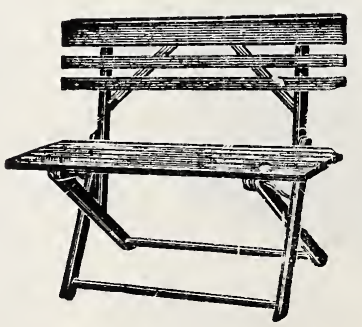

\section{LAWN SETTEE}

All hardwood, Natural Varnish finish; shaped seat, 5 slats; back, 5 slats; drive screw construction. The "Outstanding Value of the Season." 


\section{BIRD SUPPLIES}

\section{BIRD CAGES}

Imported, artificially decorated and colored cages in new finishes, beautifully blended in two-tone combinations of colors with hand painted bound glass guards.

Also plain brass throughout, white enamel tray, china cups, wire guard and swing.

\section{$\$ 2.50$}

\section{EGG IND FRUIT CANARY MLXTURE}

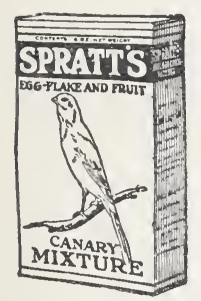

Totally unlike any other mixture prepared for regular canary feeding, Spratt's Egg: Fruit and Canary Seed Mixture offers the bird a delightful and wholesome change.

The quality of the European Canary Seed, sweet summer rape and other seeds forming the blend, is unsurpassed and the addition of egg-flake and fruit makes it perfect. Its regular use (alternated occasionally with Spratt's Cod Liver Oil Cage Bird Food) must result in improved beauty, health and song.

(OI) LIVER OII, CIGE BIRI) FOOI)

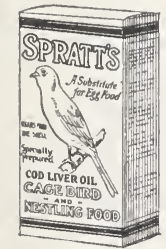

For feeding young birds and old birds in the moulting season. A tonic and flesh and bone maker. Unequalled as an ald to feather growth.

\section{SPRATT'S SONG RESTORER}

An invigorating tonic and treat for Canaries, Linnets, Gold-finches and seed-eating birds.

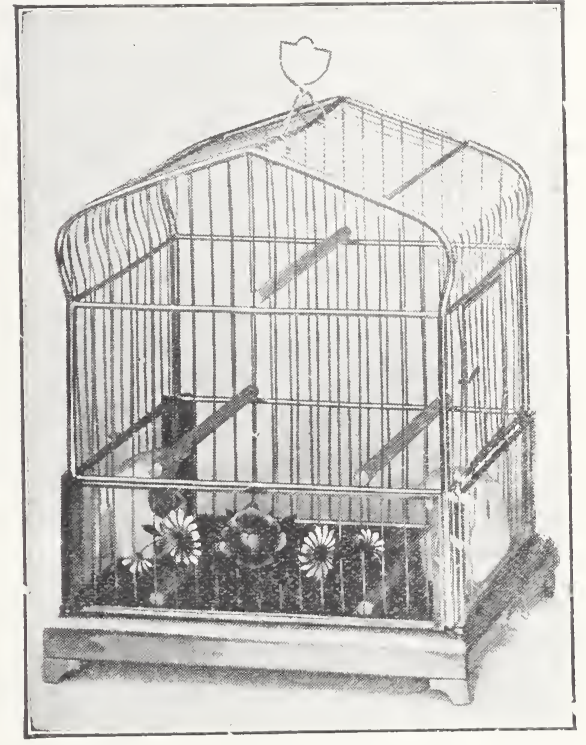

BIRI SEEI

Try our recleaned fresh bird seed if your canaries do not sing or thrive as they should: We have hundreds of bird fanciers who are getting results and are well pleased.

1 lb., 133 。

\section{SIRITI'S MOULTING FOOU}

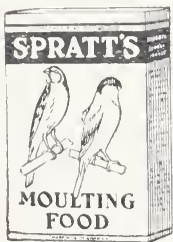

SPR I'T'I'S

"SING-SONG"

A n appetizing

food and pick-meup for all songsters.
It is not onry a valuable tonic mixture but a flesh and bone-making food, keeping birds in good health during the moulting period. As a

her producer, it is unrivaled.

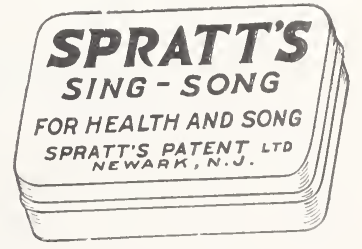




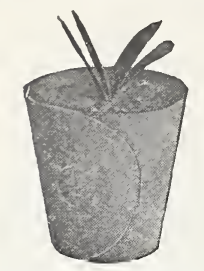

NEPONSE'T' PO'T

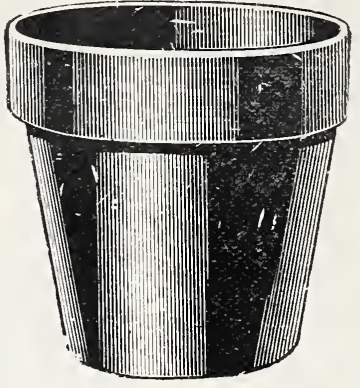

FLOWER PO'T

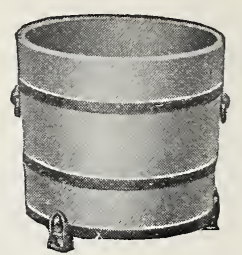

NEW YORK STILE

\section{FLOWER POTS AND FIBREWARE}

\section{Standard Earthenware Flower Pots}

Full inside measurements. Six at dozen rates; 50 at 100 rates; 500 at 1000 rates.

\begin{tabular}{|c|c|c|c|c|c|c|c|c|c|c|c|c|c|c|}
\hline Sizes & Each & Doz. & 100 & 1000 & Sizes & Each & Doz. & 100 & 1000 & Sizes & & Each & Doz. & 100 \\
\hline in & $\$ 00$ & $\$ 03$ & \$2 ? & & $3 \frac{1}{2}$ in & $\$ 0.07$ & $\$ 0.50$ & $\$ 3.00$ & $\$ 21.60$ & 8 in & ........... & $\$ 0.30$ & $\$ 3.00$ & $\$ 20.00$ \\
\hline 2 & & $\$ 0.3$ & & & 4 in. & .07 & .60 & 4.00 & 30.00 & 9 in & ............ & .40 & 4.00 & 30.00 \\
\hline 116 & .05 & .35 & 2.25 & 16.00 & in & .08 & .75 & 5.40 & & 10 in & ............. & .60 & 6.50 & 42.00 \\
\hline in. & .07 & .50 & 3.00 & 20.00 & $\begin{array}{l}6 \\
7\end{array}$ & $\begin{array}{l}.15 \\
.20\end{array}$ & $\begin{array}{l}1.50 \\
2.00\end{array}$ & $\begin{array}{l}10.00 \\
13.50\end{array}$ & $\begin{array}{r}72.90 \\
\ldots \ldots \ldots\end{array}$ & $\begin{array}{l}12 \text { in } \\
14 \text { in }\end{array}$ & 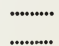 & $\begin{array}{l}1.10 \\
2.00\end{array}$ & $\begin{array}{l}11.00 \\
20.00\end{array}$ & $\begin{array}{r}82.50 \\
135.00\end{array}$ \\
\hline
\end{tabular}

\section{Earthenware Flower Pot Saucers}

\begin{tabular}{|c|c|c|c|}
\hline Sizes & Each & Doz. & 100 \\
\hline 4 in. & $\$ 0.04$ & $\$ 0.30$ & $\$ 2.50$ \\
\hline 5 in. & 04 & .40 & 3.00 \\
\hline 6 in. & 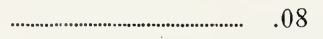 & .75 & 5.00 \\
\hline $7 \mathrm{in.}$ & - & .90 & 6.50 \\
\hline 8 in. & $\ldots \ldots \ldots \ldots \ldots \ldots \ldots \ldots \ldots . . . \cdots$ & 1.50 & 10.00 \\
\hline 9 in. & - & 1.50 & 1125 \\
\hline $10 \mathrm{in.}$ & .20 & 1.75 & 13.50 \\
\hline $11 \mathrm{in.}$ & .25 & 2.25 & 1650 \\
\hline 12 in. & 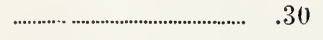 & 2.75 & 20.25 \\
\hline 14 in. & 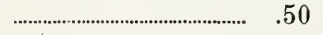 & 5.00 & 35.00 \\
\hline
\end{tabular}

\section{Neponset Waterproof Paper Flower Pots}

Made of a tough, waterproof paper that retains moisture very satisfactorily. Testing under actual growing conditions has proven that this container may be used successfuily when seedling plants are grown therein 6 to 8 weeks.

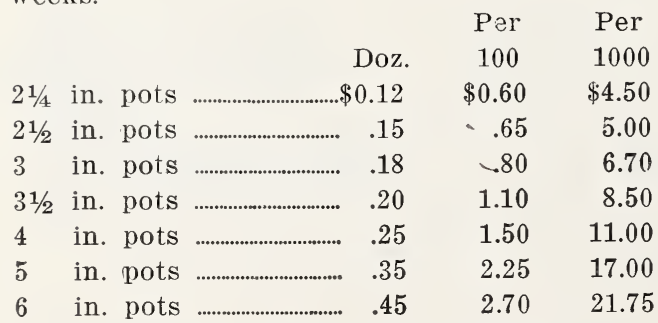

Send for Circular and Sample

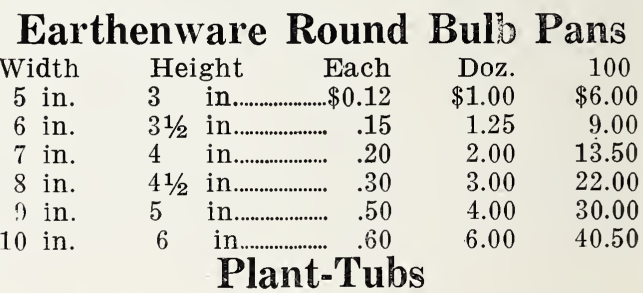

New York Cedar. Made of the choicest seasoned cedar, highly finished with black hoops; will last twice as long as cypress.

No. Diam. Ht. PriceNo. Diam Ht. Price 112 in. $10^{1 / 2}$ in. $2.983 \frac{1}{2} 16^{1 / 2}$ in. $151 / 4$ in. 5.48 213 in. 13 in. $3.754 \quad 19 \frac{1 / 2}{2}$ in. 17 in. 5.98 $314 \frac{1}{2}$ in. 15 in. $4.255 \quad 22 \frac{1}{2}$ in. $181 / 2$ in. 7.98

\section{Tree Tubs}

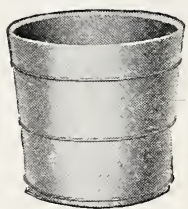

RICHMOND STYLE
Made of seasoned, selected Virginia White Cedar; bound with electric-welded wire hoops (galvanized), three hoops to each, except the smallest two tubs which have twe.

\begin{tabular}{cccr}
\multicolumn{2}{c}{ STYLE } & Inches \\
Top Diam. & $\begin{array}{c}\text { Inches } \\
\text { Depth } \\
\text { Inside }\end{array}$ & $\begin{array}{r}\text { Price } \\
\text { Each }\end{array}$ \\
No. & Inside & 7 & $\$ 0.70$ \\
2 & 7 & 8 & .75 \\
3 & 8 & 9 & .80 \\
4 & 9 & 10 & .90 \\
5 & 10 & 10 & 1.15 \\
6 & 11 & 11 & 1.35 \\
7 & 12 & 12 & 1.50 \\
8 & 13 & 13 & 2.00 \\
9 & 14 & 14 & 2.50 \\
10 & 15 & &
\end{tabular}




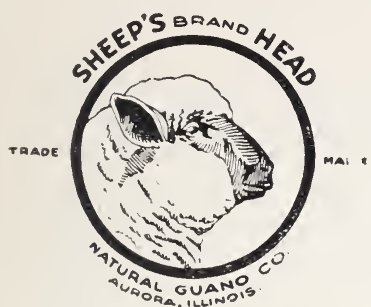

\section{SHEEP'S HEAD \\ PULVERIZED \\ SHEEP MANURE \\ FEEDS THE WHOLE PLANT}

No plant food has ever been found to take the place of natural manure as a complete fertilizing agent. Phosphate fertilizers develop the leaves. Potash fertilizers develop the roots. Another vital element to virile growth is necessary, ORGANIC MATTER! Sheep's Head Pulverized Sheep Manure contains organic matter-phosphoric acid, potash, nitrogen, and all the other ingredients essential to balanced, vigorous plant development.

Its use cannot be harmful to the plant life at the hands of the ordinary individual because its elements are in the natural fertilizing form.

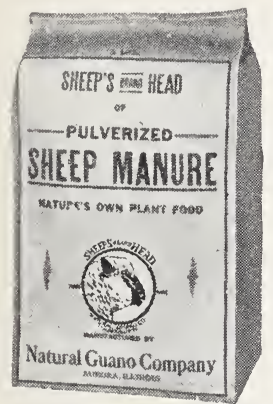

Lawns, Flower Beds, Flower Boxes, Vegetable Gardens, Grape Vines, Berry bushes, Fruit Trees, Shrubs, Rose Bushes, Nursery Stock, Shade Trees, Field Crops, Cemeteries, Golf Courses, I'arks

\section{Grow Quickly Beautiful, Luxuriant, Sturdy- When Their Soil Is Dressed With Sheep's Head Pulverized Sheep Manure}

2-pound

In Neat Packages

5 -pound

10-pound

$\begin{array}{ll}. .9 & .25 \\ . . & .40 \\ . & .75\end{array}$

25-pound

$\$ 1.25$

200

50 -pound

3.00

"Igricu" Fertilizer contains all the elements of plant food which have long been regarded as essential to the fertilization of growing crops, as well as other elements which have not been so generally recognized. The finest for general trucking. Analysis 5-10-5. 100 1bs., \$4 00 ton, $\$ .00 .00$.

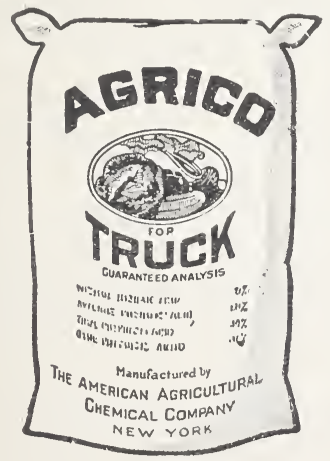

Youarch. A high zrade fertilizer for all crops. Analysis 4-8-4. 100 lbs., \$3.00; ton, $\$ 45.00$ 。

Champion. Special fertilizer for plants that require a high per-

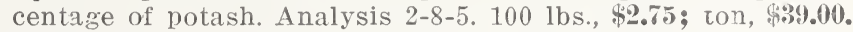

super Phosphate. This is one of our fertilizers which is used in the largest quantity in most mixtures as a base. Analysis 16\% Available Phosphoric Acid. 100 lbs., \$2.25; ton \$29.00,

Bloomaid. Fifteen times as rich as manure. Very high analysis. The best fertilizer for flowers and shrubs. 25 lbs., \$1.25: 100 lbs., $\$ 5.00$,

Floranid (Urea). The most highly concentrated nitrogenous fertilizer in commerce, contains $46 \%$ of available nitrogen, and leaves no harmful residue in the soil. A quick-acting stimulant for lawns, vegetables, fruits and flowers. Allow 2 ounces per square yard in the garden, $1 / 2$ unce per square yard on the lawn; in the latter case it must mixed with foul tımes its bulk of fine soil or sand.

Lb., 25c; 5 lbs., 90c; 10 lbs., \$1.50; 25 lbs., \$2.75; 100 lbs.,

$\$ 9.00 ; 500$ 1bs., $\$ 12.50$.

Nitropluoska. Is a complete fertilizer containing $15 \%$ Nitrogen, $30 \%$ Phosphoric Acid, and $30 \%$ Potash, all available. Clean, odorless, and practically water-soluble. Can be used in vegetable and flower garden, seed-bed and for potted plants Lb., 25c; 5 lbs., 90c; 10 lbs., \$1.50; 25 lbs., \$2.75: 100 lbs., \$s: 500 lbs., $\$ 37.50$. 


\section{SOIL INGREDIENTS}

Aco. A culture of bacteria a sociated with the breaking down of organic materials. Add it to garden rubbish, leaves and grass clippings to hasten decay and quickly produce manure. 25 lbs., $\$ 2.00 ; 150$ lbs., $\$ 10.50$,

Ishes, Hardwood. These furnish potash. One to two tons per acre may be harrowed into land in winter or early spring. May be broadcast between rows of corn, potatoes, beets, carrots, etc. 10 pounds per 100 feet. 100 lbs., $\$ 2.00$; $1 / 4$ ton, $\$ 8.00$; $1 / 2$ ton, $\$ 15.00 ; 1$ ton, $\$ 25,00$.

Bone Meal. Animal bone is generally considered by experienced growers to be far superior, as a source of phosphoric acid for most crops, to the mineral phosphates. The analysis shows $4 \frac{1}{2} \%$ of ammonia with $23 \%$ total phosphoric acid, or $50 \%$ bone phosphate of lime. $25 \mathrm{lbs}$., \$1.25; $50 \mathrm{lbs}$, \$2.00; 100 lbs., \$3.50; ton, \$50.09.

Tankage. Similar in general effect to bonemeal, yielding lime and phosphoric acid. Used largely by the greenhouse man, and is excellent for grapevines. Allow 3 ounces per square yard ( 1,000 pounds to the acre) and rake in humus. $167 \mathrm{lb}$. bag, \$7.50; 1 ton, $\$ 80.00$.

Humus, Furnishes but little plant-food; highly valuable, however, as a soil ingredient, improving its texture and increasing its water-holding properties. May be used freely. $100 \mathrm{lbs}$. will cover 80 square feet 1 inch deep. 5 lbs., 25c; 10 lbs., 40c; 25 lbs., 75c: 100 lbs, $\$ 1.50 ; 1$ ton, $\$ 25.00$.

Lime, Agricultural Hydrated. Corrects acid conditions of the soil, and at the same time is a plant-food; further, it liberates other foods in the soil. Binds loose soils and curiously enough, opens heavy land. Quick acting. Use from 1 to 3 tons per acre; 6 to 18 ounces to the square yard. As a winter dressing to sweeten lawns, broadcast 1 ton to the acre or 6 ounces per square yard. 50 1b. bag, 75c.

Limestone, Pulverized, Slower to act than Hydrated Lime but the effect is felt over a longer period. Use from 2 to 4 tons per acre. 80 lb. bag, $\$ 1.00 ; 1$ ton, $\$ 15.00$. Specially favorable rates in carload lots.

Muriate of Potash. Excellent for potatoes, corn, grains, etc. Use from 350 to 750 pounds per acre. 50 lbs., $\$ 2.50 ; 100$ lbs., $\$ 4.50 ; 1$ ton, $\$ 65.00$ 。

Nitrate of Soda. A plant stimulant. Adds nitrogen in a form which is immediately available to the plants. Forces a heavy, succulent growth in lettuce and similar leaf vegetables. Gives a jump to lawns, and, in fact, to all crops. Use it sparingly and wtih great care. 1 lb., 12c; 5 lbs., 50c; 10 lbs., 90c: 25 lbs., \$1.75; 50 lbs., $\$ 3.00 ; 100$ lbs., \$5.00; 167 lbs., \$7.00; 1 ton, $\$ 75.00$.

Peat Fiber. A vegetable product which remains in the soil for many years without decaying; in the meanwhile it absorbs and holds it for the plants. Its presence in the top layer of a lawn adds materially to the resilient carpet-like feel of good turf. As a mulch around the roots of plants it is excellent. May be used freely. Large bale, about $170 \mathrm{lbs} ., \$ 4.00$.

Pulverized Poultry Manure. An excelient. fertilizer, ric in plant-food, for all garden crops, flowers, and lawns. Dig in 3 to 16 ounces per square yard, or $1 / 2$ to $2 \frac{1}{2}$ tons to the acre. Mix freely with soil or sand when applying to lawns and then use only very little. 100 lbs., $\$ 4.50 ; 500$ lbs., $\$ 17.00$; ton, $\$ 60.00$.

Salt, Agricultural. Occasionally used as a top-dressing for asparagus. Also effective as a weed-killer on roadways, paths, etc. 100 lbs., $\$ 2.00 ; 500$ lbs., \$9.00; ton, \$32.00.

Stim-U-plan'T. Fertilizer in tablets. These may be placed in the soil around plants, in fllower pots, or dissolved in water for a liquid ferailizer. 30 tablets, 25c, postpaid 30c; 100 tablets, 75c, postpaid 85c; 1,000 tablets, $\$ 3.50$, postpaid $\$ 3.65$.

Shredded Cattle Manure. A soil-builder and ideal mulch that is especially recommended for crops in hot, sandy soils. Also ideal for mulching perennial beds, asparagus, and peonies. Being organic, it releases plant food when needed, increases bacterial action, and adds humus.

Sulphate of Ammonia. A nitrogenous plant stimulant, very quick in action, tending to make soil acid. Increases leaf-growth, much used on lawns, which it not only feeds, but weeds are discouraged; when top-dressing lawns apply 1 ounce per square yard or 350 pounds to the acre, but first mix with several times its bulk of soil or sand. 5 lbs., 60c; 10 lbs., $\$ 1.00$; 25 lbs., \$1.75; 50 lbs., \$3.00; 100 lbs., $\$ 5.03$; 1 ton, $\$ 80.00$.

PLAN'TABBS are small, clean, quickly dissolving tablets without odor. Highly concentrated form of nitrogen, ammonia, phosphoric acid and potash in proper balance. Especially good inside where smelly fertilizer cannot be used, but equally effective on roses and other garden flowers. Pkg., 25c.

\section{STINUGERY}

Small Garden Unit. A composite culture of the bacteria essential for the growth of Peas, Beans, and Sweet Peas. 


\section{INSECTICIDES AND FUNGICIDES}

Pyrethrol. Will control most soft-bodied insects. Japanese Beetle, Rose Chafers, Lace bugs, potato bugs, aphis, cabbage worms, currant worms, white fly, thrips, cucumber beetle and many other types. 1/2 lb. tins, making 4 to 6 gals. finished spray, 50c: 2 lb. tins making 16 to 24 ;al. spray, \$1.o0; 10 lb. tins making 80 to 120 gal. spray, $\$ 6.00$.

int Destroyer. An effective remedy for Ants, $1 / 2$ teaspoonful required for each ant hill. 40c per can.

Aphisirogen. Makes a complete spray for most sucking insects; prepared especially for roses and other plants. Per 4 oz., Foc: 1/2 lb., \$1.25; 2 lbs., \$3.50; 12 lbs., \$15.00.

Arsenate of Lead, Powder. Superior to paste in that it does not deteriorate from standing Use 1 to $1 \frac{1}{2} \mathrm{lbs}$. to 50 gals. of water. 1 lb., 28c: 4 lbs., \$1.00: 10 lbs., \$2.25; 25 lbs., \$5.00; 50 lbs., $\$ 9.00$.

Black Leai 40, A concentrated nicotine solution for aphis, thrip and red spider. Dilute $1 \mathrm{oz}$. to from 3 to 6 gals. of water. 1 oz. bot., \$0.35; 5 oz. bot., \$1.00; 1 lb. bot., \$2.25; 2 lb. tin, \$3.25; 5 lb. tin, \$6.25; 10 lb. tin, $\$ 10.75 ; 50$ lb. drum at 95c. per 1b., \$47.000.

Bordeaux Vixture, Powder. Can be used dry or as a spray. When used as a spray $6 \mathrm{lbs}$. to 50 gals. of water will make standard 3-3-50 mixture. 1 lb., 3oce; 4 lbs., \$1.00; 10 lbs., \$2.25; 25 lbs., $\$ 5.00 ; 50$ lbs., \$9.00。
Tobacco preparations, either dust or liquid or both, is for sucking and soft bodied insects. It will be wasted on disease and hard-shelled insects. Sulphur for garden work. You will need it for mildews. Lime will prevent damage by slugs and snails. Lime-sulphur solution is necessary for scale insects on trees and shrubs. Miscible oils are good for winter spraying on these same insects, but injure foliage in spring. Either lead arsenate, calcium arsenate or paris green is needed for beetles, caterpillars and other insects that chew and swallow pieces of foliage. For small gardens a small package of each will be necessary. Any surplus (except for lime) will be good for several years.

Grape Ioust. Powder. A remedy for mold and mildew. Ready for use as bought. 5 lbs., \$1.00; 10 lbs., $\$ 1.80$ 。

Insectrogen. A complete spray. Poison, fungicide and fertilizer. Highly effective for leaf chewing insects, and an equally efficient detergent for black spot on roses, and mildew and Red Spider on Phlox. Half pints, $\$ 1.00$; pints, $\$ 1.75$ : quarts, \$2.75; half gallons, \$4.50: gallons $\$ 8.00$. (Not mailable)

herosene Emulsion for Caterpillars, Price, 1 qt., 75c: 1 gal., $\$ 2.00$.

Bordeanx Irsenate of Lead. Powder. Use 7 lbs. to 50 gals, of water. 1 lb., 50c; 4 lbs., $\$ 1.75$

Hammond's Copper Solution for Mildew and Blight. Price, 1 qt., \$1.25; 1 gal., \$4.50.

Cyanogas, "Calcium Cyanide," Grade A, for the destruction of ground moles, wood chucks, rats and other rodents. Per lb., $\$ 1.00 ; 5$ lbs., \$3.00. (Not mailable.)

Evergreen. Destroys a great number of both chewing and sucking insects without danger of burning the plants. I oz. bottle, 35c; 6 oz. bottle, $\$ 1.00$; pint, $\$ 2.00$; quart, $\$ 3 . .00$ : gallon, $\$ 11.50$; 5 gallons, $\$ 4500$.
Lemon 0il. Effective against scale and aphis. Particularly recommended for use indoors, since it as a pleasant odor. Dilute 1 part to 10 parts of water. $1 / 2$ pt.. 45c: 1 pt., 75c: 1 qt., \$1.25: 1 gal., \$3.00: 5 gals. $\$ 12.00$ 。

Lime Sulphur Solution. The standard remedy for scale and for certain fungus. Use 1 part to 9 parts of water. 1 qt., 50c; 1 gal. $\$ 1.00$ : 5 gal., $\$ 3.75$; $1 / 2$ bbl., 25e gal.; 1 bbl., 220 gal.

Lime Sulphur. Powder. Apply 12 to 15 lbs. in 50 gals. of water. 1 lb., $39 c ; 5$ lbs, $\$ 1.25 ; 10$ lbs., $\$ 200: 25$ libs., $\$ \frac{1}{2000 ;} 10 n$ lbs., \$13.00。 
Nico Fume. Liquid. An effective vaporizing liquid. 1/4 lb., 85̌c; 1 lb., \$2.00; 4 lbs., \$อ.85. 8 lbs., \$10.85.

Pomo-Green. With nicotine. The leaf green all-in-one dust or spray. 1 lb., 75c; 5 lb. can, $\$ 3.00$.

Para-Dichlorobenzene. Highly recommended for destroying the peach borers in trees four years and older. During September a ring of the crystals is placed on the soil around the trunk and covered by mounding the earth against the tree. One ounce is sufficient for each tree. $1 \mathrm{lb}$. can, 60c.

Paris Green. 1/4 1b., 15c; 1/2 1b., 30c; 1 lb., ö0c,

PYROX (Bowker's). The one best and safest all-around spray which kills all leafeating insects and prevents blight and all fungous troubles, without injury, on trees, grape-vines, currant bushes, potatoes, cantaloupes, cucumbers, and other garden vegetables, also on rose bushes, shrubbery, etc. It is a creamy paste which looks like paint and "sticks like paint." It needs only to be mixed with cold water and it is ready to apply. 1 lb., 50c; 5 lbs., \$1.75; 10 lbs., \$3.00; 25 lbs., \$6.25; 50 lbs., \$10.75; 100 lbs., \$15.50; 300 lbs., $\$ 43.50$.

Scalecide. Used for the destruction of the San Jose scale. Dilute at the rate of one gallon to twenty gallons of water. Scalecide does not clog nozzles, hose or pump, and is pleasant to use. Trees may be sprayed in winter and early spring before they start to come to bud. 1 qt., 70c; 1 gal., \$1.60; 5 gals., \$6.00; 10 gals. $\$ 10.00$ : 15 gals., \$13.50; 30 gals., $\$ 22.50$; 50 gals., 28.00 ,

Semesan. A Mercuric Disinfectant. As a remedy for the malignant grass disease called "Brown Patch," Semesan has been successful, spectacularly so., and is now used throughout the country, both to prevent and cure attacks of this parasite on golf-courses, turf tennis-courts, baseball diamonds and estate lawns. 2 oz., 50c.; $1 \mathrm{lb}$., \$2.75; 5 lbs., \$13.00; 25 lbs., \$56.25; 100 lbs., $\$ 220.00$.

Semesan Bel. Applied to whole or cut seed potatoes, either as a dry powder or a whitewash-like water mixture, Semesan Bel will prevent or control the common seed-borne potato diseases. 4 oz., 50c; 1 lb., \$1.75; 5 lbs., \$8.00; 25 lbs., \$31.25; 100 lbs., \$120.00.

Slug Shot. One of the most known remedies for cabbage and currant worms. Apply as bought. 1 lb., 20c; 5 lbs., 60c.
Snarol. An effective bait for controlling Cutworms, Grasshoppers, Snails, Slugs and Sow Bugs. Not injurious to plants or other vegetation. $1 \mathrm{lb}$, 35c; $3 \mathrm{lbs}$., 95c; 15 lbs., \$3.00; 50 lb. sack, $\$ 8.00$. (Not mailable.)

Soap. Fish Oil, or Canstic Potash Fish 0il. Remedies for scale and aphis. 1 lb., 30c; 5 lbs., \$1.25; 25 lbs., \$4.00; 100 lbs., \$13.00.

Sulphur. Powdered. For mildew. 1 lb., 15้c; 5 lbs., 69c; 10 lbs., $\$ 1.00 ; 100$ lbs., $\$ 6.00$.

Suphur Candles. For fumigating the conservatory and greenhouse, also the sickroom. Each, 10c; per doz., \$1.00.

Thrip Juice (Hammond's). Very effective against aphis, red spider, mealy bug, etc. Qt., \$1.35; gal., \$4.25.

Tobacco Dust. The best of the Tobacco Dusts, for dusting or fumigating. $1 \mathrm{lb}$., 25c; 5 lbs., 60c; 10 lbs., \$1.00; 25 lbs., $\$ 2.00 ; 50$ lbs., $\$ 3.75 ; 100$ lbs., $\$ 6.00$.

Tree Tanglefoot. A paste preparation for painting around the trunks of trees, in the form of a band. Caterpillars and other crawling pests cannot get over it. $1 \mathrm{lb}$., 60c; 5 lb. can, $\$ 2.75 ; 10$ lb. can, $\$ 5.25 ; 25$ lbs., \$11.00.

Tree Wound Paint. Prevents decay. A residium, penetrating, antiseptic paint that is not affected by heat, cold or moisture. Does not peel, crack or get brittle. Stops tree bleeding. Pt., 60c; 1 qt., $\$ 1.00 ; 1$ gal., \$3.50.

Volck. A refined oil emulsion that may be used on foliage with entire safety. Effectually controls scale, mealy bug, white fly, red spider, aphids, thrips, etc. Does not discolor foliage, but rather imparts a bright glossy appearance. One gallon makes from 32 to 100 gallons of spray solution. Half pt., 50c; pt., 75c; qt., $\$ 1.00$; gal., $\$ 3.00$; 5 gals., $\$ 12.00$.

Wilson's Weed Killer. Kills all plant growth. Dilute 1 part to 40 parts of water. Applied with an ordinary watering can. 1 qt., 50c; $1 / 2$ gal., 85c; 1 gal., $\$ 1.50 ; 5$ gals., $\$ 5.50$.

Wilson's 0. K. Plant Spray. An insecticide that is equally good upon house plants as well as in the garden. It will destroy aphis, red spider, lace wing fly, currant worms, and other soft-bodied insects. $1 / 2$ pt., 45c; 1 qt., $\$ 1.00$; 1 gal., $\$ 3.00$; 5 gals., $\$ 12.00$.

Zenoleum. A coal-tar product that is a powerful disinfectant, deodorant and germs destroyer. For use in stables, poultryhouses, dog-kennels, etc. 1/2 pt., 35c; qt., 75c; $1 / 2$ gal., \$1.25; gal., \$1.75; 5 gals., $\$ S$. 


\section{Foreign Names of Vegetables and Herbs}

\section{ENGLISII}

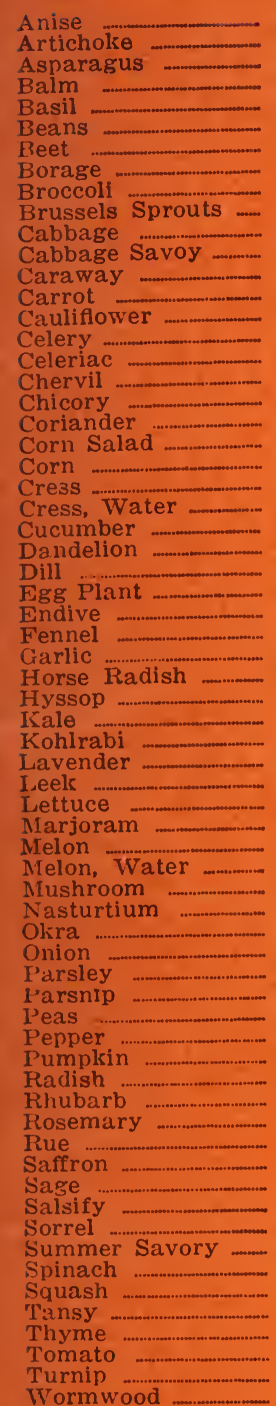

\section{GERMAN}

Anis, Grvener

Arrischocke -
Citronen Melisse Basilikum Melisse Bohnen Ruebe

Boretsch

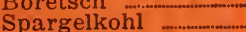

Roseukohl

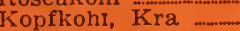

Wirsing

Feld Kuemnel

Carroten, Moehren

Blummenkohl

Sellerie

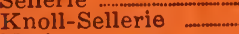

Kerbet

Chiceorien Wurzel -

Coriander

Feldsalat

Mais

Garen Kresse .....................

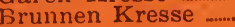

Gurken

Loewenzohe

Dille

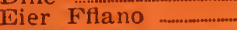

Endiven

Fenchel

Meer Rettig

Isop

Blaetterkohl ...........-...-

Knolkohl

Lavendei ...

Porre Lauch ............

Marjoram

MLelone

Wasser-Melone ......

Schwamm

Kupuciner Kresse.....

Ocher

Zwiebel

Zatersille ………….......

Pastinake

Erbsen

Melonen Kuerbiss.....

\section{Radies}

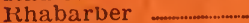

Rosmarin

Raute

Safran

Haferwurzel

Sauerampfer

Bohenkraut

Spinat

Kuerbijs

Gemeiner-rainfarn -

Thymian

Liebessapfel

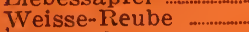

tVermuth

FRENCH

ITALIAN

Anis

Artichaur

Asperge -..........

Melisse citronelle. Basilic grand Haricots

Betterave

Bourrache

Chou de Bruxelles

Chou pomme

Chou de Milan

Chou des pres

Carotte

Chou-fleur

Celeri

Celeri-rave -.....-

Cerfeuil

Chicoree sauvage .

Corianare

Mache

Mais ........

Cressondefondtaine

Concombre

Concombre

Pissenlit

Aubergine

Cicoree-Endive

Ali

Panifort sauvage --

Hyssope

Chou-vert

Chou-rave

Lavende

Poureau

Marjolain

Melon

Melon d'eau

Champignon

Capucine

Gombeud

Ognon

Panais

Pois .

Piment

Potiron

Radis

Romarin

Rue

Safran - - -

Sauge

Salsifis

Oseille

Sarriette annulle ...

Epinard

Courge

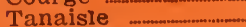

Thym d'Ammour

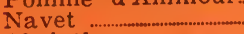

Absinth aso, Anacio

Anaso, Anacio _Sparagio

Mellissa

Basilico

Fagiuoli -........-

Barbabietola -

Boragine

Cavol brocolo

Cavolo agermaglia..

Cavolo cappuccío -

Lavalo di Milano....

Carvi

Carato

Covolo-flore -

Sedano

Se ana rapa

Cerfoglio

Cicoria Wselvatica.

Coriandorio

Valeriana

Agretto

Nasturzio

Cotriolo

Dente ar leone -

Aheto

Pentonciano ….............

Indivia

Finnochio - - -

Agho

Rafano _-

Issopo

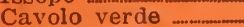

Cavolo rapa

Lavada

Porro

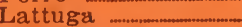

Maggiorana .............

Popone

Cocomera

Fungo pratajole -...

Nasturzio _.....

Ibisco

Cipollo

Prezzemolo

Pastinaca

Pisello

Peperone ....................

Zucca

Ravanello

Rabarbaro

Rosmorino

Rafferano

Salva

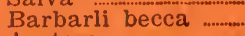

Aeetosa

Santoreggia - - - -

Spinnaccio

Zucca

Atansia

Timo

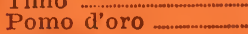

Navone -...................

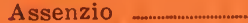

\section{HOLLAND}

Anijs

Artisjok

Aspersio -

Citroen Melisse -

Bconen m-

Bieten

Spruitkool

Slutkool

Savooikool _-m-m

Kavoolkool -

Karvij

Wortejen

Seiderij

Knoise erji -

Kervil ㄴ.

Korlander _-...-

Velesia ㄴ..-

Tunkers

Waterkers

-

Andijive

Nedkel

Knollook

Knollook -_.

Peperwortel

Hijsoop

Boerkool

Koolrabi ……

Prei -

Kropsia

Marjolijn

Meleon

Kampernoelle

Capucine-Kers …

Cl Uien …..................

Peterselit $=$

Pinksternadel - '...

Erwten ....................

Spaansch Peper

Radijs

Rabarber

Rosemarijn …..............

Mijnault

Salie …-

Zuring …_-

Boonenkruid ….....

Spinazio

Pompeon

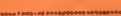

Tijm

Tomaat _-

Sulkerij

\section{PLANTING CALENDAR}

FEBRUARY - Sow in Hot Bed. Early Beans, Cabbage, Cauliflower and Celery, Carrot, Brocoll, Cucumber, Lettuce, Parsley, Radish, Tomato.

MARĆ - Sow in Hot Bed. Early Beets, Bealls, Cabbage and Carrots, Brocoli, Brusseis Sprouts, Cauliflower, Celery, Cucumber, Egg Plant, Kohlrabi, Lettuce, Melon, Parsley, Peas, Pepper, Radish, Tomato. Plant in Open Ground. Beet, Early Cabbage, Carrot, Cress, Lettuce, Onion, Peas, Radish, Round Spinach, Early Turnip, Potatoes, Onion Sets, English Beans.

APRIL-Sow in Hot Bed. S'weet Corn, Cucumber, Egg Plant, Melon, Pepper, Squash, Tomato. Plant in Open Ground. Asparagus, Beets. Brocoli, Brussels Sprouts, Early Cabbage, Carrot, Cauliflower, Celery, Cress, Kale, Kohlrabi, Lettuce, Melon, Onion, Parsley, Peas, Radish, Round Spirach, Turnip, Sage, Potatoes, Top Onions.

MAY-Plant in Open Ground. Asparagus, Beans, Beets, Brocoli, Brussels Sprouts, Late Cabbage, Carrot, Cauliflower, Celery, Sweet Corn, Cress, Cucumber, Kale, Lettuce, Melon, Okra, Onton, Parsley, Parsnip, Peas,

JUNE-Plant in Onen Ground. Lima Beans, Teets, Brocoli, Brussels Sprouts, Cabbage, Carrot, Sweet Corn, Cress Cun in Open Ground. Lima Kohlrabi, Lettuce, Nasturtium, Okra, Peas, Potatoes, Parsnip, Radish, Salsify, Spinach, Squash, Ruta Baga, Melon, Herbs.

JULY-Plant in Open Ground. Beans, Beets, Cauliflower, Celery, Carrot. Sweet Corn, Cress, Cucum-

ber, Late Cabbage, Kale, Kohlrabi, Nasturtium, Okra, Peas, Parsnip, Winter Radish, Spinach, Ruta Baga. AUGUST-Ilant in Open Ground. Bush Beans, Late Celery, Late Cabbage, Cucumber, Lettuce, Peas,

Radish. Spinach. Turnip.

SEPTEMBCF-Flant in Open Ground. Cabbage, Cauliflower and Lettuce for Wintering in cold

frames; Asparagus, Celery, Kale, Miustard, Winter Radish, Spinach, Turnip. 

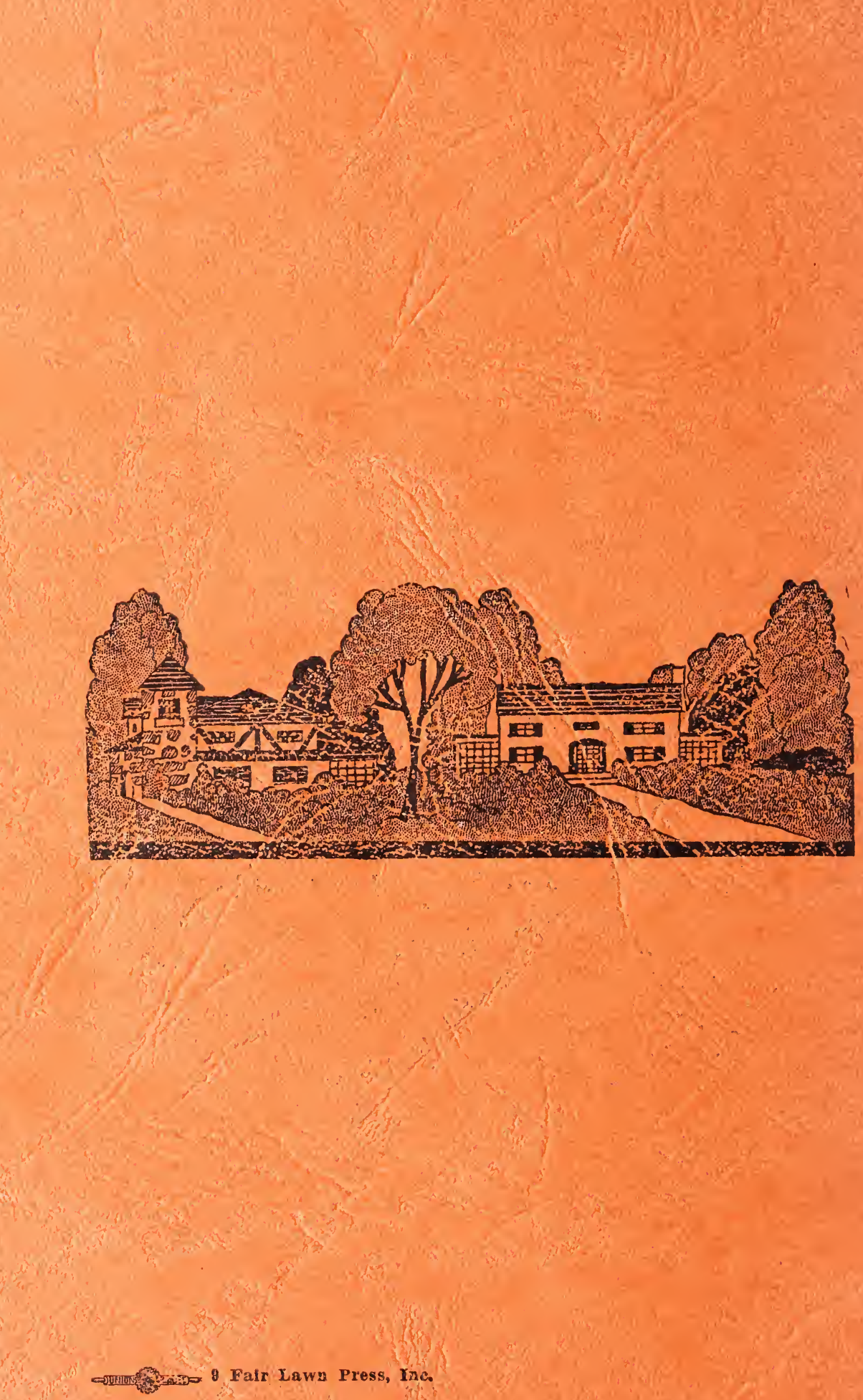